Georgia State University College of Law

Reading Room

Faculty Publications By Year

Faculty Publications

$1-1-2012$

\title{
Patents vs. Statutory Exclusivities in Biological Pharmaceuticals - Do We Really Need Both?
}

Yaniv Heled

Georgia State University College of Law, yheled@gsu.edu

Follow this and additional works at: https://readingroom.law.gsu.edu/faculty_pub

Part of the Food and Drug Law Commons, Legislation Commons, and the Science and Technology Law Commons

\section{Recommended Citation}

Yaniv Heled, Patents vs. Statutory Exclusivities in Biological Pharmaceuticals - Do We Really Need Both?, 18 Mich. Telecomm. \& Tech. L. Rev. 419 (2012).

This Article is brought to you for free and open access by the Faculty Publications at Reading Room. It has been accepted for inclusion in Faculty Publications By Year by an authorized administrator of Reading Room. For more information, please contact mbutler@gsu.edu. 


\title{
PATENTS VS. STATUTORY EXCLUSIVITIES IN BIOLOGICAL PHARMACEUTICALS- DO WE REALLY NEED BOTH?
}

\author{
Yaniv Heled ${ }^{*}$
}

Cite as: Yaniv Heled, Parents vs. Statutory Exclusivities in Biological

Pharmaceuticals-Do We Really Need Both?,

18 MiCh. TeleCOMm. TeCH. L. REv. 419 (2012),

available at $\mathrm{http}: / / \mathrm{www} . \mathrm{mttl}$.org/voleighteen/heled.pdf

INTRODUCTION

I. STATUtory ExClusivities and Patents as

Mechanisms of Protecting and Advancing

TECHNOLOGICAL INNOVATION

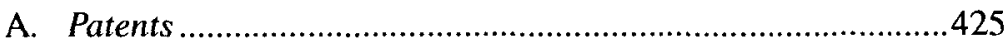

1. Patents as Incentive to Disclose...................................425

2. Patents as Incentive to Invent/Invest ..........................426

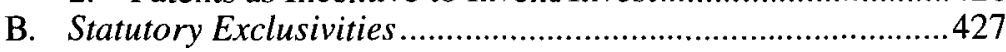

C. Patents and Statutory Exclusivities-

Similarities and Differences ...............................................440

II. The Regulation of Biologics in the United States .............433

A. The Approval of Biologics License Applications Under PHSA \$351.....

B. Regulatory Pathways for the Approval of Generic

Pharmaceuticals-Background

C. The Framework for the Approval of Generic Biologics Under the Biologics Price Competition and Innovation Act

III. Patents vs. Statutory ExClusivities IN BIOLOGICAL

Products: Timeline, Public Policy, and the

INTERESTS OF BIOLOGIC LICENSE HOLDERS

A. Patents vs. Statutory Exclusivities in Biologics:

A Timeline.

B. Patent Term vs. Market Exclusivity for Biologics:

A Case Study

C. Patents vs. Statutory Exclusivities for Biologics:

A Public Policy Perspective.

* Assistant Professor, Georgia State University College of Law; J.S.D. 2011, Columbia Law School; LL.M. 2004, Columbia Law School; LL.B. 2000, Tel Aviv University; Undergraduate Program in Biology 2000, Tel Aviv University. This Article concludes my J.S.D., and I wish to wholeheartedly thank Professors Harold Edgar and Gillian Metzger for their unfaltering support, advice, and mentorship throughout the project as well for their remarks on this Article. I am also grateful to Scott Hemphill, Bhaven Sampat, and Christal Sheppard for their insightful comments; to Goodwin Procter LLP, for granting me access to research resources; to Scott Warren for the helpful references; to Marisa Chan for invaluable research assistance; and to my wife, Danielle, for seeing this project through to its conclusion with me. 
1. Why Patents May Not Provide Sufficient Protection to the Interests of Developers of Biological Products

2. Why Concurrent Patent and Statutory Exclusivities Protection in Biological Products Might Have Undesirable Ramifications...

3. Biological Products Should Not Receive Concurrent Protection Under Both Patent Law and the Statutory Exclusivities Afforded Under BPCIA.

4. A Proposed Amendment to Limit Patent Protection Where BPCIA Statutory Exclusivities Are in Force........466

5. Why Patents Still Have a Role to Play in Incentivizing $R \& D$ in Biologics

IV. Statutory Exclusivities in Biological Products - A Peculiar Case or the Future OF INCENTIVIZING INNOVATION?

Conclusion

\section{INTRODUCTION}

Over the past decade or so, the United States has been the arena of a boisterous debate regarding the creation of a new regulatory framework for the approval of generic versions' ${ }^{1}$ of biologics-based pharmaceutical prod-

1. In this Article, the terms "generics" or "generic versions" will be used to refer to imitations and follow-on versions of already approved drug products, which are the subject of an application for marketing submitted to the FDA. Applications for generic versions of drug products typically attempt to rely on FDA findings of safety and efficacy reached as part of the FDA's review of the already approved version of the relevant drug product.

Notably, the term "generic biologics" in and of itself has spawned a considerable amount of controversy, as the nomenclature in the area of biologics seems to be perceived as dictating the discussion's results. See, e.g., Follow-On Protein Products: Hearing Before the H. Comm. on Oversight \& Government Reform, I10th Cong. 3 (2007) (statement of Janet Woodcock, M.D., Deputy Commissioner for Operations, Food, and Drug Administration), available at http://www.hhs.gov/asl/testify/2007/04/t20070326a.html [hereinafter Woodcock Statement] (addressing the issue of terminology and explaining why she prefers the term 'follow-on protein products'); Wendy H. Schacht \& John R. Thomas, Cong. Research Serv., RL33901, Follow-ON Biologics: INTEllectual Property and InNovation Issues, 3 (2008) [hereinafter 2008 CRS REPORT] ("many experts do not describe competing biologic products as 'generics,' as is the case for small-molecule pharmaceuticals; the term 'follow-on biologic' is commonly used instead"); Henry G. Grabowski, David B. Ridley, \& Kevin A. Schulman, Entry and Competition in Generic Biologics, 28 Managerial \& Decision Econ. 439, 449 n.l (2007), available at http://papers.ssrn.com/sol3/papers.cfm?abstract_id=992479 (asserting that while " $[\mathrm{t}] \mathrm{hroughout}$ the paper we refer to 'generic biologics' for the sake of symmetry with generic pharmaceuticals[,] [t]he term 'follow-on biologic' might be more appropriate ... given that the product might be required to complete clinical trials to demonstrate similar safety and efficacy to the originator"). The particular term used in the context of the new healthcare reform act to indicate that a product is an imitation of another already approved product is "biosimilar" (rather than "biogeneric," "generic biologic," "follow-on biologic," "generic biological product," etc.). However, given how innate the term "generic" has become 
ucts (also known as "biological products" and "biologics"2) ${ }^{3}$ - an important and increasingly growing class of drugs. ${ }^{4}$ The basic purpose of such a

to the legal discussion of regulated imitation-products, and its wide use in the context of drug law, in this Article I will use the term "generic" as mentioned above.

2. The FDA defines a biological product as "any virus, therapeutic serum, toxin, antitoxin, or analogous product applicable to the prevention, treatment or cure of diseases or injuries of man." Biological Products, 21 C.F.R. $\$ 600.3(\mathrm{~h})$ (2008). According to the FDA Center for Biologics Evaluation and Research (CBER),

[b]iological products include a wide range of products such as vaccines, blood and blood components, allergenics, somatic cells, gene therapy, tissues, and recombinant therapeutic proteins. Biologics can be composed of sugars, proteins, or nucleic acids or complex combinations of these substances, or may be living entities such as cells and tissues. Biologics are isolated from a variety of natural sourceshuman, animal, or microorganism--and may be produced by biotechnology methods and other cutting-edge technologies .... Biological products often represent the cutting-edge of biomedical research and, in time, may offer the most effective means to treat a variety of medical illnesses and conditions that presently have no other treatments available....

In contrast to most drugs, which are chemically synthesized and have a known structure, most biologics are complex mixtures that are not easily identified or characterized. Biological products, including those manufactured by biotechnology, tend to be heat sensitive and susceptible to microbial contamination.

What Are "Biologics" Questions and Answers, U.S. FOOD \& DRUG ADMIN., http:/www.fda.gov/AboutFDA/CentersOffices/OfficeofMedicalProductsandTobacco/CBER/u $\mathrm{cm} 133077$.htm (last visited Feb. 2, 2012) [hereinafter CBER FAQ]; see also Public Health Service Act, ch. 373, 58 Stat. $682 \$ 351$ (i) (1944) (PHSA) (codified at 42 U.S.C. $\$ 262(i)$ (2006)) ('the term 'biological product' means a virus, therapeutic serum, toxin, antitoxin, vaccine, blood, blood component or derivative, allergenic product, or analogous product ... applicable to the prevention, treatment, or cure of a disease or condition of human beings."). Accordingly, in this Article, I will use the terms "biologics" and "biological products" to refer to pharmaceutical products whose manufacturing involves the use of living organisms and will distinguish them from "small molecule drugs" (or "drugs" for short). For further discussion of the differences between biologics and small molecule drugs and the possible implications of these differences on frameworks for the approval of generic versions of biological products, see generally Biotechnology Indus. Org., The Difference with Biologics: The Scientific, Legal, and Regulatory Challenges of Any Follow-On Biologics Scheme, BIO, 6-8 (Apr. 25, 2007), http://www.bio.org/sites/default/files/WhitePaper.pdf [hereinafter BIO WHITE PAPER]; Donna M. Gitter, Innovators and Imitators: An Analysis of Proposed Legislation Implementing an Abbreviated Approval Pathway for Follow-On Biologics in the United States, 35 FLA. ST. U. L. Rev. 555, 560 (2008); Bryan A. Liang, Regulating Follow-On Biologics, 44 Harv. J. ON LEGIS. $363,367-78$ (2007).

3. See generally Tam Q. Dinh, Potential Pathways for Abbreviated Approval of Generic Biologics Under Existing Law and Proposed Reforms to the Law, 62 Food \& DRUG L.J. 77 (2007) (discussing the debate regarding the FDA's authority to create an abbreviated regulatory pathway for the approval of generic versions of biological products); Jeremiah J. Kelly \& Michael David, No Longer "If," But "When": The Coming of Abbreviated Approval Pathway for Follow-On Biologics, 64 FoOd \& Drug L.J. 115, 116 (2009) (reviewing the history of the debate over a U.S. regulatory scheme for the approval of generic biologics).

4. See generally 2008 CRS REPORT, supra note 1, at 1-2 (discussing the importance of biologics as a class of drugs); Robert J. Shapiro et al., The Potential American Market for Generic Biological Treatments and the Associated Cost Savings, 1-3 (2008), available at http://www.sonecon.com/docs/studies/0208_GenericBiologicsStudy.pdf 
framework is to create a fast and less-costly route to FDA approval for biologics that would be similar or identical to already-approved biological products-typically ones that are sold on the market at monopoly ratesthereby allowing cheaper versions of such medicines to enter the market. One of the main points of contention in creating the framework for the approval of generic biologics has been the length of the exclusivity period granted to developers of original biologics during which generic competitors are not allowed to enter the market. ${ }^{5}$ On March 21, 2010, as part of the

(describing the importance of biologics as a class of drugs, the growing numbers of biological products, important research done in the area of biologics, and their economic impact); Liang, supra note 2, at 363-64 (describing the prominence of biologics in the worldwide drug market). The importance of biologics lies in their structural and functional variety, which in turn embodies unprecedented therapeutic promise. Already, approved biologics include "wonder drugs" used to treat diseases and maladies that could not be treated effectively by smallmolecule drugs and in many cases used to be considered fatal. Examples of biologics include anti-cancer antibodies such as Herceptin and Avastin, anti-arthritis products such as Enbrel and Remicade, insulin products such as Humulin for the treatment of diabetes, erythropoietin products such as Procrit, clotting factor VIII for the treatment of hemophilia, and Aranesp for the stimulation of growth of red blood cells in people suffering from blood disorders such as anemia.

5. Since the imposition of competition on a previously monopolized market is expected to be accompanied by a drop in the price of the biological product, it is in the best interest of the monopolist to make its monopoly period last as long as possible. There are a variety of positions on the appropriate length of such periods of exclusivity. Different proposals over the past few years suggested setting the length of exclusivity period, in years, at 0 , 3 to $6,7,10,12$ to $12.5,12$ to $14,5,12$ to 15,13 to 16,17 , etc. See Biotechnology Indus. Org. (BIO), A Follow-ON Biologics Regime Without Strong Data Exclusivity Will. Stifle THE Development of New Medicines 1 (2007), available at http:/www.bio.org/ sites/default/files/FOBSData_exclusivity_20070926_0.pdf [hereinafter BIO DATA ExcLusIv1TY POSITION PAPER] (advocating a data exclusivity period for biologics of "no less than fourteen years"); Alex M. Brill, Proper Duration of Data Exclusivity for Generic BIOLOGICS: A CRITIQue 11 (2008), available at http://www.tevadc.com/Brill_Exclusivity_ in_Biogenerics.pdf (critiquing Grabowski's determination that the proper data exclusivity period should be 12.9 to 16.2 years and arguing that under a "more plausible set of circumstances" the proper data exclusivity period should be around 10 years); Gitter, supra note 2, at 615-16 (reviewing different positions on the length of the exclusivity period that should be afforded to original biological products); Henry Grabowski, Data Exclusivity for Biologics: What Is the Appropriate Period of Protection?, 10 Am. ENTERPRISE INST. FOR PUB. POL'Y Res. Health POL'y Outlook, Sept. 2009, at 1, http://www.aei.org/files/2009/09/08/10-HPOGrabowski-Sep08-g.pdf [hereinafter Grabowski 2009] (reiterating the author's position, as expressed in previous articles, that the minimum period of exclusivity should be set at twelve years); Henry Grabowski, Follow-On Biologics: Data Exclusivity and the Balance Benveen Innovation and Competition, 7 Nature Reviews Drug Discovery 479, 486 (2008) [hereinafter Grabowski 2008] (advocating a data exclusivity period of 12.9 to 16.2 years); LAURENCE J. Kotlikoff, Stimulating Innovation in the Biologics Industry: A Balanced ApPROACH TO MARKETING Exclusivity (Sept. 2008), available at hitp://people.bu.edu/kotlikof/ New\%20Kotlikoff\%20Web\%20Page/Kotlikoff_Innovation_in_Biologics21.pdf (arguing that granting developers of original biologics exclusivity periods of twelve to fifteen years would create overly long monopoly periods that would distort the economy of pharmaceuticals and calling for limiting exclusivity periods in biologics to lengths such as those granted under the Hatch-Waxman Act); Teva Discusses Follow-On Biologics, Initiatives for 2009, 8 Drug INDUS. DAILY (Feb. 2009) (discussing Teva's call for a seven-year exclusivity period); John A. 
healthcare reform act, Congress settled this debate by enacting the Biologics Price Competition and Innovation Act of 2009 ("BPCIA"), which provides statutory exclusivity ${ }^{6}$ periods of 12 to 12.5 years for original biologics from the date of FDA approval. ${ }^{7}$ This 12 - to 12.5 -year statutory exclusivity period

Vernon, Alan Bennett, \& Joseph H. Golec, Exploration of Potential Economics of Follow-On Biologics and Implications for Data Exclusivity Periods for Biologics, 16 B.U. J. SCI. \& TECH. L. 55, 56 (2010) ("[T]here should be 17 years of data exclusivity for new biologics."); Henry Grabowski \& Joseph DiMasi, Biosimilar, Data Exclusivity, and the Incentives for Innovation: A Critique of Kotlikoff's White Paper 4-5 (Duke Univ. Dep't of Econ., Working Paper No. 2009-02, 2009), available at http://econ.duke.edu/Papers/PDF/FinalDraft2_5_09.pdf (criticizing Kotlikoff's argument against granting a twelve- to fifteen-year data or exclusivity period) [hereinafter Grabowski \& DiMasi 2009]; Henry Grabowski, Genia Long, \& Richard Mortimer, Data Exclusivity Periods for Biologics: Updating Prior Analyses and Responding to Critiques 2, 30 (Duke Univ. Dep't of Econ., Working Paper No. 2008-10, 2008) available at $\mathrm{http}$ ://econ.duke.edu/Papers/PDF/Data_Exclusivity_Periods_for_Biologics.pdf (reiterating Grabowski's call for a twelve- to sixteen-year exclusivity period) [hereinafter Grabowski et al.]; see also infra note 71. But see Fed. Trade Comm'n, Emerging Health Care Issues: FOLlow-ON BIOLOGIC DRUG COMPETTTION v-vii (2009), available at http://www.ftc.gov/os/ 2009/06/P083901 biologicsreport.pdf [hereinafter FTC REPORT] (recommending against granting statutory exclusivity in biological products in addition to existing patent protection and determining that it is likely that generic competition in biologics will develop without any special legislative incentives).

Notably, in Europe original biological products are afforded a ten- to eleven-year statutory exclusivity period consisting of eight years of data exclusivity during which it is not possible to file applications for generic versions of the biological product; two more years of market exclusivity, during which generic applications cannot be approved; and an additional optional one year for approval of additional treatment indications for the same product. See Commission Regulation 726/2004, 2004 O.J. (L 136) 11, 14 (EC). For further discussion of the European regulatory framework for the approval of generic biologics, see generally Kelly \& David, supra note 3, at 122-23; Liang, supra note 2, at 397-408.

6. For purposes of the discussion in this Article, a "statutory exclusivity" period is defined as the period of time designated in legislation during which the FDA or any other statutorily designated entity is barred from approving a generic version of a product or taking other action mandated in legislation which would pave the road for competition in that product. The effect of such statutory impediment is a de facto grant of a competitive advantage to the party owning or making the original version of the product. $C f$. Bruce S. Manheim et al., 'Follow-On Biologics': Ensuring Continued Innovation in the Biotechnology Industry, 25 HEALTH AFF. 394, 394 (2006), available at http://content.healthaffairs.org/cgi/content/full/ 25/2/394 (defining "statutory exclusivity" as "the period of time in which the FDA is barred from approving a follow-on product"). For further discussion of statutory exclusivities and the difference between statutory exclusivities and intellectual property rights, such as patents, see infra Part 1.B-C. Two examples of statutory exclusivities existing in the context of FDA regulation are those afforded under the Drug Price Competition and Patent Term Restoration Act of 1984 and the Orphan Drug Act. See Drug Price Competition and Patent Term Restoration Act of 1984 (Hatch-Waxman Act), Pub. L. No. 98-417, 98 Stat. 1585 (1984) (codified as amended in different sections of 15, 21, 35 and 42 U.S.C.); Orphan Drug Act, Pub. L. No. 97 414 , 6 Stat. 2049 (1983). For further discussion of these Acts and the statutory exclusivities they confer see infra Part I.B.

7. The Biologics Price Competition and Innovation Act (BPClA) was enacted as part of the Patient Protection and Affordable Care Act, Pub. L. No. 111-148, $\$ \$ 7001-7002,124$ Stat. $119(2010)$ (adding $\$ 351(k)(7)$ to the PHSA ch. 373, 58 Stat. 682 (1944)). See discussion infra Part II.C. Importantly, in February 2011 as part of its 2012 Budget Proposal, the Office of Management and Budget in the Executive Office of the President published a 
predominantly overlaps with patent protection on the underlying biological product and is about 5 to 11 months shorter than the average remaining period of such patent protection on the original product. ${ }^{8}$

This redundancy raises questions regarding the need for and purpose of having patents in inventions related to biologics in addition to statutory exclusivities. What justification is there, if any, for such double-layered protection in biologics? Assuming that such justification or need for double protection does exist, why should biologics be the only kind of technology to benefit from it? Could the statutory exclusivity regime in biologics mark the dawn of a new era in the protection and incentivizing of innovation and the beginning of a gradual replacement of the old patent system with modern schemes of statutory exclusivities; or is it just a peculiar case of a legal regime shaped by an unusually powerful industry? In this Article I will seek to address these questions and propose some answers.

Part I of this Article will review fundamental patent theory concepts necessary for the discussion and compare them with statutory exclusivities, with emphasis on the statutory exclusivity scheme created under the HatchWaxman Act. Part II will describe the current regulation of biologics in the United States and review the framework for the approval of generic biologics under BPCIA. Comparing statutory exclusivities and patent protection in the context of biologics, Part III will discuss the merits of these two regimes from a public policy perspective, address the possible ramifications of having both statutory exclusivities and patent protection in biologics, and culminate in a call for the suspension of patent enforcement rights with relation to biological products that benefit from statutory exclusivities afforded under BPCIA for the duration of such exclusivities.

proposal to shorten this exclusivity period to seven years. See OfFICE OF MGMT. \& BUdGET, Fiscal Year 2012 Terminations, Reductions, And Savings 119 (2012), available at http://www.whitehouse.gov/sites/default/files/omb/budget/fy2012/assets/trs.pdf [hereinafter BUDGET] ("The Administration is proposing to give consumers more access to affordable pharmaceuticals by ... reducing the exclusivity period for brand biologics to encourage faster development of generic biologics ... . Under the Administration proposal, beginning in 2012, innovator brand biologic manufacturers would have 7 years of exclusivity."). Interestingly, this proposal appears to be in line with the Administration's original position on the appropriate length of statutory exclusivity that should be awarded in approved original biological products. See infra note 87 and accompanying text. Regardless, the discussion herein is based on the law as it currently stands under BPCIA.

8. See discussion infra Part III.A. 


\title{
I. Statutory Exclusivities and Patents as Mechanisms of Protecting and Advancing TECHNOLOGICAL INNOVATION
}

\begin{abstract}
A. Patents
Dating as far back as the fifteenth century, ${ }^{9}$ patents ${ }^{10}$ are time-limited monopolies granting the right to exclude others from using patented inventions; ${ }^{\prime \prime}$ i.e., for a predefined period of time, patentees can dictate whether and how third parties may practice the patented inventions and collect payments in exchange for the patentee's permission to do so. The literature on patent theory is vast, but two theories dominate the underlying rationales for having patent systems. ${ }^{12}$
\end{abstract}

\section{Patents as Incentive to Disclose}

According to this theory, patents embody a pact between inventors and society: in exchange for revealing to society their inventions and the way to utilize them, society grants inventors monopoly rights in their inventions for a limited period of time. ${ }^{13}$ This patent theory presumes that inventors would

9. See Giulio Mandich, Venetian Patents (1450-1550), 30 J. PAT. OfF. SOC'y 166, 169 (1948).

10. In the context of this Article, unless stated otherwise, reference to "patents" is to the modern form of patents of invention-i.e., utility patents - as opposed to design patents, plant patents, and other types of patents.

11. In the United States, the right to exclude includes the making, using, offering for sale or selling of the invention, or importation of the invention into the United States. See 35 U.S.C. \$271(a); see also Staff of S. Subcomm. on Patents, Trademarks, \& Copyrights of the Comm. on the Judiciary, 85th Cong., An Economic Review of the Patent SysTEM 1 (Comm. Print 1958) [hereinafter ECONOMiC Review of Patent System] ("a patent confers the right to secure the enforcement power of the state in excluding unauthorized persons, for a specified number of years, from making commercial use of a clearly identified invention").

12. Although it is generally accepted that inventive activity is responsive to economic stimuli, the need for patents as effective and efficient means of providing such stimuli remains the subject of debate. See Rebecca S. Eisenberg, Patents and the Progress of Science: Exclusive Rights and Experimental Use, 56 U. CHI. L. Rev. 1017, 1031 (1989) ("There is considerable empirical evidence suggesting that technological change has been an extremely important source of economic growth over time, and that levels of invention are responsive to economic stimuli. But it does not necessarily follow that patent protection is necessary to preserve adequate economic incentives for invention and innovation."). Notably, the patent theory literature recognizes additional rationales for patents. One proposition is that patents are a natural right, because inventors have natural property rights in their ideas, and thus to prevent theft of such ideas by unauthorized parties, society is morally obligated to afford inventors a proprietary right in their inventions that would confer exclusivity in the invention. See EConomic Review of PATENT System, supra note 11, at 21. Another somewhat archaic rationale for patents is that patents are a means of securing appropriate rewards, namely, that principles of justice and "natural law" require that inventors receive rewards for their inventions proportional to the inventions' usefulness to society. See id.

13. See ECONOMic Review of Patent System, supra note 11, at 21 (describing the "exchange-for-secrets" thesis); Eisenberg, supra note 12, at 1022, 1028-30 ("In exchange for 
have kept their inventions secret for as long as possible, but the exclusivity is sufficient to convince them to disclose and explain their inventions and thus benefit society. ${ }^{14}$ An underlying premise of this theory is that the required disclosure of the invention by the inventor, once made, will enable the public to build upon the disclosed technology to further innovation. ${ }^{15}$ These assumptions have been the subject of critique, especially in view of arguments that many patents withhold vital information necessary for utilizing the inventions without additional, sometimes substantial, research and development ("R\&D”). ${ }^{16}$

\section{Patents as Incentive to Invent/Invest}

A modern, broadly accepted perception of patents is as an instrument of incentivizing invention by affording inventors an extra-competitive advantage over their competitors. ${ }^{17}$ Described as "the fundamental economic justification of patents," 18 the basic premise upon which this theory is based is that under competitive conditions the protit made by inventors would not be high enough to justify their investment and that in order to make inventive activities worthwhile to inventors, society must ensure that the inventors are able exploit their inventions to an extent that sufficiently compensates them for their investment of time, money, and effort. ${ }^{19}$

Further evolvement of the incentive-to-invent theory views patents as vital not only for the inventive activity itself but also for the industrial appli-

these exclusive rights, the patent statute requires the inventor to disclose the invention in the patent application in terms sufficient to enable others who are 'skilled in the art' to make and use it.").

14. See Economic Review of PATENT System, supra note 11, at 21; Eisenberg, supra note 12 , at $1028-30$.

15. See Economic Review of PATENT System, supra note 11 , at 21 .

16. See id. at 32-33; Sean B. Seymore, The Teaching Function of Patents, 85 Notre DAME L. REv. 621, 626 (2010).

17. See Economic Review of Patent System, supra note 11, at 21 (the "monopolyprofit-incentive" thesis); Eisenberg, supra note 12, at 1024-26 ("The incentive to invent theory holds that too few inventions will be made in the absence of patent protection because inventions once made are easily appropriated by competitors of the original inventor who have not shared in the costs of invention."). Notably, this perception of patents also seems to lie in the heart of the Constitutional authorization of Congress to grant patents for the purpose of promoting scientific progress. See U.S. Const. art. I $\$ 8$ ("ICongress shall have Power ... To promote the Progress of Science and useful Arts, by securing for limited Times to ... Inventors the exclusive Right to their ... Discoveries"). An important critique of the perception of patents as incentive-to-invent argues that people would create and invent regardless of any prospect of gain. See Economic Review of Patent System, supra note 11, at 34 (quoting Frank W. Taussig).

18. ECONOMIC Review of Patent Srstem, supra note 11 , at 32.

19. Id. at $32,37,39$ (reviewing arguments made by several scholars, including A.T. Hadley and Joseph Schumpeter); see also BRILL, supra note 5, at 6 ("The purpose of the patent system is to ensure that the inventor of a patented product receives monopoly market conditions and can earn profit margins sufficient to induce the R\&D costs associated with bringing the product to market."). 
cation of resulting inventions, ${ }^{20}$ namely for the incentivizing of financing of the steps necessary to put an invention into the market. ${ }^{21}$

Despite extensive criticism of the incentive-to-disclose and incentive-toinvent/invest theories, ${ }^{22}$ they offer means for evaluating the utility of patents. Thus, in examining patents in the context of biologics, I will assume that these patent theories are valid and capable of explaining, at least to some extent, the need for patent protection for inventions in general and biotechnological inventions in particular.

\section{B. Statutory Exclusivities}

The classic view on monopolies, whether patent or otherwise, is that they are generally harmful to society, but "a temporary monopoly granted to an inventor [is] a good way of rewarding his risk and expense." 23 This maxim is equally applicable to both patents and other types of state-instituted monopolies, such as statutory exclusivities. ${ }^{24}$

20. For purposes of the discussion herein, this hypothesis will be referred to as the "incentive-to-invest" theory. Notably, the invention/investment terminology used herein bears similarity to the distinction drawn by some scholars between "invention" and "innovation." For example, Eisenberg refers to the incentive-to-invest offshoot of the incentive-to-invent rationale as a separate patent theory according to which patents are meant to promote "innovation," namely investment in practical and commercial development of existing inventions. See Eisenberg, supra note 12, at 1024 n.29, 1037-45; see also Robert P. Merges, Commercial Success and Patent Standards; Economic Perspectives on Innovation, 76 CAL. L. Rev. 803, 807 (1988) ("An invention refers to the practical implementation of the inventor's idea. This often takes the form of a prototype or model. An invention, then, is more than a concept (it is usually a tangible thing), but less than the fully worked out product or process first offered for sale to customers. An innovation is the 'debugged' and functional version of the invention: the version first offered for sale.").

21. See Eisenberg, supra note 12, at 1024 n.29, 1037-45; ECONOMIC REviEw of PATENT SYSTEM, supra note 11 , at 36 ("Financing the work that leads to the making of an invention may be a relatively small venture compared with that of financing its introduction, because costly development work, experimentation in production, and experimentation in marketing may be needed before the commercial exploitation of the invention can begin."). The incentive-to-invest theory is especially relevant to the medical products industry, in which the expense associated with identifying a promising drug or biologic is often not remotely as costly as putting it through clinical trials as required by the FDA.

22. See, e.g., 2008 CRS REPORT, supra note 1, at 18; Eisenberg, supra note 12, at 1026-30 (addressing the critiques on the incentive-to-disclose and incentive-to-invent theories); ECONOMIC Review of PATENT System, supra note 11, at 22-25 (describing critiques of arguments in favor of patent protection).

23. See Economic Review of Patent System, supra note 11, at 19. But see BriLl, supra note 5, at 11 (warning about the chilling effects of too-long monopoly periods and arguing that "excessive monopoly protection by the government creates windfalls to innovators, stifles competition and is costly to society").

24. For example, the sui generis rights under the Plant Variety Protection Act (PVPA), Pub. L. No. 91-577, 84 Stat. 1542 (1970) (codified at various sections in 7 U.S.C.); the Semiconductor Chip Protection Act of 1984, Pub. L. No. 98-620, 98 Stat. 3347 (codified at 17 U.S.C. $\$ \$ 901-914$ (2006)); and the Vessel Hull Design Protection Act, Pub. L. No. 105-304, 112 Stat. 2860, 2905 (1998) (codified at 17 U.S.C. $\$ \$ 1301-1332$ (2006)). Notably, the arguments in favor of granting statutory exclusivities in biologics-encouraging innovation and 
As mentioned above, a statutory exclusivity is a time-limited monopoly in a product or products that is the result of a bar on the entry of competitors into the product's market. ${ }^{25}$ The most significant example of statutory exclusivities is that of the exclusivity periods granted under the Hatch-Waxman Act. ${ }^{26}$ The Hatch-Waxman Act creates the regulatory pathway for the approval of generic versions of small-molecule drugs and provides for several types of statutory exclusivities. First, the Hatch-Waxman Act offers a fiveyear statutory exclusivity period available to original drug manufacturers for receiving marketing approval of drugs containing therapeutic chemical compounds that have not been previously approved for medical use. ${ }^{27}$ As I will explain later in this Article, although the five-year new chemical entity ("NCE") exclusivity and 12- to 12.5-year statutory exclusivity under BPCIA may seem like they are meant to function in the same way (as though the 12- to 12.5-year market exclusivity is "NCE exclusivity for biologics"), their purpose is in fact quite different. ${ }^{28}$ Additionally, the Hatch-Waxman Act creates a three-year statutory exclusivity period for conducting supplemental clinical investigations that lead to the approval of a new medical use of an already approved drug. ${ }^{29}$ Finally, the Hatch-Waxman Act seeks to incentivize the creation of generic versions of drugs by granting a 180-day exclusivity period to companies that are first to file applications for the mar-

enabling innovators to gain sufficient profit-bear striking resemblance to the incentive-toinvent/invest patent rationale discussed above. See infra notes 72-73 and accompanying text. For further discussion of the resemblance between the rationales for granting patents and statutory exclusivities, see infra Part III.C.

25. See supra note 6 . In terms of their effect, statutory exclusivities are highly similar to patents. According to the Economic Review of the Patent System, patents have three characterizing features: conditionality, limitation of time and scope, and their being awarded by society for a recognizable reason. ECONomic Review of PATENT System, supra note 11, at 26 ("most writers [writing about patents] want to make it understood that [patents] are not 'odious' monopolies but rather 'social monopolies,' 'general welfare monopolies,' or 'socially earned' monopolies ... . [All patent monopolies] are 'limited and conditional.'”).

26. See Hatch-Waxman Act, supra note 6. For an overview of the Hatch-Waxman Act and its legislative history see generally Gerald J. Mossinghoff, Overview of the Hatch-Waxman Act and lts Impact on the Drug Development Process, 54 Food \& Drug L.J. 187 (1999); see also Gitter, supra note 2, at 568-73.

27. See 21 U.S.C. $\$ 355$ (c)(3)(E)(ii) (2006). This exclusivity period is commonly known as "new chemical entity" (NCE) exclusivity. During the NCE period of exclusivity, a generic version of the same drug cannot be approved. $I d$. However, a generic applicant may file an application for the approval of a generic version of the drug after four years by challenging the patents related to the original product under 21 U.S.C. $\$ 355(j)(5)$ (B)(iv)(II). Such a challenge would normally prompt the filing of a lawsuit by the patent owner, which would trigger - regardless of the timing in which the challenge was made with relation to the NCE exclusivity -an additional period of thirty months (or 7.5 years from the date of approval, if the filing was made between NCE years four and five) during which the FDA may not approve the generic application. See 21 U.S.C.A. $\$ 355(j)(5)$ (B)(iii) (West 2012). For further discussion of the NCE exclusivity period and its underlying rationale, see infra Part II.C.

28. See infra notes $90-92$ and accompanying text.

29. See 2 I U.S.C. $\$ \$ 355$ (c)(3)(E)(iii)-(iv) (2006). This additional exclusivity period is meant to incentivize further investment in $R \& D$ of a known drug. 
keting of generic versions of an original drug product. ${ }^{30}$ However, in order to receive the 180-day exclusivity, a generic applicant must challenge patents related to the original drug. ${ }^{31}$ The flourishing generic drug market and the entire generic drug industry are commonly viewed as attributable to this statutory exclusivity scheme created under the Hatch-Waxman Act. ${ }^{32}$

Another important example of a statutory exclusivity framework is that of the exclusivities granted under the Orphan Drug $\mathrm{Act}^{33}$ to developers of drugs for rare diseases ${ }^{34}$ such as Huntington's disease, amyotrophic lateral sclerosis (ALS) (Lou Gehrig's disease), and Tourette syndrome. ${ }^{35}$ Under the Orphan Drug Act, once an approved drug or biologic is approved and "designated under [21 U.S.C. $\$ 360 \mathrm{bb}$ ] for a rare disease or condition, the [FDA] may not approve another application ... for such drug for such disease or condition for a [generic applicant] until the expiration seven years from the date of the approval of the [drug or biologic]." 36 The idea behind the legislation of the Orphan Drug Act was to increase insufficient financial incentives under patent law, thereby making the development of drugs for rare diseases financially feasible. ${ }^{37}$ The seven-year market exclusivity that is the crux of the Orphan Drug Act is considered to have achieved its desired effect: since its passage in 1983, more than 200 drugs and biologics for rare diseases and

30. See 21 U.S.C. $\$ 355(\mathrm{j})(5)(\mathrm{B})(\mathrm{iv})$ (2006). The benefit embodied in the 180-day exclusivity period for generic manufacturers lies in the recipient's ability to charge nearmonopoly prices for its generic version of the drug for the duration of the 180-day exclusivity period. See Gitter, supra note 2, at 573 (noting that during the 180-day period the generic drug "shares duopoly prices with the Brand-name drug").

31. See 21 U.S.C. $\$ 355(\mathrm{j})(5)$ (B)(iv)(II) (2006). Thus, the Hatch-Waxman Act itself incentivizes the challenging of patents related to the original drug product. In this respect, the Hatch-Waxman Act seeks to abolish one monopoly by offering another, shorter one.

32. The Hatch-Waxman Act is considered a great success in terms of incentivizing R\&D activities in monetary terms due to the savings attributable to the approval of generic versions of innovative drugs. See Gitter, supra note 2, at 586-87 (reviewing the reasons for what the author describes as the "overall success" of the Hatch-Waxman Act); Liang, supra note 2, at 365 (arguing that the Hatch-Waxman Act has been very successful in bringing cheaper generic versions of drugs to the market while maintaining incentives for continued innovation).

33. Orphan Drug Act, Pub. L. No. 97-414, 96 Stat. 2049 (1983) (codified at 21 U.S.C. $\$ \$ 360 \mathrm{aa}-360 \mathrm{ee}$ and 42 U.S.C. $\$ 236(2006))$.

34. See 21 U.S.C. $\$ 360 \mathrm{bb}(\mathrm{a})(2)$ (2006) (defining "rare disease or condition"). The definition of an orphan drug could also include "orphan" biologics approved under PHSA $\$ 351$.

35. See Congressional Findings for the Orphan Drug Act II (2011), available at http://www.fda.gov/regulatoryinformation/legislation/federalfooddrugandcosmeticactfdcact/ significantamendmentstothefdcact/orphandrugact/default.htm.

36. 21 U.S.C. $\$ 360 \mathrm{cc}(\mathrm{a})(2)(2006)$.

37. See Congressional Findings for the Orphan Drug Act, supra note 35 , III 2 , 4-5. Such orphan drug products may be entirely unpatentable and could still merit exclusivity under the Orphan Drug Act. Id. 
conditions have been brought into the market as compared with fewer than ten in the decade preceding the passage of the Act. ${ }^{38}$

\section{Patents and Statutory Exclusivities- Similarities and Differences}

The main difference between statutory exclusivities and patents involves the nature or type of "right." 39 Patents result from a grant by an executive agency-the United States Patent and Trademark Office ("USPTO")-and create a right to exclude others from making, using, selling, offering to sell, or importing into the United States the object of the right, namely the invention as claimed. ${ }^{40} \mathrm{~A}$ patentee's right to exclude is correlated with the duty of third parties not to use the invention without the patentee's permission. ${ }^{41}$

Statutory exclusivities, on the other hand, are the result of inaction by an executive agency that effectuates a de facto monopoly status with respect to a particular product. For example, the NCE exclusivity under the HatchWaxman Act is a result of prohibiting the FDA from granting marketing approvals for generic versions of the original drug for a period of tive years from the date of approval of that drug, thereby effectuating a five-year exclusivity in that drug on its developer. ${ }^{42}$ In other words, the benefits of statutory exclusivities to developers of original products are by-products of the preclusion of potential competitors by an executive agency withholding its permission to partake in a regulated activity. ${ }^{43}$

38. See Frank R. Lichtenberg \& Joel Waldfogel, Does Misery Love Company? Evidence from Pharmaceutical Markets Before and After the Orphan Drug Act, $15 \mathrm{MiCH}$. Telecomm. Tech. L. Rev. 335, 348 (2009) (arguing that the Orphan Drug Act "works"); Food \& Drug Admin., Developing Products for Rare Diseases \& Conditions, available at http:/www.fda.gov/forindustry/developingproductsforrarediseasesconditions/default.htm (last updated Mar. 20, 2012).

39. This part of the discussion will utilize the terminology and distinctions proposed by Hohfeld. See generally Wesley Newcomb Hohfeld, Some Fundamental Legal Conceptions as Applied in Judicial Reasoning, 23 YALE L.J. 16 (1913) (providing background terminology).

40. Notably, patents are commonly mistaken for a positive right to use an invention. The distinction between a right to use and a mere right to exclude others may be best illustrated where a patentee is unable to use her own invention but still has the right to exclude others from using it. For example, if A's invention cannot be used without B's patented technology, then A would be unable to use B's technology although A would certainly still be able to prevent $C$ from using $A$ 's technology even if $C$ has a license from $B$ to use $B$ 's technology.

41. See Hohfeld, supra note 39, at 32 ("A duty or a legal obligation is that which one ought or ought not to do. 'Duty' and 'right' are correlative terms. When a right is invaded, a duty is violated." (quoting Lake Shore \& M. S. Ry. Co. v. Kurtz, 37 N.E. 303, 304 (Ind. App. 1894))).

42. See discussion of NCE exclusivities, supra note 27 and accompanying text.

43. For example, the FDA does not owe an original drug manufacturer a five-year monopoly status for having a new chemical entity approved for medical use. Rather, the FDA is merely obliged to refrain, for a period of five years, from approving generic versions of the particular chemical compound for the drug's indicated medical use. Put in Hohfeldian terms, statutory exclusivities are the result of a privilege granted to applicant $A$ to partake in certain commercial activities requiring a license from an executive agency $E$. Yet the exclusivity itself 
The difference in the nature of the right conferred by patents and statutory exclusivities dictates two additional important distinctions related to the enforceability of the respective rights and their susceptibility to legal challenges. From an enforceability perspective, while patents give grantees the right to preclude others from taking certain actions as they relate to the inventions claimed by such patents, ${ }^{44}$ statutory exclusivities are merely immunities and confer no right per se (in the narrow Hohfeldian sense) on their bearer. ${ }^{45}$ Accordingly, enforcement of patent rights necessitates actively seeking relief from a court and, typically, requires significant investment of resources. Statutory exclusivities, on the other hand, are "automatically enforced" by the regulatory bar that precludes the entry of potential competitors into the relevant market and, thus, require no enforcement action per se on the part of the parties benefiting from them. ${ }^{46}$

Patents and statutory exclusivities also differ in their susceptibility to legal challenges. Patents, while presumed valid, ${ }^{47}$ are subject to several different types of challenges, including those during post-grant proceedings (such as reexamination), ${ }^{48}$ defense arguments in patent infringement suits, ${ }^{49}$

is not the result of the privilege but rather of an immunity of A from having its monopoly status changed which correlates to a non-ability of third parties $\mathrm{C}$ to abolish this monopoly status of A by securing approval of their own generic products from agency E. See Hohfeld, supra note 39 , at 55 (discussing the concepts of immunity and disability).

44. See supra notes 11 and 40 and accompanying text.

45. It is possible to argue that from a legal standpoint the beneficiaries of statutory exclusivities could secure certain legal rights, e.g., if agency E, for some reason, goes ahead and approves an application of third party $\mathbf{C}$ prior to the expiration of the relevant statutory exclusivity period, applicant $A$ may be entitled to recover damages from agency $E$ at the amount that $A$ could have reasonably expected to gain from its monopoly status had agency $E$ not approved C's application. In this regard, it is important to distinguish between the type of right per Hohfeld and the legal right. See, e.g., Hohfeld, supra note 39, at 43-44 (explaining that there are "innumerable cases in which the mental and physical facts ... [are] confused with the legal relation which they create").

46. See BRILl, supra note 5, at 6 ("[d]ata exclusivity is a definitive monopoly and a government grant, as it allows the innovator's data to be protected without challenge"); Joyce Wing Yan Tam, Biologics Revolution: The Intersection of Biotechnology, Patent Law, and Pharmaceutical Regulation, 98 GEO. L.J. 535, 553 (2010) ("Marketing exclusivities are particularly powerful. . . [ $t$ ]his perfect monopoly protection is automatic and does not require the entity holding the market exclusivity to act-a sharp contrast to patent rights, which are only enforced when the patent holder prevails in a legal action."). However, a party benefiting from a statutory exclusivity could attempt to preserve and possibly even extend its monopoly by filing a citizen petition requesting the FDA to take certain actions (e.g., imposing increased testing requirements on generic applicants) or refrain from taking certain actions (e.g., approving a generic application). See 21 C.F.R. $\$ 10.30(2001)$.

47. See 35 U.S.C. $\$ 282$ (2006) (“[a] patent shall be presumed valid”).

48. See 35 U.S.C. $\$ \$ 302-05$ (2006).

49. Patent infringement suits initiated under the Hatch-Waxman Act normally fall under this category. Namely, the third party generic applicant makes a certification under 21 U.S.C. $\$ 355(\mathrm{j})(2)$ (A)(vii)(IV) that the patents covering the original drug product are "invalid or will not be infringed by the manufacture, use, or sale of the new drug for which the application is submitted." Such certifications constitute acts of infringement under 35 U.S.C. $\$ 271(\mathrm{e})(2)$. See discussion supra notes 30-31 and accompanying text. 
and suits for a declaratory judgment ${ }^{50}$ Such challenges could and often do result in the partial or complete invalidation of the challenged patents. ${ }^{51}$ Hence, it is possible to say that patents are substantially exposed to legal challenges throughout their term.

Statutory exclusivity status, however, can only be contested by challenging the relevant agency's inaction (i.e., omission), e.g., by disputing the agency's "failure" to approve an application to partake in the particular regulated activity that is the subject of the exclusivity. Since such a challenge would essentially argue that the agency should have approved the additional, later application, its prospects of success in court are not high from the outset. ${ }^{52}$ Thus, statutory exclusivities are substantially less susceptible to legal challenges than patents.

Having laid down some of the foundations necessary for a discussion of patents and statutory exclusivities in the context of biologics, I will now provide background on the regulation of biological products.

50. Suits for declaratory judgment may be brought under 28 U.S.C. $\$ 2201$. But see Federal Food, Drug, and Cosmetic Act (abbreviated as FFDCA, FDCA, or FD\&C), ch. 675, 52 Stat. $1040, \$ \$ 505,512$ (1938) (providing exceptions to one's ability to sue for declaratory judgment).

51. For example, patents are susceptible to challenges involving their novelty and nonobviousness under 35 U.S.C. $\$ \$ 102-103$, their compliance with the various requirements of 35 U.S.C. $\$ 112$, their being directed to patentable subject matter under 35 U.S.C. $\$ 101$, and so forth.

52. Under current Supreme Court precedent, challenging executive agencies' inaction is likely to be unsuccessful. See Heckler v. Chaney, 470 U.S. 821, 831 (1985) ("This Court has recognized on several occasions over many years that an agency's decision not to prosecute or enforce, whether through civil or criminal process, is a decision generally committed to an agency's absolute discretion."). The low likelihood of success of an attempt to challenge executive agencies' inaction is especially true in the context of drug law. See id. at 835-36 (rejecting the argument that the FFDCA's prohibitions of "misbranding" and the introduction of "new drugs" absent agency approval supply courts with "law to apply" and, accordingly, that they do not provide a basis for judicial review of an FDA decision not to take enforcement action in the area of drug law); see also BRILL, supra note 5, at 6 ("Data exclusivity is not challengeable in court.").

Although statutory exclusivities per se may be relatively unsusceptible to legal challenges, it is quite possible that an agency's interpretation and application of laws instituting such exclusivities would be subject to legal challenges. However, such challenges would be subject to the exacting review standard of the Chevron Doctrine. See Chevron U.S.A. Inc. v. Natural Res. Def. Council, Inc., 467 U.S. 837, 842-44 (1984) (holding that "considerable weight should be accorded to an executive department's construction of a statutory scheme. ." and that so long as (1) "Congress has [not] directly spoken to the precise question at issue" and (2) "the agency's answer is based on a permissible construction of the statute," then "the principle of deference to administrative interpretations [should be] followed"). 


\section{The Regulation of Biologics in the United States}

\section{A. The Approval of Biologics License Applications Under PHSA § 351}

In order to introduce a biological product into interstate commerce, the product's developer must first receive a biologics license from the FDA. ${ }^{53}$ Under FDA regulations, the FDA may grant a biologics license pursuant to the submission of a biologics license application ("BLA") showing that the biological product is sufficiently safe, effective, and pure. ${ }^{54}$ Demonstrating compliance with the FDA's safety, efficacy, and purity standards normally requires having the biological product undergo extensive and lengthy $R \& D$ and regulatory approval processes. ${ }^{55}$ Naturally, these R\&D and approval efforts impose significant financial burdens on BLA applicants. The price of putting a new biological product on the market is commonly estimated at around $\$ 1.24$ to 1.32 billion on average for a typical product. ${ }^{56}$ As a result, biologics are usually very expensive. ${ }^{57}$

53. Under PHSA $\$ 351(\mathrm{a})(1)(\mathrm{A})$, “[n]o person shall introduce or deliver for introduction into interstate commerce any biological product unless ... a biologics license is in effect for the biological product." Notably, the FDA has approved several biologics through regulatory pathways created by FFDCA, e.g., human insulin products such as Humulin and Humalog, human growth hormone products such as Humatrope, Norditropin, and Saizen, and more. See Vernon et al., supra note 5, at 59-60 (discussing approval of some biologics under the framework of FFDCA). These biologics have mostly been well-known, less structurally-complex compounds and in some cases are versions of already-approved biologics that have gone offpatent. However, such cases are an exception to the general rule that biologics are subject to the approval processes set forth primarily in PHSA, and it is likely that the formation of a regulatory pathway for the approval of generic biologics under BPCIA (see infra Part II.C) would marginalize them even further. Thus, in analyzing implications of BPCIA, I will assume that future regulation of biologics is going to be done primarily, if not exclusively, under PHSA.

54. See PHSA \$ 351(a)(2)(B)(i)(I); 21 C.F.R. $\$ 600.2(2011)$.

55. See, e.g., 21 C.F.R. $\$ \$ 601.2(\mathrm{a}), 601.20,601.25,601.27,601.70$ (2012). For further discussion of the typical length of the development of biological products, see infra Part III.A.

56. See Joseph A. DiMasi \& Henry G. Grabowski, The Cost of Biopharmaceutical $R \& D:$ Is Biotech Different?, 28 MANAGERIal \& Decision Econ. 469, 475 (2007) (estimating the cost of putting a typical biologic on the market, including success in obtaining regulatory marketing approval, at around \$1.24-1.33 billion (2005 U.S. dollars)) [hereinafter DiMasi \& Grabowski]; Gitter, supra note 2, at 567, 589 (reviewing the significant investment required from biologics' manufacturers as compared to small-molecule drugs); KoTLIKofF, supra note 5 , at 8 ("bringing a new biologic medication to market is exceptionally expensive-an estimated \$1.24 billion"); Vernon et al., supra note 5, at 66-68 (discussing the high costs involved in the development and manufacturing of biologics). These high development costs are at least partially attributable to the fact that only about one in three biological products that start clinical trials eventually receive FDA approval. See BIO WhITE PAPER, supra note 2, at 4 ("II]t is estimated that less than a third of the biopharmaceuticals that enter clinical trials ever receive marketing approval.").

57. The annual price of some biologics tends to be very high; some could cost over $\$ 100,000$ or, in rare instances, even over $\$ 300,000$ a year. See FTC REPORT, supra note 5, at i ("[A]nnual treatment for breast cancer with ... Herceptin can cost $\$ 48,000$ and the annual treatment for rheumatoid arthritis with Remicade can cost approximately $\$ 20,000$.”); Kathleen 
While the high prices of biologics may be justified, they also give rise to concerns of possible abuses of market position by manufacturers of original biologics. Some commentators have argued that manufacturers of original biological products use the high entry barriers into the biologics market ${ }^{58}$ the result of the significant time, money, and expertise necessary in order to put biologics on the market-to charge very high prices for their products well after they have recouped their development costs. ${ }^{59}$ One of the proposed solutions for this perceived market failure is the creation of a regulatory pathway for the approval of generic versions of biologics. ${ }^{60}$

\section{B. Regulatory Pathways for the Approval of Generic Pharmaceuticals-Background}

As demonstrated by the generic scheme created under the Hatch-Waxman Act, regulatory frameworks for the approval of generic pharmaceuticals are established on the premise that identical or highly similar compounds are assumed to be equally or similarly safe and effective ${ }^{61}$ and therefore require

R. Kelleher, FDA Approval of Generic Biologics: Finding a Regulatory Pathway, $14 \mathrm{MiCH}$. TEleCOMM. TECH. L. Rev. 245, 252 (2007) (discussing the reasons for the relatively high prices of biologics); SHaPIRO, supra note 4, at 4 (listing the high costs of several prominent biologics); Editorial, When a Drug Costs $\$ 300,000$, N.Y. Times, Mar. 23, 2008, http:/www.nytimes.com/2008/03/23/opinion/23sun3.html (discussing the high annual cost of some biologics used for treating rare diseases); Kendra Marr, Biotech Campaigns for Easier Access to Generic Drug Market, WASH. POST, Aug. 13, 2008, at DI ("[ $\mathrm{t}$ ]reatment [with biologics] can cost a patient more than $\$ 30,000$ a year, prohibiting many from obtaining drugs").

58. See Gitter, supra note 2, at 589-90 (recognizing the high entry barriers faced by generic manufacturers seeking to enter the biologics market); Sarah Sorscher, Note, A Longer Monopoly for Biologics?: Considering the Implications of Data Exclusivity as a Tool for Innovation Policy, 23 HaRv, J.L. \& TECH. 285, 304 (2009) (discussing the high entry barriers into the generic biologics market, especially as compared to the entry barriers faced by manufacturers of generic small-molecule drugs).

59. See Dinh, supra note 3, at 79 ("Besides the expenses of R\&D and clinical trials, the high cost of biologics results from monopoly pricing of brand-name biologics . . . after patent expiration because the regulatory approval process delays the market entry of competing products."); Kelleher, supra note 57, at 252-53 (arguing that biologics are unjustifiably expensive and that the lack of competition in biologics costs the U.S. economy billions of dollars annually).

60. The institution of a regulatory pathway for the approval of generic versions of already approved drugs was the solution chosen for a similar problem in the context of small-molecule drugs. See Hatch-Waxman Act, supra note 6. The legislation of the Hatch-Waxman Act (and the creation of the generic pharmaceutical industry that followed) was the result of the growing awareness during the 1970 s and early $1980 \mathrm{~s}$ of a similar situation that existed with relation to small-molecule drugs. For additional possible solutions to the market failure existing in the area of biologics, see Sorscher, supra note 58, at 301-02 (reviewing additional mechanisms for addressing the problem of diminished competition in the biologics market such as costsharing and prize funding that could potentially facilitate access to proprietary biological products' clinical data and manufacturing know-how).

61. See BIO White PAPER, supra note 2, at 10 ("Being identical to the innovator product allows FDA to rely on the innovator's safety and effectiveness data in determining that the generic version of the product will be safe and effective."); Dawn Willow, The Regulation of Biologic Medicine: Innovators' Rights and Access to Healthcare, 6 CHI.-KENT J. INTELL. 
relatively little, if any, additional clinical testing prior to approval. ${ }^{62}$ The sought-after result of such lowered testing requirements is that the development costs of later products will be lower and, as a result, so will their prices, thereby increasing their affordability and accessibility. In other words, regulatory frameworks for the approval of generic versions of pharmaceuticals seek to save the high development costs involved in putting a candidate compound through all the stages of drug development by simply ensuring its identity to or interchangeability with the original product. ${ }^{63}$ Such identity or interchangeability, in turn, is deduced based on comparison of the original product with the generic product. ${ }^{64}$

Prop. 32, 39 (2006) ("The principle underlying [a determination that two compounds have the same safety and efficacy profiles] is that the greater the degree of similarity or identity between two [compounds], the greater the confidence that their clinical performance will be similar or the same.").

62. See Woodcock Statement, supra note 1, at 6 ("By establishing that the drug product described in the [generic application] is the same as the approved innovator drug product, the []applicant can rely on the Agency's finding of safety and effectiveness for the approved drug. ... Therapeutic equivalents can be expected to have the same clinical effect and safety profile when administered to patients under the conditions specified in the labeling."); FTC REPORT, supra note 5, at ii ("Duplication of safety and efficacy information is costly, an inefficient use of scarce resources, and, as the FDA has explained, raises ethical concerns associated with unnecessary human testing.").

63. Notably, the ability to achieve such identity or comparability between the biological compounds in the original biologic and the ones in a later, generic version of the biologic, thereby allowing recognition of the generic version of the biologic as interchangeable with the original product, has been a point of significant scientific and legal disagreement. For further discussion of the issue of biosimilarity and bioequivalence of biological compounds, see Woodcock Statement, supra note 1, at 1, 4, 7-12 (stating that there is general recognition that the idea of "sameness" is not applicable to biologics in the same manner it is to small molecule drugs, addressing the FDA's definitions for the terms "comparability," "therapeutic equivalents," and "interchangeability," and reviewing the scientific challenges involved in comparing proteins and approving two biologics as substitutable/interchangeable); $2008 \mathrm{CRS}$ REPORT, supra note 1, at 7-9, 22-23 (describing the scientific and legal dispute regarding comparability of biological products); Dinh, supra note 3, at 90-94, 114-15; Gitter, supra note 2, at 590-609 (arguing that current scientific knowledge enables making determinations regarding comparability of two biologics sufficient to justify an abbreviated regulatory pathway for the approval of protein-based biological products and making the case for such regulation); Liang, supra note 2 , at 370-78, 415-17 (reviewing the difficulties in replicating biological compounds and the resulting safety concerns arising in the context of generic biologics); Marr, supra note 57 (describing the debate surrounding the ability to achieve and show similarity in biologics). The enactment of BPCIA seems to accept the premise that there is a way to achieve and ascertain identity or similarity between two biological compounds.

64. The comparison is of both the structures of the respective compounds and their physiological effects. See Willow, supra note 61, at 37 ("By establishing that the drug product described in the [generic application] is the bioequivalent of the innovator drug product approved [by the FDA], the [generic] applicant can rely on the FDA's finding of safety and effectiveness previously determined for its counterpart brand drug."). Notably, the generic applicant does not need and is not expected to acquire the actual clinical safety and efficacy data for the original product, which-while submitted to the FDA as part of the approval process of the original product-is considered proprietary, but rather "refers" the FDA to such data, which is already in the FDA's possession. See discussion infra note 159, $\mathbb{1} 2$. 
However, regulatory pathways for the approval of pharmaceutical products also invite free riding by generic manufacturers who do not participate in the substantial investment normally involved in the R\&D of pharmaceutical products. ${ }^{65}$ Thus, it is necessary to ensure that developers of original pharmaceuticals are able to recoup their investment and reap profits sufficient to incentivize continued R\&D efforts. Both the Hatch-Waxman Act and BPCIA rely on statutory exclusivities for this purpose. ${ }^{66}$ Despite differences in the length and scope of these exclusivities, all essentially guarantee that for a certain amount of time the government will not allow potential competitors to enter the relevant market or take steps toward doing so. ${ }^{67}$

\section{The Framework for the Approval of Generic Biologics Under the Biologics Price Competition and Innovation Act}

With the increase in the prevalence of biologics, ${ }^{68}$ there have been increasing calls and proposals for the institution of a framework for the

65. See 2008 CRS REPORT, supra note 1, at 20-21 (demonstrating the differences in cost and risk between development of an original new pharmaceutical and a generic version thereof).

66. See supra Part I.B and infra Part II.C. I will argue later in this Article that the statutory exclusivities afforded to developers of original pharmaceuticals under the Hatch-Waxman Act are different from the ones instituted under BPCIA not only in their length -3 to 6 years as compared to 12 to 12.5 years respectively--but also in their purpose and in the extent of protection they afford to the interests of developers of original pharmaceutical products. See infra Part II.C.

67. It is common to refer to two main types of exclusivities in the context of regulatory frameworks for approval of generic pharmaceuticals products: (1) "market exclusivity" (also sometimes referred to as "approval exclusivity" or as "generic exclusivity" when discussing statutory exclusivities in general, namely not in the particular context of generic competition): a period during which potential generic competitors are not allowed to enter the particular product's market, which is typically enforced by a prohibition on the FDA to approve applications for comparable generic products for the duration of the exclusivity period; and (2) "data exclusivity," which is a period of time during which potential generic competitors may not rely on FDA findings of safety and efficacy of an earlier approved product necessary to support the generic application, which is typically enforced by a prohibition on the submission of generic applications for the duration of the exclusivity period. See Gitter, supra note 2, at 573 n.113 (defining "market exclusivity" and "generic exclusivity"); KoTLıKOFF, supra note 5, at 3, 5 (explaining what data and market exclusivities are); Mossinghoff, supra note 26, at 189 (explaining that a period of exclusivity during which a generic version of a drug cannot be approved is generally referred to as "data exclusivity"). Notably, the terms "market exclusivity" and "data exclusivity" have been defined rather loosely in the literature and sometimes have different meanings. See, e.g., Gitter, supra note 2, at 572 n. 108 (referring to "data exclusivity" as the period during which the FDA cannot approve an Abbreviated New Drug Application (ANDA) for a generic drug). The Hatch-Waxman Act establishes three market exclusivity periods (five years for NCE, three years for approval of a known drug for a new indication, and 180 days for approval of a generic version further challenging the patents related to the original drug) and a data exclusivity period of four to five years. See 21 U.S.C. $\$ \$ 355(\mathrm{j})(5)(\mathrm{F})(\mathrm{ii})-$ (iv) (2006).

68. See supra note 4. 
approval of generic versions of biologics. ${ }^{69}$ As could be expected, some of these proposals are more favorable to generic manufacturers while others better represent the interests of developers of original biological products. ${ }^{70}$ Yet almost all of the proposals mandate the institution of some statutory exclusivity periods in original biologics, and especially a market exclusivity period of twelve to fifteen years. ${ }^{71}$

The reoccurrence of a twelve-year period in many of the proposals is not a coincidence. Rather, it is the result of a perception that "the effective patent life for pharmaceuticals-the time remaining following FDA approval-is approximately eleven to twelve years." 72 Thus, an exclusivity period

69. See supra note 3. Some prominent proposals for the institution of a regulatory pathway for approval of generic versions of biologics include Affordable Health Care for America Act, H.R. 3962, 111 th Cong. $\$ \$ 2575-77$ (2009) (AHCAA) (highly similar to BPCIA); Biologics Price Competition and Innovation Act of 2009, H.R. 3590, 111 th Cong. $\S \S 7001-02$ (2009) (BPCIA); Patient Protection and Affordable Care Act, H.R. 3590, 111 th Cong. (2009) (PPACA) (the Senate vehicle for healthcare reform legislation, which was passed by the Senate by a Yay-Nay vote 60-39 on December 24, 2009); Promoting Innovation and Access to Life-Saving Medicine Act, H.R. 1427, 111 th Cong. (2009) (PIALSMA); Pathway for Biosimilars Act, H.R. 1548, 11 lth Cong. (PBA); Pathway for Biosimilars Act, H.R. 5629, 110th Cong. (2008) (PFBA); Access to Life-Saving Medicine Act, H.R. 1038, 110th Cong. (2007) (ALSMA); Biologics Price Competition and Innovation Act of 2007, S. 1695, 110th Cong. (2007) (BPClA 2007); Patient Protection and Innovation Biologic Medicines Act of 2007, H.R. 1956, 110th Cong. (2007) (PPIBMA).

70. For example, ALSMA and PIALSMA were considered more "pro-generic" as they generally set more lenient comparability standards, shorter exclusivity periods for original products, and better incentives for potential competitors to enter the market than "proinnovators" bills such as PPIBMA and PBA, which set stringent comparability standards and long exclusivity periods for developers of original biological products. See ALSMA, relevant sections to be added as PHSA $\$ \S 351(\mathbf{k})(4)$ and (10); PIALSMA, relevant sections to be added as PHSA $\$ \$ 351(\mathrm{k})(1)-(3),(5)(B)$ and (8) (11); PBA, relevant sections to be added as PHSA $\$ \S 351(\mathrm{k})(2)$, (4), (6) $-(7)$ and (9); and PPIBMA, relevant sections to be added as PHSA $\$ \$ 351(k)(2)(D)$ and $(3)-(6)$.

71. Under PPIBMA, developers of original biologics would have received exclusivity periods of 12 to 15 years; under BPCIA 2007, BPCIA, and AHCAA, 12 to 12.5 years; under PFBA and PBA, 12 to 14.5 years; and under PIALSMA, up to 6 years. The exception was ALSMA, which did not provide for exclusivity to developers of original biologics. See supra note 69 .

The length of exclusivity periods to be afforded to original biologics also was the subject of a heated debate regarding the optimum period of delay of generic entry into the market. See Gitter, supra note 2, at 613-16 (reviewing some of the proposals for exclusivity periods in original biological products). While it is beyond the scope of this Article to assess what is the "optimum period" of monopoly in the context of biologics, according to the Economic Review of the Patent System, "there will always be the possibility of very expensive developments that cannot be profitable even if a 30- or 50-year monopoly grant were promised." See EcoNOMIC Review of PATENT System, supra note 11, at 39.

72. See FTC REPORT, supra note 5, at vi ("The economic model put forth by pioneer drug manufacturers to justify [a 12- to 14-year exclusivity period] is based on the average time required to recoup the investment to develop and commercialize a typical biologic drug."); Gitter, supra note 2, at 616; Grabowski 2009, supra note 5, at 4 ("The average market exclusivity period for small molecule drugs in the United States is approximately twelve years."). But see BRILL, supra note 5, at 8; KoTlikofF, supra note 5, at 6. 
of about twelve years would presumably provide developers of original biologics with the assurance that the return on their investment would justify the time, money, and effort they expended in developing their products. ${ }^{73}$ Notably, the need for assurance in the case of biologics reflects an underlying assumption that patents alone cannot provide sufficient protection to the interests of developers of biological products. ${ }^{74}$

Eventually, after years of debate, on March 21, 2010, Congress enacted BPCIA as part of the healthcare reform $\operatorname{act}^{75}$ and on March 23, 2010, President Obama signed the act into law. ${ }^{76}$ Originally introduced on September 17, 2009 as part of the Senate's healthcare reform bill, BPCIA is the reintroduction of BPCIA 2007. ${ }^{77}$ BPCIA amends PHSA $\$ 351,{ }^{78}$ the FFDCA, and patent law by creating a regulatory pathway for the licensing of biological products "biosimilar to"79 or "interchangeable with" 80 an already approved biological product ("reference product"81). ${ }^{82}$ Once a biological

73. See Kelleher, supra note 57, at 256 ("Biologics cost more to produce than [smallmolecule] drugs, and thus a five-year market exclusivity similar to the Hatch-Waxman provision may not be long enough to incentivize the development of biologics. ... Some have suggested that a twelve-year market exclusivity for pioneer biologics would be optimal because traditional drugs generally have slightly under 12 years of market exclusivity due to patent protection."); Kelly \& David, supra note 3, at 139-40 ("[a] 12 to 14 year period of innovator exclusivity is not arbitrary: studies have shown that the point at which an innovator biological drug becomes profitable (the 'break-even' point) is between 12.9 and 16.2 years").

74. See Kelleher, supra note 57, at 256 (reviewing the flaws of patent protection for biological products and arguing that "while traditional new [small-molecule] drugs are generally protected by patents, biologics may be less effectively protected by the patent system"). See infra Part III.C.1.

75. Patient Protection and Affordable Care Act, 124 Stat. 119 (2010).

76. See Sheryl Gay Stolberg \& Robert Pear, Obama Signs Health Care Overhaul Bill, with a Flourish, N.Y. Times (Mar. 23, 2010) at A19, available at, http://www.nytimes.com/ 2010/03/24/health/policy/24health.html. As discussed earlier, less than one year later, in February 2011 , the same administration seems to have backed out of its earlier endorsement of BPCIA's twelve-year exclusivity period and is currently trying to limit this exclusivity period to seven years. See BUDGET, supra note 7, at 119.

77. BPCIA is almost identical to BPCIA 2007 introduced two years earlier by the late Senator Edward M. Kennedy and cosponsored by Senator Orrin Hatch and former Senator Hillary Rodham Clinton. See Thomas, LiBR, of ConG., http://thomas.gov (last visited Feb. 19, 2012).

78. Codified at 42 U.S.C. $\$ 262$ (2006).

79. Under BPCIA, the term 'biosimilar' or 'biosimilarity' means that "the biological product is highly similar to the reference product notwithstanding minor differences in clinically inactive components" and that "there are no clinically meaningful differences between the biological product and the [original] product in terms of the safety, purity, and potency of the product." See BPCIA $\$ 7002$ (b) (codified at 42 U.S.C.A. $\$ 262(\mathrm{i})(2)$ (West 2012)).

80. Under BPCIA, the term 'interchangeable' or 'interchangeability' means that "the biological product may be substituted for the reference product without the intervention of the health care provider who prescribed the reference product." See BPCIA $\$ 7002$ (b) (codified at 42 U.S.C.A. $\$ 262(\mathrm{i})(3)$ (West 2012)).

81. Under BPCIA, the term 'reference product' means the single biological product licensed under PHSA $\$ 351$ (a) (see supra Part II.A) against which a generic biological product is evaluated in an application submitted under BPCIA. See BPCIA $\$ 7002$ (b) (codified at 42 U.S.C. \$262(i)(4) (West 2012)).

82. BPCIA $\$ 7002$ (a) (codified at 42 U.S.C.A. $\$ 262$ (West 2012)). BPCIA sets up numerous elaborate conditions and requirements for the establishment of biosimilarity to or 
product is deemed "interchangeable with" a reference product, under BPCIA it may be substituted for the reference product without the intervention of the health care provider who prescribed the reference product. ${ }^{83}$

BPCIA sets a twelve-year market exclusivity period for original biologics $^{84}$ and a four-year data exclusivity period for the data submitted in support of the application for the original biologic. ${ }^{85}$ BPCIA also provides for a possible extension of the twelve-year market exclusivity and four-year data exclusivity by an additional six-month period for having the biological product tested and approved for use in pediatric populations. ${ }^{86}$ Thus, BPCIA creates market exclusivity periods for original biological products of up to

interchangeability with a reference product. See id. (codified at 42 U.S.C.A. $\$ \$ 262(k)(2)-(4)$ (West 2012)).

83. See supra note 80 . A determination of interchangeability is the essence of generic legislation and the prize sought after by generic applicants. Once made, the interchangeability determination facilitates the "interjection" of the generic product into the existing market for the original product and enables it to benefit from the reference product's client base.

84. BPCIA $\$ 7002$ (a) (codified at 42 U.S.C.A. $\$ 262(\mathrm{k})(7)(A)$ (West 2012)).

85. Id. (codified at 42 U.S.C.A. $\$ 262(\mathrm{k})(7)(B)$ (West 2012)). Under BPCIA, during this period, generic applicants may not submit applications for the approval of their versions of biologics biosimilar to original biological products. For further discussion of data exclusivity, see supra note 67.

This interpretation of the BPCIA sections relating to the exclusivities grant has been contested by a group of members of the House of Representatives who are identified as congressional supporters of the brand-name pharmaceutical companies. See Letter from Reps. Anna Eshoo, Jay Inslee, and Joe Barton to the Food \& Drug Admin. (Dec. 21, 2010), available at http://www.hpm.com/pdf/EIB\%20Ltr\%20FDA\%20DEC\%202010.pdf [hereinafter Eshoo letter]. The stance advanced in the Eshoo letter is that BPCIA "does not provide "market exclusivity' for innovator products. Rather, it provides data exclusivity for 12 years from the date of FDA approval." Id. The Eshoo letter does not directly explain the difference between the twelve-year and four-year exclusivities established under BPCIA but indirectly comments that "[BPCIA] does not prohibit or prevent another manufacturer from developing its own data to justify FDA approval of a similar of [sic] competitive product." Id. The positions taken in the Eshoo letter have been criticized as opposed to public policy as well as to the simple language of BPCIA. See, e.g., Letter from Sens. Sherrod Brown, John McCain, Charles Schumer, and Tom Harkin to Dr. Margaret Hamburg, Comm'r of the Food \& Drug Admin. (Jan. 24, 2011), available at http://brown.senate.gov/newsroom/press_releases/ release/?id=eae $9255 \mathrm{a}-246 \mathrm{e}-459 \mathrm{a}-826 \mathrm{~d}-0 \mathrm{bd} 117 \mathrm{~d} 7 \mathrm{~b} 9 \mathrm{a} 0$. Notably, as a post-enactment statement, the FDA is not obliged to give the positions expressed in the Eshoo letter substantial weight in its construction of the statutory language of BPCIA. See Massachusetts v. EPA, 549 U.S. 497, $530 \mathrm{n} .27$ (2007) (endorsing the position that "post-enactment legislative history is not only oxymoronic but inherently entitled to little weight"). Moreover, even if one is to ignore the non-conformity between the construction suggested in the Eshoo letter and the language of BPCIA itself, the Eshoo letter's statutory construction fails to explain the difference between the twelve-year and four-year statutory exclusivities. In other words, if the twelve-year statutory exclusivity is in fact data exclusivity, it appears to render the four-year statutory exclusivity established by the following subsection of BPCIA redundant. Accordingly, for at least this reason, it is unlikely that the FDA will adopt the interpretation proposed in the Eshoo letter.

86. BPCIA $\S 7002(\mathrm{~g})$ (codified at 42 U.S.C.A. $\$ 262(\mathrm{~m})$ (West 2012)). 
12.5 years and data exclusivity periods of up to 4.5 years. ${ }^{87}$ Importantly, the statutory exclusivities established under BPCIA do not guarantee exclusivity to an original developer of a biological product when a later developer seeks approval for its own version of the same biological compound for the same medical condition by conducting its own clinical trials. If the second developer independently takes its product through the FDA approval processes without seeking to rely on the approval of the earlier "original" biological product, it may also receive FDA approval and thus undermine the statutory exclusivities established under BPCIA ${ }^{88}$ BPCIA also establishes market exclusivity periods of twelve to forty-two months for a manufacturer of a first biological product approved as interchangeable with the reference product. ${ }^{89}$

Importantly, while the underlying rationales for market exclusivity under BPCIA and the five-year NCE statutory exclusivity under the HatchWaxman Act (on which the BPCIA market exclusivity is modeled) are similar, their function is different. In both cases, the intention is to provide developers of pharmaceutical products with sufficient incentives to invest in R\&D. ${ }^{90}$ However, while the five-year NCE statutory exclusivity is meant to work its effect where no incentives exist from a patent perspective (e.g., where the drug product contains a well-known active compound that is not patentable),,$^{91}$ the 12- to 12.5-year market exclusivity under BPCIA appears to have

87. The passage of BPCIA with its 12- to 12.5-year market exclusivity and 4- to 4.5year data exclusivity periods is at odds with the Obama Administration's outspoken opposition to such exclusivity periods, which it perceived as too long. See Letter from Nancy-Ann DeParle, Dir., Office of Health Reform and Peter Orszag, Dir., Office of Mgmt. and Budget to Rep. Henry A. Waxman (June 24, 2009), available at http://democrats.energycommerce. house.gov/Press_111/20090625/biologicsresponse.pdf (expressing the Obama Administration's position that an exclusivity period for original biological products of seven years "strikes the appropriate balance between innovation and competition").

88. This scenario may occur when the market for the biological product is large enough to financially justify taking the product through another, separate regulatory approval by the FDA rather than wait for the lapse of the applicable BPCIA statutory exclusivity periods.

89. BPCIA $\$ 7002$ (a) (codified at 42 U.S.C.A. $\$ 262(k)(6)$ (West 2012)). The determination of a market exclusivity period afforded to a generic manufacturer depends on several factors, including whether a patent infringement lawsuit was filed subsequent to the filing of the generic application for the approval of the biological product at bar, the outcome of such lawsuit, and the marketing status of such product. Id.

90. For the idea behind the NCE exclusivity established under the Hatch-Waxman Act, see The Legislative History of the Drug Price Competition and Patent Term RestoRATION ACT OF 198460 (Allan M. Fox \& Alan R. Bennett eds., 1987) ("The original Waxman Committee version ... would have allowed granting four years of market exclusivity only to new chemical entities that for technical or scientific reasons are unpatentable."); 130 Cong. Rec. 24,425 (1986) (statement of Rep. Waxman) ("the amendment provides a 5-year period of exclusive market life for drugs approved for the first time after enactment of the legislation. This provision will give the drug industry the incentives needed to develop new chemical entities whose therapeutic usefulness is discovered late when little or no patent life remains"). For the idea behind the market exclusivity established under BPCIA, see supra notes 72-73 and accompanying text.

91. See Fox \& Bennett, supra note 90. 
been devised as a "fallback" option to patents, serving as "insurance" in case they fail. ${ }^{92}$

BPCIA also creates an intricate dispute resolution scheme for patent disputes arising in relation to the submission of applications for approval of biological products as biosimilar to or interchangeable with a reference product. ${ }^{93}$ Under BPCIA, within twenty days from the acceptance of an application for a generic biologic by the FDA, the generic applicant is required, under a duty of confidentiality, to provide a copy of the application and additional information regarding the process used to manufacture the biological product to legal representatives of the reference product sponsor and other potential adversaries. ${ }^{94}$ Within sixty days after receipt of the information from the generic applicant, the reference product sponsor is required to (1) provide the generic applicant with a list of all patents for which the reference product sponsor believes a claim of patent infringement could reasonably be asserted against the generic applicant if it engaged in the making, using, offering to sell, selling, or importation of the generic biological product, and (2) identify which of these patents it would be prepared to license to the generic applicant. ${ }^{95}$ BPCIA then stipulates that within sixty days of receipt of the reference product sponsor's patent list, the generic applicant may (but does not have to) provide its own "counter-list" of patents with respect to which it believes a claim of patent infringement could reasonably be asserted by the reference product sponsor. ${ }^{96}$ For each patent on the reference product sponsor's list and the generic applicant's counterlist, the generic applicant is required to provide either "a detailed statement that describes, on a claim-by-claim basis, the factual and legal basis of the opinion of the [generic] applicant that such patent is invalid, unenforceable, or will not be infringed by the commercial marketing of the biological product" or a statement that it does not intend to begin commercial marketing before the date of patent expiry. ${ }^{97}$ Within sixty days of receipt of the generic applicant's detailed statement, the reference product sponsor is required, in

92. Proponents of long market exclusivity periods in biological products have described such exclusivity as an "insurance policy" in case patents would fail. See infra note 143 and accompanying text. In other words, rather than provide protection in addition to patents or in case patents cannot be obtained, market exclusivity under BPCIA is meant to provide "litigation-proof' protection to the interests of developers of biological products in case their patents fall short.

An interesting question, which exceeds the scope of this Article, is whether statutory exclusivities could be classified as proprietary rights-possibly a new kind of property-and the implications of such classification.

93. BPCIA $\$ 7002$ (a) (codified at 42 U.S.C.A. $\$ 262$ (l) (West 2012)).

94. Id. (codified at 42 U.S.C.A. $\$ 262(1)(1)-(2)$ (West 2012)).

95. Id. (codified at 42 U.S.C.A. $\$ 262(\mathrm{I})(3)(\mathrm{A})$ (West 2012)). BPCIA stipulates that a reference product sponsor would be unable to sue for infringement of patents that it did not include on its list. Id. (codified at 35 U.S.C.A. $\$ 271$ (e)(6) (West 2012)).

96. Id. (codified at 42 U.S.C.A. $\$ 262(1)(3)(B)($ West 2012$)$ ).

97. Id. 
turn, to provide a "counter-detailed statement" explaining, for each patent claim addressed in the generic applicant's detailed statement, "the factual and legal basis of the opinion of the reference product sponsor that such patent will be infringed by the commercial marketing of the biological product" as well as a response to the generic applicant's statements of invalidity and unenforceability. ${ }^{98}$ Upon completion of the above exchanges of information and legal positions, BPCIA mandates that the parties must enter pre-litigation negotiations in order to decide, within fifteen days, which patents, if any, will be the subject of an infringement action. ${ }^{99}$

BPCIA also addresses other potential litigation scenarios. First, BPCIA stipulates that within thirty days of the exchange of patent lists between the reference product sponsor and generic applicant or of the date of reaching an agreement on patents that would be the subject of an infringement action, the reference product sponsor is required to bring a patent infringement action with respect to the patents under dispute. ${ }^{100}$ Second, at least 180 days prior to a first commercial marketing of a generic biological product, BPCIA requires the generic applicant about to launch the product to provide notice of the planned launch to the reference product sponsor, which may then seek to enjoin the generic applicant from moving ahead with the launch. ${ }^{101}$ Under BPCIA, such an injunction would hold until a court decision on pending issues of patent validity, infringement, and enforceability arising with relation to patents included on any patent list previously exchanged by the parties under BPCIA. ${ }^{102}$ Third, BPCIA addresses declaratory judgment actions and mandates that if the generic applicant sent the reference product sponsor a copy of the generic product application as required, then declaratory judgment actions would be available to the parties only once the 180-day notice of commercial marketing is provided to the reference product sponsor. ${ }^{103}$ However, the reference product sponsor may bring such actions even earlier if the generic applicant fails to comply with other requirements set by BPCIA. ${ }^{104}$

The next part of this Article will compare the current legal regimes under patent law and BPCIA as they pertain to biological products and ex-

98. Id. (codified at 42 U.S.C.A. \$262(1)(3)(C) (West 2012)).

99. Id. (codified at 42 U.S.C.A. $\$ 262(1)(4)$ (West 2012)). If the parties fail to reach an agreement, BPCIA sets up an elaborate mechanism to decide on the number and identity of such patents that would be the subject of such an infringement action. Id. (codified at 42 U.S.C.A. $\$ 262(1)(5)$ (West 2012)).

100. BPCIA $\$ 7002$ (a) (codified at 42 U.S.C.A. $\$ 262$ (1)(6) (West 2012)). Under BPCIA, if the reference product sponsor fails to assert certain patents within that time frame, then a reasonable royalty is the sole and exclusive remedy that a court may grant if it finds that such patents were infringed. $I d$. (codified at 35 U.S.C.A. $\$ 271$ (e)(6) (West 2012)).

101. BPClA $\$ 7002$ (a) (codified at 42 U.S.C.A. $\$ 262(1)(8)$ (West 2012)).

102. Id. (codified at 42 U.S.C.A. $\$ 262(1)(8)$ (B) (West 2012)).

103. Id. (codified at 42 U.S.C.A. $\$ 262(\mathrm{I})(9)$ (West 2012)).

104. Id. (codified at 42 U.S.C.A. $\$ 262(\mathrm{I})(9)(\mathrm{B})-(\mathrm{C})$ (West 2012)). 
amine the question of whether there is actually a need and justification for both types of protection in the context of biologics.

\section{Patents vs. Statutory Exclusivities in Biological Products: Timeline, Public Policy, and the INTERESTS OF BIOLOGIC LICENSE HOLDERS}

\section{A. Patents vs. Statutory Exclusivities in Biologics: A Timeline}

The R\&D and approval of biologics, from the first synthesizing of the biologic or a closely related compound through the approval of the BLA by the FDA, ${ }^{105}$ is a long process that typically spans more than a decade. ${ }^{106}$ Although all development projects are different, a rough estimate of a typical timeline for the development of a biological product consists of about 4 to 5 years of preclinical studies, ${ }^{107} 6$ to 9 years dedicated to clinical trials prior to the submission of a BLA, ${ }^{108}$ and another 12 to 16 months for the

105. One may also view the development of drugs and biologics as an ongoing process that includes further R\&D subsequent to marketing approval by the FDA. See Glossary of Clinical Trials Terms, CliniCALTRIAls.gov (Mar. 18, 2008), http://clinicaltrials.gov/ct2/info/ glossary\#phaselv.

106. Grabowski 2008, supra note 5, at 481 (illustrating the length of the development process of biologics with the example of the anti-cancer biologic Avastin, whose active compound, bevacizumab, took about fifteen years to develop and have approved by the FDA); Vernon et al., supra note 5, at 68 ("[b]ringing a single new product to market requires huge sums of investor capital and often takes well over a decade"); see also infra Part III.B (discussing my finding that the average number of days between the filing of the first patent application pertaining to a biological product, which is indicative of R\&D activities, and FDA approval of the product as pertaining to the seventy-nine biological products listed in Table 1 is 3728 days, or about 10.2 years).

107. E.g., Dennis S. Fernandez et al., The Interface of Patents with the Regulatory Drug Approval Process and How Resulting Interplay Can Affect Market Entry, in INTELLECTUAL Property Management in Health and Agriculture Innovation: a Handbook of Best PraCTICES (Anatole Krattiger et al. eds, 2007) ("[p]reclinical studies take an average of five years"); DiMasi \& Grabowski, supra note 56, at 475 tbl.3 (estimating that the time spent on preclinical studies of candidate biological products is about fifty-two months); Grabowski 2008, supra note 5, at 486 (stating that preclinical R\&D requires four to five years to produce several lead candidates). "Preclinical studies" are the earliest phase in drug development beginning right after the identification of a candidate-compound and concluding with the filing of an investigational new drug application (IND) with the FDA. This step normally includes in vitro and animal testing of the tested compound, pharmacodynamic studies, and more. Fernandez et al. at 966 (describing the discovery phase and preclinical studies of new drugs). Once an IND is submitted, unless the FDA places a hold on the IND, the applicant may begin clinical trials after thirty days. FDA Investigational New Drug Application Rule, 21 C.F.R. $\$ \$ 312.40(b)(1), 312.42(2011)$. About $85 \%$ of all drugs for which an IND is filed are eventually approved for testing in clinical trials. Fernandez et al. at 966.

108. The clinical trials stage of development is typically divided into three phases preceding the submission of a Biologic License Application (BLA). Phase I involves testing the candidate compound on humans for the first time for safety, determination of a dosage range, and identification of potential side effects, and includes about twenty-eighty healthy individuals. Phase II involves testing the drug/biologic on about one hundred to three hundred volunteers 
FDA to process and decide on the BLA. ${ }^{109}$ In sum, the development of a biological product typically takes 11 to 15.5 years. ${ }^{110}$

Based on the abovementioned time frames and in view of the fact that statutory exclusivities in biologics only "kick in" upon FDA approval, BPCIA dictates that (1) manufacturers of generic versions of biologics can only file applications for generic versions of biologics fifteen to twenty years from the inception of development of the original biological product, and (2) the FDA may only approve such applications after twenty-three to twenty-eight year'; from the inception of development of the original biologic. ${ }^{1 / 1}$

Viewing the abovementioned time frames from a patent perspective, it is important to acknowledge several additional milestones. First, biologics may be and often are the subject of numerous patents that typically cover (1) specific biological compounds, namely the purified active biological compounds themselves (most frequently, proteins), their precursors, possible metabolites and other derivatives, ${ }^{112}(2)$ processes of making these com-

having the condition that the drug/biologic is meant to treat to determine if it is effective and to further evaluate its safety. Phase III varies greatly for different drugs/biologics but normally involves one thousand to three thousand patients and is meant to confirm the drug/biologic's effectiveness, monitor side effects, compare the drug to commonly used treatments, and collect information that will allow the drug/biologic to be used safely. See 21 C.F.R. $\$ 312.21$ (2011); Understanding Clinical Trials, CliniCalTrials.gov (Sept. 20, 2007), http://clinicaltrials.gov/ct2/info/understand\#Q18; Telephone Interview with Food \& Drug Admin. Ctr. for Biologics Eval. \& Res, representative (Feb. 23, 2010) [hereinafter CBER Interview] (on file with author). Notably, estimates of the length of the different phases of clinical trials vary among different commentators. Phase I could take, on average, from I to 3 years; Phase II: 2 years; and Phase III: 3 to 4 years. Fernandez et al., supra note 107, at 966. According to an unofficial estimate by a CBER staff-member, Phase I takes about 1 year on average; Phase II about 2; and Phase III, while varying greatly depending on the amount of testing done by the applicant, on average, about 3 years. CBER Interview. Grabowski and DiMasi estimate that clinical trials take an average of 6.8 years. DiMasi \& Grabowski, supra note 56, at 473 fig. 2 (estimating the time spent on clinical development of biologics at about eighty-two months).

109. DiMasi \& Grabowski, supra note 56, at 473 fig.2 (estimating the time spent on approval of biologics at about sixteen months); CBER Interview, supra note 108.

110. This calculation is based on adding the estimated 4 to 5 years of preclinical studies, 6 to 9 years of clinical trials, and the 1 to 1.33 years it takes the FDA to approve BLAs, and then rounding the result ( 11 to 15.33 years) to the closest half-year increment.

111. These calculations are based on adding the estimated 11 to 15.5 years it takes to put a typical biologic on the market to the 4 to 4.5 years of data exclusivity and to the 12 to 12.5 years of market exclusivity under BPCIA.

112. See Amgen, Inc. v. Chugai Pharm. Co., 927 F.2d 1200, 1206 (Fed. Cir. 1991) (holding that naturally occurring DNA sequences constitute patentable subject matter when "purified and isolated" as compared to their natural form); Parke-Davis \& Co. v. H.K. Mulford Co., 189 F. 95 (S.D.N.Y. 1911), aff'd in part and rev'd in part, 196 F. 496 (2d Cir. 1912) (holding that the purified form of adrenalin-a compound existing in the human body-was patentable because the purification process transformed it into drug and therefore into "a new thing commercially and therapeutically"). But see Ass'n for Molecular Pathology v. U.S. Patent \& Trademark Office, 702 F.Supp.2d 181 (S.D.N.Y. 2010), rev'd in part, 653 F.3d 1329 (Fed. Cir. 2011), cert. granted, judgment vacated, matter remanded, I1-725, 2012 WL 986819 (U.S. Mar. 26, 2011). 
pounds, ${ }^{113}$ (3) formulations containing the compounds, ${ }^{114}$ and (4) methods of using the biological compound in the treatment of illnesses. ${ }^{115}$ Since the natural course of development of most biologics first involves the identification, making, and isolation of a biologic having therapeutic properties (not necessarily in that order), the first patent applications commonly seek to claim the biological active pharmaceutical ingredient ("API"), closely related compounds, and methods of making them, and are filed very early in the development process, ${ }^{116}$ typically between the time immediately pursuant to the identification of the biological API and right before the beginning of clinical trials in human subjects. ${ }^{117}$ In other words, if the beginning of the R\&D efforts is marked as the "zero" time-point and clinical trials normally begin after four to five years of preclinical studies, then the filing of the first patent application pertaining to the biological product would normally occur between "development years" one and four to five (depending on the length of the preclinical trials stage). ${ }^{118}$ Patents generally expire twenty years from

113. See Gitter, supra note 2, at 610 (reviewing the types of patents available to developers of biological products).

114. See id. Formulations are the compositions of the final product, namely the active pharmaceutical ingredient (API) and different pharmaceutically inactive ingredients (also known as "excipients") having certain functions in the composition, e.g., stabilization, dissolution, adjustment of $\mathrm{pH}$, and filling.

115. See id.

116. Cf. Ariad Pharm., Inc. v. Eli Lilly \& Co., 598 F. 3d 1336 (Fed. Cir. 2010) (essentially abolishing method claims directed to mechanisms of action per se, namely as standalone claims independent from sufficient disclosure of compounds that are used to achieve the desired action as part of the 35 U.S.C. $\$ 112$ \1 written description requirement).

117. See In re 318 Patent Infringement Litigation, 583 F.3d 1317, 1389 (Fed. Cir. 2009) ("results from animal tests or in vitro experiments may be sufficient to satisfy the utility requirement"); In re Brana, 51 F.3d 1560, 1567-68 (Fed. Cir. 1995) (holding that an antitumor compound does not necessarily have to be tested in vivo to fulfill the utility requirement under 35 U.S.C. $\$ 101$ and that in vitro tests using cell-line models may be sufficient; stating that "[t]he stage at which an invention in [the field of biologics] becomes useful is well before it is ready to be administered to humans"). This estimated time frame is confirmed by my findings that the average time period between the filing of the first patent applications pertaining to biological products and their approval by the FDA is about 3728 days, or 10.2 years. See supra note 106 and accompanying text. Deducting the estimated 6 to 9 years of clinical trials and 1 to 1.33 years of processing of BLAs, it appears that the time frame for filing of the first patent applications covering biological products is about 0 to 3 years prior to the beginning of clinical trials, cert. granted, judgment vacated, matter remanded, 11-725, 2012 WL 986819 (U.S. Mar. 26, 2012).

A possible explanation of this patent filing strategy is that once a compound enters the stage of human trials, it is exceedingly difficult to keep it as a trade secret and the early filing is meant to preserve the developer's prospects of monopoly in any product that may result from its R\&D efforts. Another explanation is that early filing of patent applications mitigates pressure from in-house scientists to be allowed to publish their scientifically significant findings in scientific literature.

118. Notably, the first patent application is not necessarily the first submission to the USPTO, which is frequently of a provisional application containing little more than preliminary data and a rudimentary concept of the invention and whose purpose is merely to "buy" the inventors another year for further development of their invention prior to the filing of a 
the filing date of the original application. ${ }^{119}$ Thus, as a general proposition, the primary patents ${ }^{120}$ pertaining to biological products would be set to expire between "development years" twenty-one and twenty-five, ${ }^{121}$ whereas the market exclusivity period pertaining to the products covered by these patents would expire around "development years" twenty-three to twentyeight.

When comparing the term of statutory exclusivities to the term of primary patents, it is necessary to take into account patent term extensions that one primary patent per FDA-approved product may receive under 35 U.S.C. $\S 156 .{ }^{122}$ If we make the most patent-term-favorable assumptions that virtually all first primary patents (i.e., the first primary patent to issue for any given biological product) would merit an extension of 4 to 5 years, ${ }^{123}$ then it is possible to argue that for any biological product there would be one patent whose term would be extended 1.5 to 2 years beyond the expiration of the 12- to 12.5-year market exclusivity period. ${ }^{124}$ Thus, while generally the first

non-provisional application. See 35 U.S.C. $\$ \$ 111(\mathrm{~b}), 119(\mathrm{e})$ (2006). For further discussion of provisional applications, see Provisional Application for Patent, U.S. PATENT \& TRAdemark OFFICE (June 2, 201 1), http://www.uspto.gov/patents/resources/types/provapp.jsp.

119. See 35 U.S.C. $\$ 154$ (2006). This expiration date may be adjusted to compensate for delays in the processing of the application by the USPTO, a filing of a terminal disclaimer with respect to the issued patent, and time lost during the examination and approval of the BLA by the FDA. See infra Part III.B.

120. For purposes of the discussion herein, a "primary patent" is defined as a patent issued from one of the first patent applications to be filed early in the R\&D of the biological product and covering, typically, the biological API itself, its manufacturing, and the first known methods of using it.

121. This calculation is based on adding the estimated one to four years from the onset of development-which is the period during which one could assume most early patents pertaining to a biological product would be filed-to the twenty-year patent term.

122. The term of patents pertinent to biological products "shall be extended by the time equal to the regulatory review period for the approved product," 35 U.S.C. \$156(c) (2006), up to a total period of fourteen years from the date of approval of the biological product but not exceeding five years, whereas the "regulatory review period" is calculated as half the time in which the product was in clinical trials, plus the period it took the FDA to review and approve the BLA. See 35 U.S.C. $\$ \$ 156(\mathrm{a})(4),(\mathrm{c}),(\mathrm{f})(2)(\mathrm{A}),(\mathrm{g})(1),(\mathrm{g})(6)(2006) ; 21$ U.S.C. $\$ 355(\mathrm{i})$ (2006); 42 U.S.C. $\$ 262(\mathrm{j})$ (2006); see also Mossinghoff, supra note 26, at 190 (reciting and explaining the abovementioned patent term extension provisions and stating that " $[\mathrm{t}] \mathrm{he}$ patent term restoration part ... in title 35 of the United States Code ... [consists of] very long, very complicated provisions .... The length of the exclusivity periods are strictly arbitrary legislative numbers pulled out of the air.').

123. Given the length of clinical trials of biologics and the average 12 to 16 months needed for FDA review of BLAs, it is prudent to assume that the majority of biological products would merit the maximum patent term extension of half the clinical trials' period plus the time needed for FDA review of the application up to a maximum of 5 years. Basing the calculation on the estimated times brought herein, the term extension could be roughly estimated as equal to half of 6 to 9 years plus 1 to 1.33 years, namely, 4 to 5.83 years. Given the upper limit of 5 years, a typical patent term extension period would be 4 to 5 years.

124. Since under 35 U.S.C. \$ 156 patent term extension cannot extend the patent term beyond 14 years from the date of FDA approval of the product and the statutory market exclusivity under BPCIA extends for 12 to 12.5 years from that date, then, arguably, no patent term 
patents covering biological products would expire within 21 to 25 years from the onset of development, under the above patent-term-favorable assumptions, one of the primary patents would expire within about 25 to 30 years from that date. ${ }^{125}$ However, in reality not all primary patents are entitled to a patent term extension, as in some instances the term of primary patents already extends beyond 14 years from the date of FDA-approval. Thus, as I will argue in the next section, even with patent term extension, primary patents are expected to expire, on average, around 5 to 11 months after the expiration of the 12- to 12.5-year market exclusivity period under BPCIA. ${ }^{126}$

\section{B. Patent Term vs. Market Exclusivity for Biologics: A Case Study}

In order to test the validity of the above time frame estimates and compare the term of patents pertaining to biological products with the term of market exclusivity that such products will receive under BPCIA, I calculated (1) the term of the first-to-issue primary patents ${ }^{127}$ pertaining to seventy-nine already-approved biological products listed in Table $1^{128}$ and (2) the hypothetical dates in which the market exclusivity in these products would have expired had these products been subject to BPCIA. ${ }^{129}$ Based on these dates, for each of the first-to-issue primary patents identified, I calculated the time

could be extended more than 2 years beyond the expiration of a 12-year market exclusivity or 1.5 years beyond the expiration of a 12.5 -year market exclusivity.

125. This calculation is based on adding the estimated 4 to 5 years of patent term extension to the 21- to 25-year patent term from the inception of development. The calculation would be slightly different if we were to add 1.5 to 2 years to the statutory exclusivity period of 23 to 28 years, resulting in a similar patent term extending from 25 to 29.5 years from the beginning of development.

126. See infra Part III.B.

127. See infra Table 1, note 246, and accompanying text. The patent term calculation was based on the various sections of patent law and includes any patent term extensions awarded to patents under the Hatch-Waxman Act as listed in the USPTO Listing of Patent Term Extensions under 35 U.S.C. \$156, Patent Terms Extended Under 35 USC \$156, U.S. Patent \& Trademark OfFice (Mar. 4, 20i0), http://www.uspto.gov/patents/resources/terms/ 156.jsp, and any patent term adjustments as reflected on the face of the patents and in the patent information available through the USPTO Patent Application Information Retrieval System (PAIR), Patent Application Information Retrieval, U.S. PATENT \& TRADEMARK OFFICE, http://portal.uspto.gov/external/portal/pair (last visited Feb. 8, 2012).

128. The list consists of seventy-nine biological products for which primary patents could be identified, including sixteen out of the twenty-four best selling biological products in 2008 and excluding insulin and human growth hormone (hGH) products, for which generic (or "follow-on") versions have already been approved by the FDA. See Top Twenty Biologics 2008, R\&D Pipeline News SPECIAL Edition 1/2009 (LaMerie Business Intelligence), Mar. 2009, at 3-6 (including Enbrel, Remicade, Epogen, Rituxan, Avastin, Herceptin, Aranesp, Neulasta, Lantus, Avonex, Lucentis, Erbitux, Betaseron, Neupogen, Cerezyme, and Synagis). The above selection criteria for the analyzed sample of seventy-nine biological products might admittedly reflect selection biases. At the same time, it is difficult to determine what would be considered a "representative sample" of biological products for the purpose of calculating the average length of primary patent life covering such products.

129. See infra Table 1 , note 247 , and accompanying text. 
from expiration of the patent to the end of the twelve-year market exclusivity in the product and then, based on the results received, the average time for the seventy-nine products between the end of the twelve-year market exclusivity and the expiration of the primary patent. ${ }^{130}$ According to these calculations, the average time difference between the end of the twelve-year market exclusivity in a biological product and the expiration of the firstissued primary patent is about 327 days. ${ }^{131}$ In other words, the average term of the first identified primary patents pertaining to the seventy-nine biological products listed in Table 1 extends about eleven months beyond the end of the twelve-year market exclusivity period in these products. If we add the extension of six months to the market exclusivity period (making it 12.5 years) for having a product tested and approved for pediatric use, ${ }^{132}$ the average term of the first identified primary patents pertaining to the seventy-nine biological products listed in Table 1 would extend about five months beyond the end of the market exclusivity period in these products.

In conclusion, patents in the family of the original application ${ }^{133}$ could be expected to expire within roughly twenty-one to twenty-five years from the onset of the development of the biological product ${ }^{134}$ with one more patent expected to expire, on average, around five to eleven months after the period of market exclusivity under BPCIA. Thus, arguably, based on the above calculations, the market exclusivity period under BPCIA would keep competition out of biologic markets, on average, for five to eleven months less than the average monopoly period afforded by primary patents on inventions pertaining to the biological product. ${ }^{135}$ These conclusions may be illustrated graphically as follows:

130. See infra Table 1 , note 249 , and accompanying text. For purposes of the calculations herein, I refrained from making any assumptions regarding the potential addition of six months of market exclusivity for experimentation in pediatric populations. See supra note 86 and accompanying text.

131. See infra Table 1 , note 249 , and accompanying text. The average number of days between FDA approval and the expiration of the first-to-issue primary patent listed for each of the seventy-nine products is calculated by adding the number of days for all seventy-nine products and then dividing by seventy-nine.

132. See supra notes 86-87 and accompanying text.

133. A "patent family" includes all divisional, continuation, and continuation-in-part applications (and issued patents thereof) stemming from a certain earlier parent application. See U.S. Patent \& Trademark Office, Manual of Patent Examining Procedure (MPEP) $\$ \$ 201.04-201.08$ (8th ed. 2001), available at http://www.uspto.gov/web/offices/pac/ mpep/index.htm (referencing the latest revision from July 2010).

134. See supra note 121 and accompanying text.

135. These conclusions are in accord with the rationale behind the twelve-year market exclusivity period for new biological products under BPCIA, namely, ensuring that original product developers are able to monopolize their products for a period at least as long as that which patents would have afforded them. See supra notes 72-74 and accompanying text. Importantly, these conclusions are only valid with respect to primary patents covering the "first wave of inventions" rather than to patents covering inventions resulting from continuing research. 


\section{Figure 1 \\ Patent Term vs. Statutory Exclusivities in Biologics}

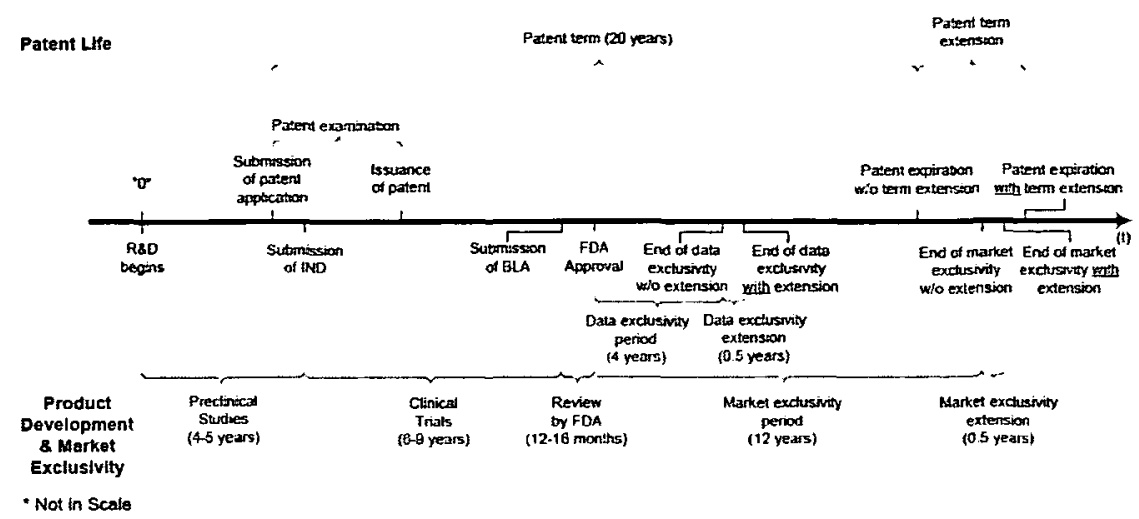

These conclusions invite the question: what is the justification (if any) for the mostly overlapping protection of biological products under both BPCIA and patent law ${ }^{136}$ and what implications might there be to this "double-tiered" protection?

\section{Patents vs. Statutory Exclusivities for \\ Biologics: A Public Policy Perspective}

Comparing the rationales for granting statutory exclusivities with the patent theories discussed earlier, it appears that the reasoning behind both types of monopoly is quite similar if not identical, especially in the context of biologics. In a nutshell, the incentive-to-disclose and incentive-to-invent patent theories emphasize patents' functional role of incentivizing the disclosure of existing inventions and the pursuit of further R\&D activities leading to more inventions. ${ }^{137}$ Taking a closer look at the rationales for granting statutory exclusivities reveals a highly similar picture. The purpose of statutory exclusivities in the context of pharmaceuticals is to ensure that developers of original biologics are able to reap the fruits of their investments, thereby maintaining sufficient incentive-to-invent. ${ }^{138}$ Thus, arguably,

136. Disagreements regarding the length of patent protection are not uncommon given the complexity of patent law and the dependence of such calculations on numerous factors (e.g., the timing of filing of patent applications, the ramifications of various different types of extensions, and the prosecution of the patents). However, even slight changes in the term of any particular patent do not change the fact that the effective result of BPCIA is the institution of "double monopoly protection" for biologics.

137. See supra Part I.A.

138. See Kelleher, supra note 57, at 255 ("[The New Chemical Entity five year market exclusivity provision of the Hatch-Waxman Act] was meant to alleviate concerns that a generic pathway would prohibit innovators from realizing the benefits of their investments."); Tam, 
both patent and statutory exclusivities regimes (1) recognize developers' right to benefit from the fruit of their labor by creating means to exclude others from using the biologics they developed; ${ }^{139}(2)$ enable only the developers to reap profits from the biological products for a certain period of time; and (3) encourage and require developers of biologics to disclose to the public the products they develop and their uses as a pre-requisite to the developers' ability to receive exclusivity in their products. ${ }^{140}$ Accordingly, at least from a functional perspective, in the context of bi slogics, both patents and statutory exclusivities seek to achieve the same purpose and incentivize essentially the same behavior by inventors, investors, and developers.

The goal of technological advancement in the area of biological products could therefore be served by affording any kind of effective exclusivity guaranteeing sufficient profits to investors in $R \& D$ regardless of whether the product of such R\&D would eventually fit in the strict mold of a "patentable invention" under patent law. ${ }^{141}$

\section{Why Patents May Not Provide Sufficient Protection to the Interests of Developers of Biological Products}

The similarity of purpose and effect of statutory exclusivities and patent protection begs the question: why, if at all, is there a need for statutory ex-

supra note 46 , at 553 ("[T]he policy behind marketing exclusivities is to incentivize pharmaceutical research entities to engage in ambitious, cutting-edge research for the development of new drugs and to develop greater understanding about existing drugs.'); see also Grabowski 2009 , supra note 5, at 2 (recognizing that both patents and statutory exclusivities "address the need for innovators to have some period of returns before imitators can enter the market with an abbreviated filing").

139. In the case of patents, these means to exclude take the form of letters of patent enforceable by courts while in the case of statutory exclusivities they entail direct exclusion of potential competitors from the market for the particular biological product.

140. In the context of patents, disclosure takes place as part of patents' specifications. In the context of statutory exclusivities, disclosure occurs in the submission of some publicly available information as part of the BLA. Thus, the incentive-to-disclose rationale is inherent to the context of biologics for the reason that it is impossible to commercialize a biologic without prior approval by the FDA, which can only be granted subsequent to the submission of information regarding the product, including such publicly available information about the nature of the product and its intended medical uses. In other words, the incentive to disclose information to the public about biologics exists regardless of any additional exclusivity that may or may not be granted to the products' developers under patent law. Interesting questions remain, however, as to the extent of disclosure incentivized by patent and statutory exclusivities regimes with respect to manufacturing "know-how" and actual clinical data. For further discussion of these issues, see infra Part III.C.2.b and note 159 gI 2 and accompanying text.

141. As early as the 1950s, the Economic Review of the Patent System already recognized that it is "monopoly grant" in general, rather than patent monopoly in particular, that is necessary to incentivize the risks taken by financiers of industrial application of certain technology. See Economic Review of PATENT System, supra note 11, at 36-37 "The risks involved [in investment in technological $R \& D$ ] may be too great to be undertaken except under the shelter of a monopoly grant."). According to this logic, statutory exclusivities would be no different than patents from the incentive-to-invest point of view. 
clusivities in addition to patents? The most frequently cited justification is that patents alone are insufficient to protect proprietary interests in biological products. ${ }^{142}$ Viewed in this light, statutory exclusivities for biologics are sometimes referred to as "insurance policies" meant to protect the interests of developers of biological products where patents might fail to do so. ${ }^{143}$ There are several reasons why patents insufficiently protect the interests of developers of biological products and why developers prefer a statutory exclusivities regime such as BPCIA.

\section{a. Patent Acquisition and Enforcement Is Expensive, Yet Patents Provide a Limited Degree of Legal Protection for Biologics}

The patent system suffers from inherent shortcomings that make the investment in obtaining and enforcing patents a risky and highly uncertain proposition. The securing and enforcement of patent rights involves a long and tedious via dolorosa of intricate (and expensive) proceedings. Patent acquisition requires compliance with complicated legal criteria such as "novelty," "utility," and "non-obviousness," as well as a plethora of procedural and technical requirements stemming from centuries of litigation and patent prosecution. ${ }^{144}$ This complexity, when combined with the high rate of patent invalidation in litigation, ${ }^{145}$ creates uncertainty regarding the outcome of patent litigation and undermines the ability of developers and entrepreneurs to

142. See infra Parts III.C.1.a-d. Representatives of original biologics developers have made forceful assertions regarding the need for both statutory exclusivities and patent protection in biological products. See, e.g., BIO WhITE PAPER, supra note 2, at 22, 37 (arguing that "[a]s was the case in the Hatch-Waxman Act, it will be important to consider patent exclusivity, along with market exclusivity provided through the regulatory approval mechanism, as an integral part of the follow-on biologic approval framework," and that "any statutory pathway for the approval of follow-on biologics must contain an appropriate mix of patent-based and market/data-based exclusivity to ensure effective market protection to incentivize investment and innovation").

143. According to Grabowski and DiMasi, the purpose of statutory exclusivities is to provide investors "with an 'insurance policy" against the potential failings of patent protection for biologics." BIO DATA Exclusivity Position PAPER, supra note 5, at 4 ("[A] 14-year period of data exclusivity serves essentially as an insurance policy that provides the innovator with some certainty of protection."); Grabowski et al., supra note 5, at 4; Grabowski \& DiMasi 2009, supra note 5, at 8 ("[f]rom the standpoint of innovative firms, [statutory] exclusivity protection provides a back-up or insurance policy to the patent system").

144. See ECONOMic Review of PATENT System, supra note 11, at 6 ("[B]ut just what an 'invention' is, and when it can be regarded as 'novel' and 'useful,' is not self evident. The questions of the 'correct' criteria of utility, novelty, and invention have been answered in many different ways, and the courts of several countries are constantly reconsidering earlier answers."). For a good example of the intricacy of patent prosecution proceedings one need only consider the volume of the USPTO's Manual of Patent Examining Procedure (MPEP), see USPTO, supra note 133.

145. See Michael Meehan, Increasing Certainty and Harnessing Private Information in the U.S. Patent System: A Proposal for Reform, 2010 Stan. TeCh. L. Rev. 1, 1 (2010) ("Nearly half of litigated patents are invalidated."). 
rely on patents as a dependable means of securing their investment. ${ }^{146}$ Machlup described the shortcomings of patents as follows:

The patent system lacks logic. It postulates something called "invention' but in fact no satisfactory definition of "invention" has even appeared, and the courts, in their search for guiding rules, have produced an almost incredible tangle of conflicting doctrines. This confusion has led to extensive and costly litigation. Its critics have described the patent right as merely "something which has to be defended in the courts" and, because it may put the individual inventor at a disadvantage against the larger corporations, as "a lottery in which it is hardly worthwhile taking out a ticket." The system, too, is wasteful. It gives protection for 16 years (or thereabouts) whilst in fact over nine-tenths of the patents do not remain active for the whole of this period ... It is almost impossible to conceive of any existing social institution so faulty in so many ways. It survives only because there seems to be nothing better. ${ }^{147}$

All of these shortcomings of the patent system appear to be further exacerbated in the context of pharmaceuticals in general and biologics in particular. ${ }^{148}$ First, as I will later argue, due to some particular characteristics, biologics are subject to especially high barriers to patentability not existing in other areas of technology. ${ }^{149}$

Second, the patent dispute resolution framework established by BPCIA would necessitate an even higher investment of resources by all of the parties involved. ${ }^{150}$ As discussed earlier, BPCIA sets up a highly complicated

146. See Grabowski 2008, supra note 5, at 482 (warning that "if the relatively few large success[ful biological products that make it through development and approval] experience increased uncertainty due to patent challenges and the potential for early entry of generic versions, higher risk-adjusted rates of return will be demanded by venture capital firms as well as in initial public offerings and secondary offerings in public markets, yielding fewer candidates that meet this standard"); Grabowski \& DiMasi 2009, supra note 5, at 9 ("Uncertainty about recoupment periods and the ability to earn a risk adjusted return on particular new product candidates will result in fewer of these candidates being taken forward into development.").

147. ECONOMIC Review of PATENT SySTEM, supra note 11, at 44 (emphasis added). Despite the fact that the Economic Review of the Patent System made these statements over fifty years ago-before the patent term was adjusted to twenty years from the date of filing and prior to the creation of the Federal Circuit-it appears that much of what the Economic Review of the Patent System described in 1958 remains true today in the context of biologics.

148. See Grabowski 2008, supra note 5, at 4 ("[T]here is a much higher probability now than there was a decade ago that drugs will experience patent challenges and that they will occur much sooner after brand launch."); Grabowski 2009, supra note 5, at 2 ("Patents may provide less clear and less predictable intellectual property protection for biologics than for small molecule drugs."').

149. See infra Part III.C.1.b.; see also BIO DATa Exclusivity Position Paper, supra note 5, at 2-3 (arguing that patent law yields increasingly narrow patent claims to biologics).

150. See Laura A. Coruzzi, Jonathan A. Muenkel \& Lynda Q. Nguyen, The Crusade for Follow-On Biologics: The Next Wave of Pharmaceutical Patent Litigation?, 2 LANDSLIDE 30, 
and elaborate framework for the resolution of patent disputes arising out of the filing of an application for biosimilar products. ${ }^{151}$ This framework requires potential adversaries to obtain extensive legal counseling ${ }^{152}$ and, possibly, litigate numerous patent disputes in several different legal proceedings over a prolonged period of time. ${ }^{153}$ Furthermore, protecting a single biological product normally involves more than one patent, so it is prudent to assume that patent disputes arising in the context of biologics would not only entail several legal proceedings over a prolonged period of time, but would also involve several patents directed to different types of inventions. ${ }^{154}$

Finally, the scope afforded to patents pertaining to biologics by courts is even more unpredictable than that of patents generally because of the uncertainty surrounding the application of the doctrine of equivalents to this relatively new area of technology. ${ }^{155}$ Combining all of the above with the

31 (2009) (predicting that the passage of a framework for the approval of generic versions for biological products may "result in an influx of patent litigation in the field of biology").

151. See supra notes 93-104 and accompanying text.

152. BPCIA dictates that the parties involved in the patent dispute partake in an exchange of patent lists and statements of their respective legal positions, to be followed by negotiations aimed at the resolution of possible patent disputes prior to and in lieu of resorting to any legal action in court. See BPCIA $\$ 7002(a)(2)$ (codified at 42 U.S.C.A. $\$ 262(k)$ (West 2012)). Given these proceedings' robustness, the necessary involvement of attorneys is likely to come at a substantial cost.

153. The framework set up in BPCIA accounts for the possibility that patent disputes under BPCIA may involve several different legal proceedings spanning over the course of eight years or more, beginning with the expiration of the data exclusivity period - four years after the approval of the original product-and ending with the conclusion of actions for declaratory judgment or injunction prompted by an advance notice of intent to market a biosimilar product given 180 days prior to the onset of marketing. See id. (codified at 42 U.S.C.A. $\$ \S 262(\mathrm{k})(6)-(9)$ (West 2012)). The existence of patents covering biological products would automatically trigger the BPCIA patent dispute resolution proceedings even if the patents are set to expire prior to the end of the market exclusivity period.

154. See Grabowski 2009, supra note 5, at 2-3 ("Biologics rely on multiple patents, including narrower product patents and process patents."); see also supra notes 112-115 and accompanying text. More patents represent a larger investment in prosecution and enforcement as well as increased uncertainty regarding the scope of the protected rights and the degree and extent of their enforceability.

155. The doctrine of equivalents is a patent law construct meant to encompass within the scope of patent claims subject matter which does not squarely fall under the literal meaning of the claim but is nonetheless equivalent to the patented invention. The most common legal standard for equivalence is the "function-way-result" test according to which a product or process is deemed an equivalent where "the accused product or process performs substantially the same function, in substantially the same way, to achieve substantially the same result, as disclosed in the claim." See Abbott Labs. \& Astellas Pharma, Inc. v. Sandoz, Inc., 566 F.3d 1282, 1296-97 (Fed. Cir. 2009) ("Equivalency may also be proven where the differences between the invention as claimed and the accused product or process are insubstantial."). Thus, for example, even if a generic biological API would not literally infringe the relevant compound claim, it could trigger an issue of equivalents if the two compounds would have substantially the same structure enabling them to achieve substantially the same result in substantially the same way or are otherwise only different in an insubstantial way. According to the Biotechnology Industry Organization (BIO), "[b]iotechnology is considered an unpredictable field because it is often not known how even a minor change may affect the structure, behavior 
already increased likelihood of patent challenges in the pharmaceutical sector in recent years, ${ }^{156}$ the prospect of utilizing patents to protect proprietary interests of developers of biological products appears to be far from attractive. This may, in turn, result in a curbing of $R \& D$ investment. ${ }^{157}$

Interestingly, these shortcomings of the patent system are "complemented" with claims that, at least in the context of biologics, patents do not serve their role as facilitators of disclosure of valuable information to the public. ${ }^{158}$ Biotechnology patents have been accused of not providing sufficient disclosure to benefit the public and of revealing only piecemeal portions of certain technologies, which are useless in and of themselves and which could only serve as part of larger mechanisms to which the public is not made privy. ${ }^{159}$

and biological activity of a protein." BIO WHITE PAPER, supra note 2, at 28 . Thus, if even a seemingly minor change to a biological compound may drastically affect its structure, the way it functions, or its biological result, then it is possible to say that such minor changes in a biological compound would affect the "function-way-result" aspects of such compound in a "not insubstantial way," which in turn would render the scope of equivalents in such a compound highly unpredictable. Accordingly, as recognized in the BIO White Paper, "there is no certainty that an innovator can obtain adequate patent protection covering variant proteins." BIO White PAPER, supra note 2, at 28; see also Natasha L. Aljalian, The Role of Patent Scope in Biopharmaceutical Patents, 11 B.U. J. SCl. \& TECH. L. 1, 55-57, 66-72 (2005) (arguing that "[t]he application of the doctrine of equivalents in the realm of gene and protein patents, which appear to be the foundation of new medical breakthroughs, is highly significant .... [t]hus there is debate over its applicability" and there are calls for limiting the applicability of the doctrine of equivalents in such patents). Notably, one way to address this difficulty that is often used in claims directed to biological subject matter is to claim compositions that are "at least XX\% identical" to the sequence recited by the claim. This, of course, could give rise to similar difficulties to the ones encountered under the doctrine of equivalents, only this time in the context of claim construction.

156. See Grabowski \& DiMasi 2009, supra note 5, at 19 ("[T]he trend in recent years has been for patent challenges to become much more frequent.").

157. See 2008 CRS REPORT, supra note 1, at 26 ("[S]everal experts maintain that defending patents may divert support from on-going innovation, especially in small companies that make up a significant portion of the biotechnology sector.").

158. See supra Part I.A.1.

159. See, e.g., Sorscher, supra note 58, at 304 ("[T] The patent for [biologics] may only cover early versions of the product produced in the laboratory setting, not the master cell lines and scaled-up industrial process used to produce the product eventually tested on patients and approved by the FDA. Firms can and do seek trade secret protection on these cell lines and processes, forcing follow-on manufacturers to start over after a long and expensive design process.").

Arguably, the statutory exclusivities established under BPCIA do not do a better job of facilitating disclosure of meaningful or practical information to the public since the actual clinical data and manufacturing know-how submitted as part of the original BLA is considered proprietary and therefore not accessible to the public. See generally Dinh, supra note 3, at 102-103 (arguing that drug developers have no property interest in the public fact that a certain drug was found to be safe and efficacious enough to be approved for marketing and because such reliance does not involve an actual disclosure of clinical data submitted by drug developers); John C. Yoo, Takings Issues in the Approval of Generic Biologics, 60 FOOD \& Drug L.J. 33, 43 (2005) ("If FDA decided to use the knowledge acquired by a pioneer company in furtherance of a subsequent approval of a generic biologic drug, the agency likely 
FDA-granted statutory exclusivities, on the other hand, are obtained and enforced automatically as a by-product of the FDA approval proceedings, ${ }^{160}$ and their practice does not require their beneficiary to take any specific action. ${ }^{161}$ They also do not lend themselves to the skirmishes that characterize patent infringement disputes. ${ }^{162}$ Thus, statutory exclusivities negate the need for long, cumbersome, expensive, and uncertain proceedings such as those characterizing patent prosecution and enforcement, which makes statutory exclusivities highly appealing as the means of protecting one's investment in technology. ${ }^{163}$ Statutory exclusivities provide a relatively predictable

would encounter no significant taking issue."); Andrew Wasson, Note, Taking Biologics for Granted? Takings, Trade Secrets, and Off-Patent Biological Products, 2005 DUKE L. \& TECH. REv., 0004, \30, available at http://www.law.duke.edu/journals/dltr/articles/2005dltr 0004.html (arguing that "it is unlikely that the approval of off-patent biologics originally approved under the [F]FDCA would be a taking"); Letter from Prof. John C. Yoo, Univ. of Cal., Berkeley, Sch. of Law, to the Food \& Drug Admin., Div. of Dockets Mgmt. (Oct. 21, 2004), available at http:/www.gphaonline.com/sites/default/files/UC-Berkeley\%20Professor\%20 Yoo's\%20Analysis\%20of\%20the\%20Takings\%20Clause.pdf (addressing the constitutionality of the FDA's reliance on safety and efficacy conclusions reached in approval proceedings of original biological products for the approval of generic versions of such products and determining that it is not a taking of such (admittedly) proprietary information under the Fifth Amendment). Some commentators have argued that the FDA should make full disclosure to the public of safety and efficacy data relied on as part of approval proceedings of new pharmaceuticals. See e.g., Christine D. Galbraith, Dying to Know: A Demand for Genuine Public Access to Clinical Trial Results Data, 78 Miss. L.J. 705, 712, 752-54, 762-67 (2009) (making a compelling argument in favor of "comprehensive disclosure of meaningful clinical trial data from all studies, regardless of whether FDA approval is obtained or even sought").

160. As discussed earlier, statutory exclusivities are conferred "automatically" on recipients of FDA marketing approvals and thus, securing them requires no direct additional investment on the part of developers of biologics. Putting a biologic through all the tests and clinical trials necessary for approval by the FDA is an essential and unavoidable part of its approval for marketing. Therefore, the investment involved in obtaining FDA approval for biological products should be viewed as sunk costs, i.e., as a necessary expenditure that has to be invested regardless of the legal protection sought for the investment. Hence, the direct investment in obtaining a statutory exclusivity could be viewed as zero while obtaining and securing patents in related inventions would presumably involve additional costs. Similarly, the enforcement of patents would require the developers of original biologics to invest significantly in bringing lawsuits against infringers. As for statutory exclusivities, it is the FDA that bears the costs of litigating possible challenges of its decisions not to approve additional products and not the developers of the original products.

161. Under BPCIA, potential competitors are barred from even attempting to enter the market while the statutory exclusivities are in place because the FDA is unable to accept for evaluation any application for a follow-on biological product prior to the expiration of the data exclusivity period or approve such applications prior to the expiration of the market exclusivity period. See supra notes $84-85$ and accompanying text.

162. As discussed earlier, statutory exclusivities are significantly less vulnerable to legal challenges than patents. See supra Part I.B; see also BRILL, supra note 5, at 6 ("Patents can, and frequently are, subject to legal challenge and therefore contain some amount of uncertainty for the patent holder. Data exclusivity is not challengeable in court and therefore is not uncertain.").

163. See BRILL, supra note 5, at 6. The application of statutory exclusivities is not affected by the inherent uncertainty accompanying patent law, especially with regard to such matters as the application of the doctrine of equivalents, meeting of burdens of proof, "battles of experts," inequitable conduct, and more. 
outcome in case of potential disputes, which, in turn, represents not only significant cost savings but also minimization of investors' risks, thereby creating a business environment favorable to investment in R\&D. ${ }^{164}$

\section{b. The 'Product of Nature' Doctrine and the Insufficiency of Patents as Means of Promoting Basic Research and Development in Biology and Biomedicine}

There are various types of bioiogics for which patentability is limited and yet for which R\&D is highly desirable from a public policy perspective. ${ }^{165}$ In many of these instances, the impediment to patentability is the 'product of nature' doctrine according to which patents may only be granted for "nonnaturally occurring [articles of] manufacture or composition[s] of matter" that are "product[s] of human ingenuity." 166 In other cases, the obstacles may be the heightened standards of written description and enablement, ${ }^{167}$ utility, ${ }^{168}$ and other issues specific to the field of bio-

164. In this respect, the legal certainty accompanying a regime of statutory exclusivities has a clear advantage over patents from an incentive-to-invent/invest public policy perspective.

165. For example, genes, naturally occurring nucleic acid sequences (DNA and RNA) that have not been fully sequenced, non-purified naturally occurring compositions containing antibodies, naturally occurring proteins and hormones, and so forth. See Kelleher, supra note 57 , at 256 ("[T]he patentability of some biological materials is extremely narrow due to stringent specification and enablement requirements.").

166. See Diamond v. Chakrabarty, 447 U.S. 303, 309-10 (1980). According to the Chakrabarty Court, "[t]he laws of nature [and] physical phenomena ... have been held not patentable.... Thus, a new mineral discovered in the earth or a new plant found in the wild is not patentable subject matter. . . Such discoveries are 'manifestations of . . nature, free to all men and reserved exclusively to none.' $I d$. at 309 (citations omitted). The 'product of nature' doctrine bears particular relevance to the context of biologics because so many biological products are in fact naturally occurring molecules, e.g., human growth hormone, insulin, and erythropoietin. See 2008 CRS REPORT, supra note 1, at 13 (addressing the implications of the 'product of nature' doctrine on biologics).

167. See, e.g., Fiers v. Revel, 984 F.2d 1164,1170 (Fed. Cir. 1993) ("An adequate written description of a DNA requires more than a mere statement that it is part of the invention and reference to a potential method for isolating it; what is required is a description of the DNA itself."); In re Argoudelis, 434 F.2d 1390, 1392 (C.C.P.A. 1970) (requiring making a deposit of microorganisms to a publicly available depository as part of meeting the written description and enablement requirements under 35 U.S.C. $\$ 112$, first paragraph); BIO WHITE PAPER, supra note 2, at 30-32 (arguing that biotechnology is subject to "strict written description and enablement" requirements); Aljalian, supra note 155, at 28-30 (arguing that "biotechnology has come to have greater written description and enablement requirements, and patents in this field have been required to strictly comply with these requirements"); Tam, supra note 46 , at $544-47$ (reviewing issues pertaining to enablement of biological inventions and arguing that many patents pertaining to biologics may be invalid for lack of enablement). See generally Karen G. Potter, Getting Written Description Right in the Biotechnology Arts: A Realist Approach to Patent Scope, 28 Biotechnology L. ReP. 1, 17 (2009) (describing the uncertainty surrounding the law of written description in biotechnological patents).

168. See John R. Thomas, Cong. Research Serv., RL30648, An Examination of the Issues Surrounding Biotechnology Patenting and Its Effect Upon EntrepreNEURIAL COMPANIES, at 18-26 (2000) [hereinafter 2000 CRS REPORT] (addressing the application of the utility requirement under 35 U.S.C. $\$ 101$ to biotechnologies). 
technology. ${ }^{169}$ As a result, there is ongoing concern that such impediments to patentability might hinder highly desirable $R \& D$ of some types of biologics by making them insufficiently attractive to potential investors. ${ }^{170}$

Various solutions have been proposed over the years to ease the tension between the need to encourage "basic research" (i.e., research that is aimed at the discovery and understanding of natural phenomena) and patentability. ${ }^{171}$ However, these solutions have usually been partial at best and, thus far, have failed to bring a conclusion to the debate over the patentability of specific types of biologics. ${ }^{172}$

Contrary to the seemingly arbitrary and stringent requirements for obtaining a patent in the context of biologics, the statutory exclusivities regime set up by BPCIA does not give rise to similar impediments. Rather, it facilitates granting statutory exclusivities independent of external criteria such as "patentability" and depends only on the FDA's finding of biological products as sufficiently safe and effective. ${ }^{173}$ Thus, the statutory exclusivities regime established by BPCIA incentivizes any kind of R\&D project that may eventually lead to biological products regardless of its patentability, including

169. See, e.g., Amgen, Inc. v. Chugai Pharm. Co., 927 F.2d 1200, 1206 (Fed. Cir. 1991) ("[W] hen an inventor is unable to envision the detailed constitution of a gene so as to distinguish it from other materials, as well as a method for obtaining it, conception has not been achieved until reduction to practice has occurred, i.e., until after the gene has been isolated."). See also 2000 CRS REPORT, supra note 168, at 11-18 (addressing potential obstacles to patentability due to what the author describes as "ethical concerns"); Ass'n for Molecular Pathology v. U.S. Patent \& Trademark Office, 653 F.3d 1329 (Fed. Cir. 2011), reh'g denied (Sept. 13, 2011), reh'g denied (Sept. 16, 2011) cert. granted, judgment vacated, matter remanded, 11-725, 2012 WL 986819 (U.S. Mar. 26, 2012) (holding that composition of isolated DNA sequences associated with cancer were patent-eligible subject matter but that methods for comparing or analyzing isolated DNA sequences associated with predisposition to cancer were not patentable).

170. One such type of research involves the identification of particular genes and naturally occurring mutations in the human genome. Among the most prominent types of genetic diseases whose exact genetic background remains unknown at this time are asthma, various types of cancer, and epilepsy. See Cancer Genetics Overview, NAT'L CANCER INST., http:/www.cancer.gov/ cancertopics/pdq/genetics/overview/HealthProfessional/page2 (last visited Feb. 8, 2012) ("[the] expanding knowledge [of cancer genetics] has implications for all aspects of cancer management, including prevention, screening, and treatment"); NINDS Epilepsy Information Page, NAT'L INST. OF Neurological Disorders \& STrokes, http://www.ninds.nih.gov/ disorders/epilepsy/epilepsy.htm (last visited Feb. 8, 2012) ("Researchers are working to identify genes that may influence epilepsy."); What Causes Asthma?, NIH HEART, LUNG \& BLoOD INST. (Feb. 1, 2011), http://www.nhlbi.nih.gov/health/health-topics/topics/asthma/causes.html ("Researchers think some genetic and environmental factors interact to cause asthma.").

171. For example, courts have created an exception for naturally occurring compounds if such compounds are "purified and isolated." See supra note 112.

172. A recent example of an ongoing ambiguity of the patentability of biologics is the continuing debate regarding the patentability of naturally occurring DNA sequences (e.g., genes) and variations thereof (e.g., cDNA or diagnostic products thereof). See Ass'n for Molecular Pathology, supra note 169.

173. See discussion infra Part III.C.I.a. 
research that may lead to the discovery of naturally occurring or nonisolated biological compounds. ${ }^{174}$

\section{c. Patents Provide Insufficient Protection to Biological APIs and the Processes of Making Them}

In some situations, patent compound claims ${ }^{175}$ and claims directed to methods of making them might prove ineffective in protecting particular biological compounds. ${ }^{176}$ As explained earlier, biological compounds are highly complex molecules and are often made of hundreds, sometimes thousands, of building blocks arranged in intricate three-dimensional structures. ${ }^{177}$ Thus, biological compounds and the processes of making them normally lend themselves to an enormous number of potential variations, which could be used for "designing-around" patent claim limitations in order to yield highly similar compounds or highly similar processes of making them. ${ }^{178}$

174. A notable exception to the broad applicability of statutory exclusivities and their potential as means of incentivizing $R \& D$ in biomedical technology exists in relation to the development of means of diagnosing certain diseases, including by using identified DNA and RNA sequences. For the reasons mentioned above, newly identified genes are currently held unpatentable. See supra note 172 and accompanying text. However, they also seem to not fall under the definition of biologics under PHSA $\$ 351(i)$. See supra note 2 and accompanying text. Nonetheless, genetic diagnostics have an important role in the prevention and treatment of certain diseases and genetic predispositions that could not have otherwise been detected. For example, the tests for the presence of mutations in the BRCA1 and BRCA2 genes associated with increased risk of developing breast and ovarian cancers, while not serving as means of preventing such cancers per se, assist in recognizing the need for medical surveillance and preventive treatment for individuals having these mutations. See BRCAl and BRCA2: Cancer Risk and Genetic Testing, NAT'L CANCER INST., http://www.cancer.gov/cancertopics/factsheet/ Risk/BRCA (last visited Feb. 8, 2012). Thus, it is desirable to grant some form of statutory exclusivities-even if shorter than those afforded by BPCIA-in genetic diagnostics so as to incentivize research leading to the development of such diagnostics. See Gregory Dolin, Exclusivity Without Patents: The New Frontier of FDA Regulation for Genetic Materials, 98 IOWA L. REv. (forthcoming 2012), available at http://papers.ssrn.com/sol3/papers.cfm? abstract_id=20201 12.

175. Compound claims are patent claims drafted specifically to cover a particular chemical or biological compound or a group of particular compounds defined by structure, function, or characteristics (e.g., melting point, X-ray diffraction pattern, solubility, density).

176. See Grabowski et al., supra note 5, at 4 ("Patent protection alone may be insufficient for biologics in the context of biosimilars."); Kelleher, supra note 57, at 256 ("The complexity of most biologics may allow a biogeneric manufacturer to design around an innovator's patents, but still secure regulatory approval through its 'biosimilarity' to the pioneer biologic.").

177. See supra note 2 .

178. See BIO DAta Exclusivity POSITION PAPER, supra note 5, at 1 (discussing why biologics are susceptible to "design-arounds" and negative consequences thereof); JIM Hollingshead \& Rob Jacoby, Avolding No Man's Land: Potential Unintended CONSEQUENCES OF FOLLOW-ON BIOLOGICS 16 (2009), available at http://www.deloitte.com/ assets/Dcom-UnitedStates/Local\%20Assets/Documents/us_lshc_avoiding\%20no\%20man's\%20lan d_FOB_033009(1).pdf ("[M]any industry participants are concerned that innovators' patents will prove relatively easy to circumvent. The very size of these molecules opens the possibility that a very small change to the molecule that preserves the core design ... could circumvent 
Moreover, for the reasons discussed earlier, the doctrine of equivalents might not provide effective means for encompassing "design-arounds" within the scope of the relevant claims. ${ }^{179}$ Given the innumerable possibilities of "design-arounds" that exist for many biological compounds and the general unpredictability of the results of even minor changes to biological compounds, the application of the doctrine of equivalents to biotechnological inventions might prove extremely difficult. ${ }^{180}$ Even if we assume that the changes to the biological compound do not substantially affect the way it achieves a "substantially same" result, there would still remain the difficult question: what is "substantial structural similarity" in biologics for equivalence purposes? Apparently, the likelihood of establishing infringement of a biological compound claim under the doctrine of equivalents (at least at this point in time) is low at best, which under some circumstances may make it easy for generic manufacturers to enter the market with their "biosimilar" versions of approved biological compounds before developers of

the IP of the innovator company without technically infringing on its patent. Similarly, it is theoretically possible that [a generic manufacturer] could create a nearly identical molecule through a different process, and again be deemed technically to not be in violation of patents."); Gitter, supra note 2, at 612 (explaining that generic versions of biologics "might be sufficiently similar to the innovator biologic to rely on the FDA's findings of safety and effectiveness for the innovator product, but at the same time prove different enough from the innovator product to avoid a patent infringement claim").

179. In view of the size of some proteins, it is quite possible that generic manufacturers could develop proteins that would be substantially structurally different from the original biological compound and yet have biological activity identical or highly similar to that of the original compound and therefore fall under the definition of "biosimilar" under BPCIA. See supra note 155 and accompanying text; see also Grabowski 2009, supra note 5, at 2-3 ("Biologics rely on multiple patents, including narrower product patents and process patents that may be more vulnerable to inventing around than small molecule product patents. . . [I]t is possible that biosimilars may be different enough not to infringe on patents, but similar enough to qualify for an abbreviated approval pathway."); Potter, supra note 167, at 14-15 ("In practice, the Courts are reluctant to apply [the doctrine of equivalents] in bintechnology cases .... It is far from certain how much variation in a protein a court would deem to be an "insubstantial" change. In sum, the [doctrine of equivalents] is so restrictive as to "eviscerate the applicability and potency of the [doctrine of equivalents] in almost all imaginable situations."').

180. See BIO WHITE PAPER, supra note 2, at 30 (explaining that two structurally different proteins could be biologically equivalent and still there would be no patent infringement); Marr, supra note 57, at D1 ("Because biosimilars aren't exact duplicates of the original drugs, they don't violate the original drug's patent, enabling legal distribution before patent expiration."); Vernon et al., supra note 5, at 69 (arguing that it would be easy to "design around" biological products and that "[t]his artifact of intellectual property rights law places a greater emphasis on [statutory] exclusivity provisions for biologic products"). But see FTC REPORT, supra note 5 , at vi ("There is no evidence that patents claiming the compound or molecule of pioneer biologic drugs have been designed around more frequently than those claiming smallmolecule drug products."); Potter, supra note 167, at 1, 14-15 (describing a hypothetical case in which strict written description requirements make a patentee narrowly claim its invention thereby "inviting" imitations that do not fall within the scope of the invention as claimed). 
original biologics had a chance to reap the profits that would make their efforts worthwhile. ${ }^{181}$

The statutory exclusivities framework established under BPCIA does not give rise to such potential uncertainties and eliminates the need to litigate altogether. The BPCIA statutory exclusivities framework institutes a clear choice: if one wishes to rely on a previous FDA approval of a certain biological product without having to invest the vast amounts of money necessary in order to obtain independent approval of one's own product, one must wait until the expiration of the relevant statutory exclusivity periods. ${ }^{182}$ Under a statutory exclusivities regime, a generic manufacturer need only seek to obtain approval for its product to trigger the statutory exclusivity bar forbidding the FDA to approve the application regardless of whether or not the biological compounds are similar enough to be used interchangeably and the degree of their similarity.

\section{d. Patents Provide Poor Protection to Biologics Manufacturing Know-How}

For many biologics, one of the most difficult and important aspects of bringing the product to the market is the development of manufacturing know-how. ${ }^{183}$ However, for various reasons, know-how is especially difficult to protect under patent law. First, viewed through a patent-law prism, the majority of manufacturing techniques are "well known in the art." 184 Thus, the manufacturing recipes of most biological products could, arguably, be developed through 'routine experimentation' and would therefore be obvious under 35 U.S.C. $\$ 103 .{ }^{185}$ Second, as explained earlier, patent claims

181. Cf. Amgen v. Hoechst, 126 F. Supp. 2d 69, 132-35 (D. Mass. 2001), rev'd 457 F.3d 1293, 1308-12 (Fed. Cir. 2006) (finding that a patent claim for a 164 amino-acid erythropoietin was infringed under the doctrine of equivalents where the allegedly infringing molecule had only one more amino acid on the $\mathrm{C}$ terminus and achieved substantially the same clinical result in the same way and holding that there was no prosecution history estoppel).

182. Notably, the possibility of approval of two parallel, potentially identical APIs for treatment of the same medical condition raises the separate issue of inefficiencies involved in parallel development of pharmaceutical products. A possible way of avoiding the waste of resources associated with such situations-at least those resulting from the respective developers' unawareness of the competing project $\longrightarrow$ would be to have the FDA publish preliminary details regarding INDs it receives.

183. See BIO WHITE PAPER, supra note 2, at 3 (explaining some of the difficulties involved in the manufacturing of biological compounds and their susceptibility to changes in manufacturing processes).

184. In other words, "well known" to persons of ordinary skill in the pertinent forms of art, such as molecular biology or biochemistry.

185. See Ritchie v. Vast Resources, Inc., 563 F.3d 1334, 1337 (Fed. Cir. 2009) ("Among the inventions that the law deems obvious are those modest, routine, everyday, incremental improvements of an existing product or process that confer commercial value . . but do not involve sufficient inventiveness to merit patent protection. This class of inventions is well illustrated by efforts at routine experimentation [where] ... method[s] of creation are well known, making successful results of the experimentation predictable."). 
covering manufacturing processes could, and often are, "designed-around," namely, evaded by making the same products in a different way, thereby rendering them irrelevant to protecting the substantial investment involved in the development of manufacturing know-how. ${ }^{186}$

A grant of statutory exclusivities under BPCIA, on the other hand, does not require disclosure of manufacturing know-how to third parties (e.g., generic manufacturers). ${ }^{187}$ Similarly, third parties are not able to circumvent statutory exclusivities under BPCIA by "designing around" the protected products (at least not if the applicant wishes to rely on the original product for approval of its own generic version thereof). ${ }^{188}$

\section{Why Concurrent Patent and Statutory Exclusivities Protection in Biological Products Might Have Undesirable Ramifications}

In view of the above, it is not surprising that developers of biological products advocated vehemently in favor of long statutory exclusivity periods for original biological products. ${ }^{189}$ However, even though the literature is replete with arguments in favor of making statutory exclusivities available to biological product developers in addition to patents, ${ }^{190} \mathrm{I}$ am not aware of similar arguments having been made regarding a supposed need for patent protection in addition to and concurrent with the term of statutory exclusivities such as those provided under BPCIA; nor am I aware of any justification for affording such protection. ${ }^{191}$ In other words, no one seems to argue that statutory exclusivities, while they last, provide insufficient protection to the interests of developers of biological products such that they should be supplemented by patent protection. Rather, it appears that affording protection under both patent and statutory exclusivities regimes while both of them are in effect is likely to have undesirable ramifications.

186. See Grabowski 2009, supra note 5, at 2-3; supra text accompanying note 181; see also BIO WHITE PAPER, supra note 2, at 32 ("It is rare that a patented process of chemical synthesis will be able to block any and all means of producing the product.").

187. See supra note 159 , 112.

188. See supra note 182 and accompanying text.

189. See, e.g., Grabowski 2009, supra note 5, at 3 (listing the advantages of statutory exclusivities and how they remedy the shortcomings of patents in the context of biologics).

Arguably, the most straightforward way of addressing the inadequacy of the patent system for protecting biotechnological inventions would be to "fix" the patent system itself, namely by tailoring specific solutions that would encompass the type of product of biotechnological research and development activities that policy makers seek to incentivize within the scope of what patent law would deem patentable subject matter. However, this route would not be preferable to statutory exclusivities because such highly specific biotechnologyoriented solutions might even further increase the transaction costs involved in obtaining and enforcing biotechnology patents.

190. See, e.g., supra text accompanying note 5.

191. As explained earlier, statutory exclusivities negate the need for patent protection at least for the underlying compounds comprising biological products, the methods of making them, and the initially approved methods of using them. 


\section{a. Concurrent Protection by Both Patents and Statutory Exclusivities Leads to a Waste of Societal Resources}

The enforcement of patents is an expensive prospect not only for the individual parties involved but also for society at large. Patent systems require substantial investment in education and training necessary to administer patent prosecution and litigation. ${ }^{192}$ Moreover, maintaining a patent system with all its numerous elements, including a patent office, the various tribunals partaking in the administration and enforcement of patent law, ${ }^{193}$ and highly trained personnel, ${ }^{194}$ requires a significant ongoing investment of societal resources. ${ }^{195}$ Thus, the investment of resources in the enforcement of patent rights where statutory exclusivities already cover biological products constitutes a waste of the relative portion of societal resources that is necessary to facilitate such enforcement. ${ }^{196}$

\section{b. Concurrent Protection by Both Patents and Statutory Exclusivities Gives Rise to Unnecessary and Avoidable Risks of Abuse}

Monopoly creates an inherent risk of abuse. ${ }^{197}$ Thus, affording patent protection for biological products in parallel to FDA-instituted exclusivities increases the risk of abuse by developers of biological products in a variety of ways and disserves the public interest that both regimes were created to promote. ${ }^{198}$ Such abuse might result in an anti-competitive impact on incen-

192. Hypothetically, had these resources not been invested in this manner, they could have been invested in other equally or possibly more socially beneficial avenues.

193. For example, the Patent Trial and Appeals Board (PTAB; formerly known as the Board of Patent Appeals and Interferences), International Trade Commission, and federal courts.

194. For example, judges, administrative law judges, patent examiners, and all their professional and administrative staff.

195. Notably, the administration of the patent dispute resolution scheme established in BPCIA requires even further investment of societal resources such as those described herein. See further discussion of the BPCIA patent dispute resolution scheme supra Part III.C.1.a.

196. To clarify, the argument here is not that the entire societal investment of resources in the creation and maintenance of a patent system constitutes waste, but rather that the relative portion of such an investment which is necessary to support the handling of patent disputes as they pertain to biological products which are being covered by statutory exclusivities under BPCIA is wasteful.

197. The Economic Review of Patent System defines "abuse" as a situation where "the social objectives which [the monopoly] is supposed to serve are not promoted but rather jeopardized by the way it is used[,]. . . . when the temporal, functional, or material limits of the monopoly intended by the [monopoly] grant are overstepped and the actually achieved monopolistic control is extended in time, in scope or in strength." See Economic Review of PATENT SYSTEM, supra note 11 , at 10.

198. For example, numerous commentators have expressed concerns regarding patent abuse practices commonly referred to as "evergreening." See, e.g., Laurence J. Kotlikoff, Clearing the Way to Low-Cost Biogenerics, Boston Globe (Oct. 26, 2008), http://www.boston.com/bostonglobe/editorial_opinion/oped/articles/2008/10/26/clearing_the_ way_for_low_cost_biogenerics (warning against granting developers of original biologics 
tives to invest in biologics' R\&D, which would, almost inevitably, diminish public access to biological products. ${ }^{199}$

BPCIA accounts for the risk of abuse of statutory exclusivities by specifically and explicitly disallowing grants of market and data exclusivities under certain circumstances. First, BPCIA stipulates that applications for the approval of biologics that are "supplements" to an original BLA cannot re-trigger the market and data exclusivity provisions. ${ }^{200}$ Second, BPCIA determines that applications filed by the same manufacturer or its "licensor, predecessor in interest, or other related entity" do not merit data or market exclusivity if the application is merely for a "modification to the structure of the biological product that does not result in a change in safety, purity, or potency."201 Finally, under BPCIA, an application filed by the same manufacturer for a non-structural change of the biologic and "that results in a new indication, route of administration, dosing schedule, dosage form, delivery system, delivery device, or strength" does not award the manufacturer with an exclusivity period on top of that already awarded for the original biological product. ${ }^{202}$

twelve to fourteen years of statutory exclusivity alongside with patent protection and arguing that such protection would increase the risk that developers of original biologics would attempt to evergreen their biological products). According to Kotlikoff, evergreening is "mak[ing] relatively minor changes to existing products in order to restart their monopoly protection clocks. These changes include changing the medication strength of pills[,] ... changing the form of medication (e.g., switching from pill to capsule), modifying the method of delivery (e.g., from injection to inhalation), expanding indications (applying the medicine to additional conditions), pegylation (which has the effect of reducing doses per time period via time-release mechanisms), and glycosolation [sic] (adding sugar molecules to the medication)." KotlikofF, supra note 5, at 9. See also BRILL, supra note 5, at 7 ("[e]vergreening is a process whereby the holder of the patents for a biologic drug, using incremental changes to its original product, is able to shift the market to a newer product so as to limit a generic competitor's market opportunity").

199. See ECONOMiC Review of PATENT System, supra note 11, at 10-11 ("Patentees may succeed in extending the time period of control [e.g.]. . through incomplete disclosure, making it impossible for those without special 'know-how' to use the invention even after expiration of the patent; ... through the successive patenting of strategic improvements of the invention which make the unimproved invention commercially unusable after expiration of the original patent .... The patentee may succeed in extending the scope and strength of the monopoly beyond that intended by the law."); id. at 28 (reviewing different arguments made by others that patents have been misused in various ways to inhibit fair and free competition regardless of efficiency); id. at 31 (quoting Edwards's statement that "[there] are cases in which one enterprise has held control through patents [of an industry] for periods as long as half a century").

200. See BPCIA $\$ 7002$ (a) (codified at 42 U.S.C.A. $\$ \$ 262(\mathrm{k})(7)(\mathrm{C})(\mathrm{i})$ (West 2012)). 201. See BPCIA $\$ 7002$ (a) (codified at 42 U.S.C.A. $\$ \$ 262(k)(7)(C)$ (ii)(I) (West 2012)). 202. See BPCIA $\$ 7002$ (a) (codified at 42 U.S.C.A. $\$ 262(k)(7)(C)(i i)(I I)$ (West 2012)). These provisions leave open the possibility of granting new data or market exclusivity terms for approval of applications for biological products submitted by the same manufacturer that entail a structural change to an original biological product and that result in a new indication, route of administration, dosing schedule, dosage form, delivery system, delivery device, or strength. Yet, arguably, such re-triggering of the exclusivity period is justifiable since the manufacturer would have to put the biological product through what essentially would be a new 
Patent law, on the other hand, does not seem to have the same kind of safeguards against abuse. Thus, patents remain relatively susceptible to evergreening. ${ }^{203}$ Furthermore, the elaborate patent dispute resolution scheme established in BPCIA might also, conceivably, give rise to different types of abuse similar to those that have been affected under the Hatch-Waxman Act. ${ }^{204}$ Thus, protecting biological products under patent law in addition to the statutory exclusivities framework available under BPCIA creates an opening for abuses of the patent system that may delay the entry of generic biologics into the market.

\section{Biological Products Should Not Receive Concurrent Protection Under Both Patent Law and the Statutory Exclusivities Afforded Under BPCIA}

The conclusion from the discussion thus far is that concurrent protection of biologics under both patent and statutory exclusivities regimes is not only unnecessary but also undesirable. Rather, it would be preferable that any particular biological product be subject to protection under only either of these regimes at any given time, namely BPCIA instituted statutory exclusivities or patents covering the underlying inventions pertaining to the biological product.

approval process, including full blown clinical trials, and would therefore need to "re-invest" in R\&D of what may well be viewed as a new and different biological product. Notably, the BPCIA anti-evergreening provisions are in accord with Professor Kotlikoff's recommendations for such measures. See KotlikofF, supra note 5, at 9 (proposing to award full monopoly protection only for the discovery and marketing of a new biologic)

By not affording additional statutory exclusivity for approval of additional indications of the same biological product, the statutory exclusivity scheme created by BPCIA differs from that of the Hatch-Waxman Act in that BPCIA does not incentivize additional clinical research leading to the approval of the same biologic for the treatment of additional medical conditions. See discussion of the Hatch-Waxman Act supra note 29 and accompanying text. In providing such exacting criteria for the grant of statutory exclusivities for already-approved drugs, BPCIA might actually curb much needed follow-up research of already-approved biological products, especially with relation to indications that require more complicated or elaborate R\&D efforts which, as such, tend to be "pushed back" for later approval.

203. See Galbraith, supra note 159, at 759 (2009) ("[P]harmaceutical companies have recently employed a wide variety of 'evergreening' strategies to artificially extend the date a medication officially goes off patent."). A comprehensive review of the numerous possible "methods" of patent abuse and "evergreening techniques" in the context of biologics is beyond the scope of this Article.

204. See, e.g., Fed. Trade Comm'n, Generic Drug Entry Prior to Patent ExpiraTION: AN FTC STUDY (2002), available at http:/www.ftc.gov/os/2002/07/genericdngstudy.pdf (describing several types of patent abuse "techniques" used to keep generic competition off the market); see also FTC REPORT, supra note 5, at viii ("[E]arly start [of pre-approval litigation] does not guarantee early resolution. ... [B]ased on the experience under Hatch-Waxman, a pre-approval patent resolution process also is likely to lead to consumer harm ... [by using] the pre-approval patent regulations to delay generic entry. In addition, generic and branded competitors have entered into 'pay-for-delay' patent settlements that delay entry, not encourage it."). Arguably, similar abuses could occur under the pretext of patent dispute resolution under BPCIA. 
As explained earlier, statutory exclusivities have numerous advantages over patents. ${ }^{205}$ At least in the context of biologics, patents are a cumbersome, inefficient, and often ineffective way of "promot[ing] the Progress of Science and useful Arts."206 FDA granted statutory exclusivities under BPCIA, on the other hand, appear to be more comprehensive and easily enforceable, significantly reduce costs involved in litigation, are less prone to abuse, and create legal certainty that is currently missing from the protection of technological innovation under patent law.

Furthermore, statutory exclusivities guarantee that only "worthy technologies" are granted monopolies. A constant concern in the context of technological advances is that monopoly grants may be squandered on "unworthy" technologies. For instance, it is not uncommon that inventions that lack any value to society are granted patents just because they happen to "satisfy" the requirements of patent law. ${ }^{207}$ As opposed to the patent examination process, which mostly utilizes standards not directly relevant to any particular technology, evaluation of new technologies by specialized agencies directly gauges the "social worth" of such technologies.

The FDA's expertise and understanding in the area of biologics enables it to evaluate the potential medical benefits of biologics and weigh them against possible risks, thereby directly determining the true societal value of specific biological products. ${ }^{208}$ The patent system, on the other hand, utilizes an array of arguably irrelevant "surrogate" or "proxy" standards to indirectly appraise the societal value of advancements, including biological products. ${ }^{209}$ Thus, at least in the context of biologics, a statutory exclusivities regime has an economic advantage over a patent regime as it is more likely to guarantee that monopolies are only awarded for "socially valuable" technologies.

205. See supra Part III.C.1.

206. U.S. ConsT. art. I, $\$ 8, \mathrm{cl} .8$.

207. There is no shortage of examples of what may be described as ridiculous patents covering socially worthless technologies. See, e.g., America's Goofiest Patents, Totally ABSURD INVENTIONS, http://totallyabsurd.com (last visited Feb. 8, 2012).

208. Direct examination by the FDA presumably guarantees that pharmaceuticals only receive monopoly via statutory exclusivities based on the criterion of whether they carry sufficient benefit to the public health per se rather than based on surrogate criteria for measuring their social worth, which may or may not guarantee that they actually convey any benefit to the public.

209. For example, novelty, nonobviousness, written description, and enablement. See 35 U.S.C.A. $\$ \$ 101-103,112$ (West 2012). The FDA evaluation is directed at the crux of the issue of benefit for the public, namely, whether the biological product is safe and efficacious enough to be approved as a medicine and therefore merits statutory exclusivity, regardless of whether or not a hypothetical person of ordinary skill in the art would have found it obvious or in compliance with other seemingly irrelevant criteria enumerated in patent law. 


\section{A Proposed Amendment to Limit Patent Protection Where BPCIA Statutory Exclusivities Are in Force}

As discussed above, in the area of biologics, a statutory exclusivities regime is preferable to a patent regime. To avoid the negative ramifications of concurrent protection by both statutory exclusivities and patents, it is advisable that upon the onset of the statutory exclusivity period under BPCIA, developers of the approved products would no longer be able to enforce their patents as they pertain to the biological products as approved against generic manufacturers applying for the approval of generic versions of such products ("proposed amendment"). ${ }^{210}$

210. One way of achieving this result would be to amend Title 35 of the U.S. Code to limit section 271 so that it would create causes of action against generic applicants under $\mathrm{BPCIA}$ only if no statutory exclusivity under BPCIA is in effect with relation to the product covered by the patent whose enforcement is sought. A possible "softer" version of such a sweeping prohibition of enforcement of pertinent patents is to have developers of biological products elect how to protect their proprietary interests in their products, namely by choosing to benefit from the statutory exclusivities scheme afforded under BPCIA or having the ability to enforce their patents covering the underlying technologies in the approved biological product against generic applicants. To implement this "softer" version of the proposed amendment, BPCIA could be amended to stipulate that the FDA would refrain from taking the actions related to the approval of generic versions of the biological products as prescribed under BPCIA $\$ 7002$ (a) (codified at 42 U.S.C.A. $\$ 262(\mathrm{k})(7)$ (West 2012)) only pursuant to a commitment by a BLA applicant to be estopped from enforcing its patents pertaining to the approved biological product against such generic applicants or so long as developers of biological products do not seek enforcement of their patents covering inventions pertaining to their biological products against parties seeking approval for generic versions of such products in accordance with BPCIA. See supra notes 84-85 and accompanying text. This "softer" version may circumvent possible challenges of the proposed amendment as an unconstitutional taking of one's proprietary rights in one's patents in violation of the Fifth Amendment of the Constitution. Importantly, this amendment is not meant to prevent developers of biological products from enforcing their patents against later applicants seeking approval not under BPCIA. Namely, developers of biological products would still be able to sue for infringement of their patents where a competitor might seek FDA approval of the same biological compound for the treatment of the same medical condition by conducting their own clinical trials, i.e., without relying on the approval of the original biological product under BPCIA.

A possible question is why leaving things the way they are, namely "for the market to take care of," would not provide a sufficient and satisfying solution to the problems discussed above arising out of affording double protection to original biological products under both patent and statutory exclusivities regimes. Arguably, if patents are "so deficient" as a means of protecting one's proprietary interests in biological products that alternative means-completely outside of patent law-are necessary to incentivize R\&D of biologics, then developers of original biological products would be unlikely to seek or pursue enforcement of any patents covering their biological products and the whole issue of double protection would be moot. However, the need for the proposed measure limiting the protection afforded to original biological products is the risk of abuse of patent law (rather than its use for the purposes for which it was intended). In other words, allowing developers of original biological products to benefit, in the broad sense, from both patent and statutory exclusivity regimes might lead to their using the exclusivities under BPCIA for their intended purpose but misusing the protection afforded to their products under patent law in a manner that does not comport with the purpose for which patents were created. The measures proposed herein seek to eliminate the risk of such patent 
Importantly, this proposal would "strip" biological products of any additional period of protection under their primary patents subsequent to the expiration of the market exclusivity under BPCIA. ${ }^{211}$ The potential loss ${ }^{212}$ of this additional protection under patent law (flawed and partial as it may $b^{213}$ ) is justified because it reflects payment for insurance embodied in the statutory exclusivities afforded under BPCIA. ${ }^{214}$ In other words, developers of original biological products would surrender about 5 to 11 months on average of exclusivity under patent law in return for 12 to 12.5 years of litigation-free and other legal risks'-free market exclusivity (and 4 to 4.5 years of data exclusivity).

Further, making it impossible for developers of original biological products to enforce their primary patents against generic applicants filing for generic versions of biological products under BPCIA (including after the expiration of the market exclusivity period) would prevent "double dipping" by developers of original biological products. ${ }^{215}$ Arguably, the length of the market exclusivity period granted under BPCIA $^{216}$ should be sufficient to incentivize R\&D in the area of biological pharmaceuticals. There is no justification for "windfalls" in the form of additional monopoly periods conferred by primary patents extending beyond the end of the market exclusivity period in some of the biological products that would further curb public access to these products. ${ }^{217}$

abuse by making patent enforcement unavailable in a narrowly defined set of circumstances without derogating from the incentives for R\&D of biological products.

211. See supra Part III.B.

212. In particular, the five- to eleven-month term of primary patents beyond the expiration of the market exclusivity period under BPCIA is an average number. Thus, while some products would probably be covered by primary patents whose term is more than five to eleven months beyond the market exclusivity period under BPCIA, other products may only be covered by primary patents (if any) whose term is shorter than the market exclusivity period under BPCIA. See infra note 217.

213. See discussion supra Part III.C.1.

214. See discussion supra notes 92 and 143 and accompanying text.

215. To clarify, "double dipping" in this context would be the benefit from both patent and statutory exclusivities regimes in the context of approval of generic biologics under BPCIA.

216. The length of the market exclusivity period of 12 to 12.5 years under BPCIA is in line with the proposals raised by original biologics industry advocates as necessary for the industry to maintain proper incentives for R\&D. See supra notes 72-73 and accompanying text.

217. For example, of the seventy-nine products listed in Table 1, fifty-three of the products would have primary patent terms extending beyond the end of the 12-year market exclusivity, while twenty-six of them would not (the ratio shifts to forty-nine to thirty for a market exclusivity period of 12.5 years).

Importantly, primary patents covering biological products (which would, under the proposal herein, be unenforceable against generic manufacturers seeking approval of their products under $\mathrm{BPClA}$ ) would still be enforceable against independent developers of the same biological product and third parties who do not seek to utilize the BPCIA framework and who would therefore not be subject to BPCIA's statutory exclusivities provisions. 
The proposed amendment is unlikely to discourage continued R\&D of approved biological products (which is intended to lead to improvements of approved biological products and, possibly, to the development of new ones). ${ }^{218}$ This is because the proposed amendment would only apply to patents that cover biological products as originally approved by the FDA. ${ }^{219}$ To avoid unnecessary legal disputes, there may also be merit in explicitly limiting the proposed amendment so that it would only apply to primary patents and would not prevent enforcement of secondary patents covering inventions stemming from continued R\&D. ${ }^{220}$ Such explicit limitation, while potentially opening the door to abundant litigation involving secondary patents (with all of its risks of evergreening and patent abuse), would assist in providing the necessary incentive for continued $R \& D$ of already-approved biologics, which is currently missing from BPCIA. An alternative solution to the problem of lack of incentive for continued R\&D of already-approved biological products would be to amend 42 U.S.C. $\$ 262(\mathrm{k})(7)(\mathrm{c})(\mathrm{ii})(\mathrm{II})$ so as to allow for an additional short period of market exclusivity for the approval of additional medical indications for already-approved biological products similar to that afforded under the three-year additional statutory exclusivity period granted under the Hatch-Waxman Act. ${ }^{221}$

218. It is common in the context of pharmaceuticals that primary patents applied for early in a product's development process are followed by additional patents claiming (1) particular ways of formulating the product, (2) additional methods of manufacturing the API or any of the intermediate compounds involved in making it and (3) additional methods of using the product or API for treating additional medical conditions [hereinafter "secondary patents"]. For example, the biologic Enbrel, which was originally approved for the treatment of rheumatoid arthritis, later proved effective in the treatment of other autoimmune diseases such as psoriasis and Crohn's disease; Avastin, which was originally approved for treatment of colorectal cancer, was later approved for treating non-small cell lung cancer and breast cancer. See DiMasi \& Grabowski 2009, supra note 5, at 4-5 (arguing that new indications are an important source of innovative advances in biologics); Grabowski 2009, supra note 5, at 4 (reviewing three drugs approved for one condition that were later approved for other conditions).

219. In the "softer" version mentioned earlier, BLA holders should be estopped only from enforcing patents covering the original formulation of the approved biologic, the originally approved indications, the original structure of the biological API, etc. See supra note 210.

The author is aware that in leaving an opening for additional monopoly periods subsequent to the expiration of the 12- to 12.5-year statutory exclusivity period in biological products there remains a risk of abuse by evergreening, which would likely need to be addressed in litigation.

220. Since there is clear societal interest in encouraging such continued R\&D, there is merit in offering additional incentives for such research in the form of either patents or statutory exclusivities. As explained earlier, statutory exclusivities under BPCIA are unavailable for most types of modifications of a previously-approved biological product. See supra notes 200202 and accompanying text. Yet, patents may still be available-limited and insufficient as they might be--as a means of incentivizing invention, investment in R\&D, and disclosure of technology in the context of pharmaceuticals. See supra Parts III.C.1.a, III.C.I.b, III.C.1.d. By limiting the proposed amendments to primary patents, it would be possible to preserve patents as means of encouraging further R\&D of already-approved biological products.

221. See supra text accompanying notes $30,204$. 
The proposed amendment could also raise concerns that the limitations it imposes on patent recourse might contradict undertakings by the United States under patent treaties not to deny patent protection to classes of technologies as such. ${ }^{222}$ However, arguably, the proposed amendment would not deny protection but rather create a quid pro quo arrangement wherein in order to benefit from statutory exclusivities under BPCIA, developers of biological products would only be limited in enforcement of their (undeniable) patent rights under a narrow set of circumstances. ${ }^{223}$

Finally, the proposed amendment would not seem to be at odds with the Intellectual Property Clause of the Constitution, that "Congress shall have Power to promote the Progress of Science and useful Arts, by securing for limited Times to ... Inventors the exclusive Right to their ... Discoveries," 224 as the constitutional language does not grant a positive right to obtain patents as such. Rather, the Intellectual Property Clause authorizes Congress to devise means of promoting the progress of science and useful arts as it sees fit, which is exactly what BPCIA does and would continue to do with the proposed amendment. ${ }^{225}$ Furthermore, if the legal situation remains in its present state, and developers of biological products continue to be able to utilize both patents and statutory exclusivities concurrently to protect their proprietary interests in their products, one could argue that the cumulative protection afforded in biological products is too strong and operates to

222. For example, the North American Free Trade Agreement (NAFTA) stipulates that "each Party shall make patents available for any inventions, whether products or processes, in all fields of technology." North American Free Trade Agreement art. 1709(1), Dec. 17, 1992, 32 I.L.M. 605 (NAFTA); see also General Agreement on Tariffs and Trade Uruguay Round Agreement on Trade-Related Aspects of Intellectual Property Rights Including Trade in Counterfeit Goods, art. 27(1), Apr. 15, 1994, 1994 WL 1711191 (TRIPS) ("patents shall be available and patent rights enjoyable without discrimination as to . . the field of technology ...."); 2000 CRS REPORT, supra note 168, at 26-27 (" $[t]$ he potential for limiting the patentability of living inventions is moderated by several factors. One source of restraints consists of international agreements to which the United States is a signatory.").

223. This challenge could also be overcome by adopting the "softer" version of the proposed amendment, under which it would be developers of biological products who would have the option to pursue their rights under patent law or benefit from the statutory exclusivities scheme under BPCIA.

224. See U.S. ConST. art. I, $\$ 8, \mathrm{cl} .8$.

225. Once again, the "softer" version of the proposed amendment could resolve any constitutional difficulty that may arise in this regard under more conservative constitutional construction. Namely, even if one is to construe Article 1, Section 8 , Clause 8 of the Constitution narrowly as only granting Congress the ability to "secure []$\ldots$ to ... Inventors ... exclusive Rights" (rather than deny such rights), under the proposed amendments inventors would choose to benefit from statutory exclusivities by electing to refrain from enforcing their patents. In other words, it would not be Congress that would deny the inventors' ability to "secur[e] . . . exclusive [r]ights," but rather the inventors themselves who would be making the choice to limit their own already "secure[d] ... exclusive [patent r]ights" in exchange for the ability to benefit from the statutory exclusivities afforded under BPCIA. 
obstruct the progress of science and useful arts in abrogation of the Intellectual Property Clause.226

\section{Why Patents Still Have a Role to Play in Incentivizing $R \& D$ in Biologics}

The above conclusions and proposed amendment raise the following question: if statutory exclusivities are so clearly preferable to patents in the context of biological products and if patents are not only deficient but possibly even harmful to the interests of developers of biological products and public interest alike, wouldn't it simply be better to forego patent protection in biological products altogether?

The answer to this question is no. Despite patents' numerous shortcomings and the clear advantages statutory exclusivities have over them, patents still have important functions to fulfill in incentivizing the development of biological products during the period prior to the approval of biological products by the FDA. Patents serve an important fundraising tool, which enables $R \& D$ entities to raise the funds necessary to support their research projects. ${ }^{227}$ In this respect patents have a vital function in the development of pharmaceutical products and, even more so, of biological products-given their high R\&D costs-as they make it possible for developers of such products to raise the funds necessary to traverse the numerous expensive steps of clinical development prior to being eligible to benefit from the statutory exclusivities under BPCIA (subsequent to approval of the biological product by the FDA).

A possible explanation of the "sway" patents may have in convincing investors to commit funds to certain $\mathrm{R} \& \mathrm{D}$ projects is their ability to prevent situations of a "race to register." 228 In this respect, patents serve not only as a signaling device between companies but also as means of blocking one's competitors from entering into such a "race to register" in the first place. This explanation appears to be especially valid in the context of the biologics industry, which consists of a significant portion of small to medium R\&D firms. In "race to register" situations, patents improve the survivability of such small to medium R\&D firms competing against major pharmaceutical corporations during the development stages of biological products prior

226. Such arguments can rely on the various ways in which patents could be abused and misused in an anti-competitive manner. See supra Part III.C.2.b. A constitutional analysis of Congress's power to create the statutory exclusivity scheme under BPCIA appears to merit further analysis, which exceeds the scope of this Article.

227. Although patents may not provide any additional monopoly period to that afforded by the statutory exclusivities under BPCIA, or directly attest to the prospects of success of an R\&D project that may lead to a biological product, they carry substantial weight with investors.

228. A "race to register" occurs when two companies undertake a similar research project and are competing to have their respective products approved by the FDA first. 
to their approval by the FDA. ${ }^{229}$ Thus, patents make it possible for small to medium R\&D outfits to stay in the market to see another day (and, perhaps, another research project). ${ }^{230}$

Accordingly, during the period prior to approval of biological products by the FDA and the onset of statutory exclusivities under BPCIA, patents would actually serve as "insurance policies" that make the achievement of statutory exclusivities possible further down the road. In addition, as discussed earlier, follow-on patents also have an important role to play subsequent to the expiration of statutory exclusivity periods under BPCIA. ${ }^{231}$ To summarize: there is merit in affording biological products sequential (rather than concurrent) protection from (1) any primary patents pertaining to the underlying technology in such products prior to the onset of statutory exclusivities under BPCIA, (2) statutory exclusivities in the FDA approved products themselves, and (3) any secondary patents pertaining to substantial ${ }^{232}$ further developments of the originally approved biological product.

\section{Statutory Exclusivities in Biological Products-A Peculiar Case or the Future OF INCENTIVIZING INNOVATION?}

In view of the foregoing conclusions one cannot help but wonder: is the regulation of generic biologics a harbinger of a new type of intellectual property regime wherein patents and statutory exclusivities work in tandem to incentivize R\&D? Can we expect to see similar regimes put in place with respect to other areas of technology? And are there areas of technology in which it would be desirable to replace the traditional patent regime with a new regime of statutory exclusivities altogether? As "the pattern of technical advance varies significantly from field to field" and from one industry to another, ${ }^{233}$ statutory exclusivity frameworks would not necessarily be similarly suitable for all fields and industries. However, it is quite possible that because of their lower transaction costs and the legal certainty they provide, statutory exclusivities could complement

229. Since large corporations usually have more resources, it is expected that with everything else being equal, they will almost always "win" in "race-to-register" situations.

230. Alternatively, early patent applications and patents issued from them make it possible for small to medium R\&D firms to get, at the very least, through the initial proof-ofconcept or pre-clinical testing stages that enable them to sell their research projects to major pharmaceutical corporations.

231. See supra notes 218-221 and accompanying text.

232. The inclusion of the "substantiality" language is meant to clarify that sequential protection of insubstantial developments of the biological product-which are essentially evergreening-are not within the scope of legitimate sequential patent protection described herein.

233. See Robert P. Merges \& Richard R. Nelson, On the Complex Economics of Patent Scope, 90 Colum. L. Rev. 839, 880 (1990). 
patents in some areas of technology and possibly even obviate patents altogether in others. It is thus beneficial to make some observations regarding the characteristics of areas of technology that may be "candidates" for such a change in technology-protection regime. ${ }^{234}$

Yet, before making any such observations, it is worth highlighting two prerequisites for the administration of statutory exclusivities regimes. First, to be a "candidate" for implementation of a statutory exclusivity framework, a technological area must-just like in the area of pharmaceuticals-be subject to regulation by a dedicated and qualified impartial body, e.g., an executive agency capable of administering the regulatory framework instituting the exclusivities regime. Such a body ought to routinely regulate the pertinent technological area or have direct bearing on that particular area and must have a substantial amount of expertise in evaluating technologies in that area. Given its particular expertise, arguably, such a body would be better suited than the USPTO to evaluate relevant technologies in its area of expertise and would therefore be in a better position to make merit assessments with respect to such technologies from a public benefit perspective.

A second prerequisite for the implementation of statutory exclusivities regimes is that the practical application of technology in the regulated area requires some kind of regulatory approval or the removal of a regulatory bar. This requirement is essential for the administration of statutory exclusivities regimes because it is the withholding of the approval to use the technology or the imposition of the regulatory bar that effectuates the exclusivities. Notably, once a technological area is recognized as a potential candidate for the implementation of a statutory exclusivity framework, it is possible to fulfill the aforementioned prerequisites-the regulation of the technological area by a dedicated and qualitied impartial body and the existence of a requirement for regulatory approval or removal of a regulatory bar in order to put technology in that area into practical application-via appropriate legislation.

Statutory exclusivities regimes would be suitable primarily in areas of technology in which (1) additional incentives to invent are necessary because the existing incentives provided under patent law are insufficient, or (2) the circumstances of the particular market pertaining to the regulated technological area lend themselves to inefficiencies such as abuse of market share. Statutory exclusivities regimes ought not to be considered in areas that do not call for additional incentives, e.g., areas in which development of technology is relatively cheap, does not require substantial amounts of know-how and expertise, or the risks of not recouping one's investments are

234. Such an approach is in concert with the Federal Circuit's general approach of adapting the legal framework to particular areas of technology. See Aljalian, supra note 155, at 18-19 ("[P]atent scope has come to be largely dependent on the technology at issue. The Federal Circuit actively tailors patent law and policy to the technology under consideration. This new approach is viewed as having 'a significant impact' on advances in technology and various industries."). 
low. ${ }^{235}$ Ideally, statutory exclusivities regimes should be implemented in technological areas that have high entry barriers-financial, technological, or both-and where the prospects of return on investment are unpredictable or involve substantial risks.

As for the question of when, if ever, statutory exclusivities should replace patents altogether, it is difficult to establish a bright line rule regarding the circumstances that would necessitate and justify such replacement. However, as stated above, it is possible to propose some parameters that would, potentially, assist in identifying technological areas that may be suitable for excepting technology from protection under patent law in favor of protection under a statutory exclusivities regime. Presumably, these areas would be those that exhibit extreme cases of the aforementioned characteristics, namely where patent protection provides very little to no incentives (or even negative incentives ${ }^{236}$ ) to invent/invest or to disclose new technology or where the market in the technology that utilizes the pertinent technology is plagued by constant inefficiencies. Statutory exclusivities may be especially fitting as a replacement for patents in technological areas that are particularly susceptible or prone to patent abuse.

Notably, the implementation of statutory exclusivities regimes itself is also not devoid of risks of inefficiencies and abuse. Because statutory exclusivities regimes are based on reliance on expert regulators, risks of regulatory or agency capture become more prominent. ${ }^{237}$ In the context of approvals of pharmaceutical products by the FDA, for example, this risk is evident in the fact that FDA personnel is in regular contact with representatives of certain corporations who are prominent and repeated actors in the regulated area and who are also, frequently, former members of the FDA staff themselves. Being aware of such risks of regulatory or agency capture is therefore essential in making sure that there are sufficient checks within agencies that are to administer statutory exclusivities regimes that may be provided for by appropriate institutional design. ${ }^{238}$

Examples of areas that meet the above criteria and may be suitable for the application of statutory exclusivities in addition to or in lieu of patents are the regulation of foods, cosmetics, veterinary pharmaceuticals and

235. Awarding statutory exclusivities in areas that do not require further incentives to invent, invest in $R \& D$, or disclose technology might work to achieve the opposite results.

236. Hypothetically, there could be areas of technology where the traditional patent regime is so deficient that it actually creates negative incentives to invent/invest or disclose, in which case patent protection should be forgone and a statutory exclusivities regime ought to be made the sole method of protecting technology.

237. Regulatory or agency capture occurs when a regulatory body or agency created to regulate certain industries or sectors in the public's interest instead advances the commercial or special interests of the industries or sectors it is charged with regulating.

238. See generally Rachel E. Barkow, Insulating Agencies: Avoiding Capture Through Institutional Design, 89 TEx. L. REv. 15 (2010). 
vaccines, ${ }^{239}$ medical devices ${ }^{240}$ and diagnostics, and plant breeds. ${ }^{241}$ It is quite possible that technological advancements in other areas and regulation thereof would render more and more areas of technology candidates for supplementation (or possibly even replacement) of the traditional patent regime with statutory exclusivities.

\section{Conclusion}

The most important function of patents and statutory exclusivities alike is to ensure that those partaking in technological $R \& D$ not only survive to continue their activity but also prosper and seek to continue their R\&D activities in the future. However, in some technological areas, patents might not serve this purpose as well as statutory exclusivities.

This Article does not purport to propose a "patentless world" or portray patents as dinosaurs-ancient relics of a once glorious past. As explained above, statutory exclusivities would and should only serve as an addition to patents in a narrow class of well-defined circumstances; the emergence of statutory exclusivities should not be perceived as hailing the demise of the patent system. Yet, at least in some technological areas, patents may be a less than preferable way of promoting innovation and should be substituted by statutory exclusivities where possible. ${ }^{242}$ Thus, this Article advocates the substitution of patent enforcement rights with statutory exclusivities of appropriate lengths in those areas where there is a regulatory body capable of evaluating and granting licenses to partake in activities involving particular types of patentable technologies and in which the public has an interest in encouraging further technological development. ${ }^{243}$ Biologics represent such a case.

239. See generally Animal Health: Veterinary Biologics, USDA-APHIS (June 14, 2010), http://www.aphis.usda.gov/animal_health/vet_biologics.

240. See generally 5lok Clearances, Food \& DRUG ADMin. (June 18, 2009), http://www.fda.gov/MedicalDevices/ProductsandMedicalProcedures/DeviceApprovalsandCle arances $/ 510 \mathrm{kClearances} /$ default.htm.

241. All of these areas are regulated by the Department of Agriculture (DA) and the FDA in the Department of Health and Human Services (DHHS).

242. See 2008 CRS REPORT, supra note 1, at 20 (recognizing that patents may not be "the most successful mechanism for capturing the benefits of investment" in every industry and arguing that " $[t]$ he utility of patents to companies varies among industrial sectors").

243. This proposition coincides with the belief that

[w] hile the student of the economics of the patent system must, provisionally, disqualify himself on the question of the effects of the system as a whole on a large industrial economy, he need not disqualify himself as a judge of proposed changes in the existing system. While economic analysis does not yet provide a basis for choosing between "all or nothing," it does provide a sufficiently firm basis for decisions about "a little more or a little less" of various ingredients of the patent system.

Economic Review of Patent System, supra note 11, at 80. 
In the context of generic biologics, as soon as the statutory exclusivities instituted by BPCIA kick in, they render primary patents redundant and, by comparison, an inferior way of ensuring the proprietary interests of developers of biological products in their technology. The statutory exclusivities afforded under BPCIA have been tailored to the needs of developers of biological products in the context of generic competition and should thus be held as sufficient for accommodating those needs. Allowing developers of biological products to benefit from the protection of primary patents alongside and concurrent with such statutory exclusivities causes waste and could lead to abuse of the patent system. Further, it is important to remember that patents, despite their long legal history and well-known status as instruments of incentivizing innovation, are only a means to an end. Assuming this "end" is as well or even better served by other means (e.g., statutory exclusivities), patents may lose their allure and become redundant and possibly even harmful. A substitution of primary patent enforcement rights where statutory exclusivities in FDA-approved biological products are in force is the best means to incentivize continued investment in R\&D while guaranteeing sufficient public access to generic versions of biological products. 


\section{APPENDIX}

TABLE $1^{244}$

\begin{tabular}{|c|c|c|c|c|c|c|c|}
\hline I & II & III & IV & $\mathrm{V}$ & VI & VII & VIII \\
\hline $\begin{array}{l}\text { Biological product } \\
\text { (and API) }\end{array}$ & $\begin{array}{l}\text { U.S. } \\
\text { Patent } \\
\text { No. }\end{array}$ & $\begin{array}{c}\text { Patent } \\
\text { application } \\
\text { filing } \\
\text { date }^{245}\end{array}$ & $\begin{array}{c}\text { FDA } \\
\text { approval } \\
\text { date }\end{array}$ & $\begin{array}{c}\text { Patent } \\
\text { expiration } \\
\text { date }^{246}\end{array}$ & $\begin{array}{c}\text { Twelve- } \\
\text { year } \\
\text { market } \\
\text { exclusivity } \\
\text { expiration } \\
\text { date }^{247} \\
\end{array}$ & \begin{tabular}{|} 
Time from \\
patent \\
application \\
to FDA \\
approval $^{248}$
\end{tabular} & $\begin{array}{c}\text { Time from } \\
\text { expiration of } \\
\text { patent term to } \\
\text { end of twelve- } \\
\text { year market } \\
\text { exclusivity }^{249}\end{array}$ \\
\hline $\begin{array}{l}\text { Activase@ } \\
\text { (alteplase) }\end{array}$ & 4766075 & $5 / 5 / 1982$ & $6 / 18 / 1996$ & $8 / 23 / 2005$ & $6 / 18 / 2008$ & 5158 & 1030 \\
\hline $\begin{array}{c}\text { Aldurazyme } 8 \\
\text { (laronidase) }\end{array}$ & 6426208 & $11 / 12 / 1999$ & $4 / 30 / 2003$ & $11 / 12 / 2019$ & $4 / 30 / 2015$ & 1265 & -1657 \\
\hline $\begin{array}{l}\text { Amevive@ } \\
\text { (Alefacept) }\end{array}$ & 5547853 & 3/12/1991 & $1 / 30 / 2003$ & $1 / 30 / 2017$ & $1 / 30 / 2015$ & 4342 & -731 \\
\hline $\begin{array}{l}\text { Angiomax@ } \\
\text { (bivalirudin) }\end{array}$ & 5196404 & $8 / 18 / 1989$ & $12 / 15 / 2000$ & $3 / 23 / 2010$ & $12 / 15 / 2012$ & 4137 & 998 \\
\hline $\begin{array}{l}\text { Apidra@) (insulin } \\
\text { glulisine) }\end{array}$ & 6221633 & $6 / 18 / 1998$ & $4 / 16 / 2004$ & $6 / 18 / 2018$ & $4 / 16 / 2016$ & 2129 & -793 \\
\hline $\begin{array}{c}\text { Aranesp }{ }^{\mathrm{MM}} \\
\text { (darbepoetin alfa) }\end{array}$ & 5856298 & $10 / 13 / 1989$ & $9 / 17 / 2001$ & $1 / 5 / 2016$ & $9 / 17 / 2013$ & 4357 & -840 \\
\hline 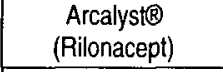 & 5470952 & $10 / 20 / 1993$ & $2 / 27 / 2008$ & $11 / 28 / 2012$ & $2 / 27 / 2020$ & 5243 & 2647 \\
\hline $\begin{array}{c}\text { Avastin }^{\top M} \\
\text { (bevacizumab) }\end{array}$ & 6884879 & $4 / 7 / 1997$ & $2 / 26 / 2004$ & $4 / / / 2017$ & $2 / 26 / 2016$ & 2516 & -406 \\
\hline $\begin{array}{c}\text { Avonex } \begin{array}{c}\text { (interteron } \\
\text { beta-1a; } \\
\text { recombinant) }\end{array} \\
\end{array}$ & 4530901 & $2 / 4 / 1980$ & $5 / 17 / 1996$ & $7 / 23 / 2002$ & $5 / 17 / 2008$ & 5947 & 2125 \\
\hline $\begin{array}{c}\text { BeneFix }{ }^{\mathrm{TM}} \\
\text { (coagulation factor } \\
(\mathrm{X})\end{array}$ & 5171569 & $3 / 13 / 1986$ & $2 / 11 / 1997$ & $2 / 11 / 2011$ & $2 / 11 / 2009$ & 3988 & -730 \\
\hline $\begin{array}{c}\text { Betaseron } \Theta \\
\text { (Interferon beta-1b) }\end{array}$ & 4588585 & $10 / 19 / 1982$ & $7 / 23 / 1993$ & $7 / / / 2007$ & $7 / 23 / 2005$ & 3930 & -714 \\
\hline $\begin{array}{c}\text { Bexxar@ Therapeutic } \\
\text { Regimen } \\
\text { (Tositumomab and } \\
\text { lodine } 1-131 \\
\text { Tositumomab) } \\
\end{array}$ & 5595721 & $9 / 16 / 1993$ & $6 / 27 / 2003$ & $1 / 21 / 2014$ & $6 / 27 / 2015$ & 3571 & 522 \\
\hline $\begin{array}{c}\text { Byetta@ } \\
\text { (exenatide) }\end{array}$ & 5424286 & $5 / 24 / 1993$ & $4 / 28 / 2005$ & $12 / 1 / 2016$ & $4 / 28 / 2017$ & 4357 & 148 \\
\hline
\end{tabular}

244. All times are in days; all time difference calculations were conducted using date calculation tools available at hup://www.timeanddate.com.

245. Filing date is the patent application effective U.S. filing date for term calculation purposes.

246. Patent expiration date includes any term extensions and adjustments.

247. Calculated by adding twelve years to the date of FDA approval (column IV).

248. Calculated as the difference in days between the FDA approval date (column IV) and the patent application filing date (column III).

249. Calculated as the difference in days between the twelve-year market exclusivity expiration date (column VI) and the patent expiration date (column V). 


\begin{tabular}{|c|c|c|c|c|c|c|c|}
\hline I & II & III & IV & V & VI & VII & VIII \\
\hline $\begin{array}{c}\text { Cerezyme® } \\
\text { (imiglucerase) }\end{array}$ & 5236838 & $12 / 23 / 1988$ & $5 / 23 / 1994$ & $8 / 17 / 2010$ & $5 / 23 / 2006$ & 1977 & -1547 \\
\hline $\begin{array}{c}\text { Cimzia® } \\
\text { (Certolizumab pegol) } \\
200 \mathrm{mg} / \mathrm{ml}\end{array}$ & 7094872 & $2 / 19 / 2004$ & $5 / 13 / 2009$ & $7 / 6 / 2024$ & $5 / 13 / 2021$ & 1910 & -1150 \\
\hline $\begin{array}{c}\text { Elaprase } \\
\text { (Idursulfase) }\end{array}$ & 5932211 & $11 / 12 / 1991$ & $7 / 27 / 2006$ & $9 / 3 / 2019$ & $7 / 27 / 2018$ & 5371 & -403 \\
\hline $\begin{array}{c}\text { Elitek@ } \\
\text { (rasburicase) }\end{array}$ & 5382518 & $7 / 13 / 1990$ & $7 / 12 / 2002$ & $7 / 12 / 20+6$ & $7 / 12 / 2014$ & 4382 & -731 \\
\hline $\begin{array}{c}\text { Enbrel®) } \\
\text { (etanercept) }\end{array}$ & RE 36755 & $9 / 5 / 1989$ & 11/2/1998 1 & $10 / 23 / 2012$ & $11 / 2 / 2010$ & 3345 & -721 \\
\hline $\begin{array}{c}\text { Epogen }{ }^{2} \\
\text { (epoietin alfa) }\end{array}$ & 4703008 & $12 / 13 / 1983$ & $6 / 1 / 1989$ & $10 / 27 / 2004$ & $6 / 1 / 2001$ & 1997 & -1244 \\
\hline $\begin{array}{c}\text { Erbitux }^{\mathrm{TM}} \\
\text { (cetuximab) }\end{array}$ & 7060808 & $6 / 7 / 1995$ & $2 / 12 / 2004$ & $6 / 7 / 2015$ & $2 / 12 / 2016$ & 3172 & 250 \\
\hline $\begin{array}{c}\text { Fabrazyme } \\
\text { (agalsidase beta) }\end{array}$ & 5356804 & $10 / 24 / 1990$ & $4 / 24 / 2003$ & $9 / 27 / 2015$ & $4 / 24 / 2015$ & 4565 & -156 \\
\hline $\begin{array}{c}\text { Forteo@ } \\
\text { (teriparatide) }\end{array}$ & 4698328 & $4 / 4 / 1985$ & $11 / 26 / 2002$ & $4 / 4 / 2005$ & $11 / 26 / 2014$ & 6445 & 3523 \\
\hline $\begin{array}{c}\text { Fuzeon } \\
\text { (Enfuvirtide) }\end{array}$ & 6133418 & $6 / / / 1993$ & $3 / 13 / 2003$ & $11 / 17 / 2014$ & $3 / 13 / 2015$ & 3566 & 116 \\
\hline $\begin{array}{c}\text { Geref( (sermoreline } \\
\text { acetate) }\end{array}$ & 4703035 & $10 / 4 / 1982$ & $12 / 28 / 1990$ & $12 / 28 / 2004$ & $12 / 28 / 2002$ & 3007 & .731 \\
\hline $\begin{array}{c}\text { Gonal-F® (follitropin } \\
\text { alfa) }\end{array}$ & 5156957 & $11 / 2 / 1983$ & $9 / 29 / 1997$ & $9 / 29 / 2011$ & 9/29/2009 & 5080 & .730 \\
\hline $\begin{array}{c}\text { Herceptin® } \\
\text { (trastuzumab) }\end{array}$ & 5677171 & $1 / 12 / 1988$ & $9 / 25 / 1998$ & $10 / 14 / 2014$ & $9 / 25 / 2010$ & 3909 & -1480 \\
\hline $\begin{array}{c}\text { Humira }^{\mathrm{TM}} \\
\text { (adalimumab) }\end{array}$ & 6090382 & 2/9/1996 & $12 / 31 / 2002$ & $12 / 31 / 2016$ & $12 / 31 / 2014$ & 2517 & -731 \\
\hline $\begin{array}{c}\text { llaris } \circledast \\
\text { (Canakinumab) }\end{array}$ & 7446175 & $8 / 20 / 2001$ & $6 / 17 / 2009$ & $12 / 22 / 2022$ & $6 / 17 / 2021$ & 2858 & -553 \\
\hline $\begin{array}{c}\text { Increlex }^{\mathrm{TM}} \\
\text { (mecasermin) }\end{array}$ & 5681814 & $6 / 7 / 1990$ & $8 / 30 / 2005$ & $9 / 18 / 2017$ & $8 / 30 / 2017$ & 5563 & -19 \\
\hline $\begin{array}{c}\text { Intergen® } \\
\text { (interferon alfacon-1) } \\
\end{array}$ & 4695623 & $5 / 6 / 1982$ & $10 / 6 / 1997$ & $9 / 22 / 2009$ & $10 / 6 / 2009$ & 5632 & 14 \\
\hline $\begin{array}{c}\text { Intron } A \otimes \\
\text { (alpha-interferon) }\end{array}$ & 4496537 & $12 / 23 / 1981$ & $6 / 4 / 1986$ & $1 / 29 / 2002$ & $6 / 4 / 1998$ & 1624 & -1335 \\
\hline $\begin{array}{c}\text { Iplex }{ }^{\text {TM }} \text { (mecasermin } \\
\text { rinfabate [rDNA } \\
\text { origin]) }\end{array}$ & 5681818 & $3 / 31 / 1988$ & $12 / 12 / 2005$ & $5 / 11 / 2019$ & $12 / 12 / 2017$ & 6465 & -515 \\
\hline $\begin{array}{l}\text { Kepivance® } \\
\text { (palifermin) }\end{array}$ & 5677278 & $6 / 29 / 1993$ & $12 / 15 / 2004$ & $10 / 14 / 2014$ & $12 / 15 / 2016$ & 4187 & 793 \\
\hline $\begin{array}{l}\text { Kineret }^{\mathrm{TM}} \\
\text { (anakinra) } \\
\end{array}$ & 5075222 & $5 / 27 / 1988$ & $11 / 14 / 2001$ & $12 / 24 / 2013$ & $11 / 14 / 2013$ & 4919 & -40 \\
\hline $\begin{array}{c}\text { Lantus } \circledast \\
\text { (insulin glargine) }\end{array}$ & 5101013 & $8 / 9 / 1988$ & $4 / 20 / 2000$ & $12 / 3 / 2011$ & $4 / 20 / 2012$ & 4272 & 139 \\
\hline $\begin{array}{c}\text { Leukine } \\
\text { (Sargramostim - } \\
\text { granulocyte } \\
\text { macrophage colony- } \\
\text { stimulating factor) } \\
\end{array}$ & 5391485 & $8 / 6 / 1985$ & $3 / 5 / 1991$ & 2/21/2012 & $3 / 5 / 2003$ & 2037 & -3275 \\
\hline
\end{tabular}




\begin{tabular}{|c|c|c|c|c|c|c|c|}
\hline I & II & III & IV & V & VI & VII & VIII \\
\hline $\begin{array}{c}\text { Lucentis® } \\
\text { (Ranibizumab) }\end{array}$ & 6884879 & $4 / / / 1997$ & $6 / 30 / 2006$ & $4 / / 2017$ & $6 / 30 / 2018$ & 3371 & 449 \\
\hline $\begin{array}{l}\text { Luveris@ (lutropin } \\
\text { alfa for injection) }\end{array}$ & 5639639 & $11 / 2 / 1983$ & $10 / 8 / 2004$ & $6 / 20 / 2011$ & $10 / 8 / 2016$ & 7646 & 1937 \\
\hline $\begin{array}{c}\text { Macugen } \circledast \text { ) } \\
\text { (pegaptanib) }\end{array}$ & 6051698 & $\begin{array}{l}\text { 6 June } \\
1997\end{array}$ & $12 / 17 / 2004$ & $5 / 19 / 2015$ & $12 / 17 / 2016$ & 2751 & 578 \\
\hline $\begin{array}{c}\text { Mircera } ® \\
\text { (Methoxypolyethylen } \\
\text { e glycol epoetin } \\
\text { beta) }\end{array}$ & 6583272 & $6 / 27 / 2000$ & $11 / 11 / 2007$ & $8 / 26 / 2020$ & $11 / 11 / 2019$ & 2697 & -289 \\
\hline $\begin{array}{c}\text { Myobloc@ } \\
\text { (Botulinum Toxin } \\
\text { Type B) }\end{array}$ & 6290961 & $12 / 28 / 1993$ & $8 / 12 / 2000$ & $12 / 28 / 2013$ & $8 / 12 / 2012$ & 2419 & .503 \\
\hline $\begin{array}{c}\text { Myozyme } \Theta \\
\text { (Alglucosidase alfa) }\end{array}$ & 7351410 & $12 / 6 / 1999$ & $4 / 28 / 2006$ & $10 / 29 / 2020$ & $4 / 28 / 2018$ & 2335 & -915 \\
\hline $\begin{array}{c}\text { Naglazyme } 8 \\
\text { (Galsulfase) }\end{array}$ & 6972124 & $5 / 1 / 2000$ & $5 / 31 / 2005$ & $7 / 17 / 2020$ & $5 / 31 / 2017$ & 1856 & -1143 \\
\hline $\begin{array}{l}\text { Natrecor } 8 \\
\text { (nesiritide) }\end{array}$ & 5114923 & $5 / 31 / 1988$ & $8 / 10 / 2001$ & $5 / 19 / 2014$ & $8 / 10 / 2013$ & 4819 & .282 \\
\hline $\begin{array}{c}\text { Neulasta }^{T M} \\
\text { (pegfilgrastim) }\end{array}$ & 5582823 & $8 / 23 / 1985$ & $1 / 31 / 2002$ & $12 / 10 / 2013$ & $1 / 31 / 2014$ & 6005 & 52 \\
\hline $\begin{array}{l}\text { Neumega } \bigotimes \\
\text { (oprelvekin) }\end{array}$ & 5215895 & $11 / 22 / 1989$ & $11 / 25 / 4997$ & $11 / 25 / 2011$ & $11 / 25 / 2009$ & 2925 & -730 \\
\hline $\begin{array}{l}\text { Neupogen® } \\
\text { (filgrastim) }\end{array}$ & 4810643 & $8 / 23 / 1985$ & $2 / 20 / 1991$ & $3 / / 2006$ & $2 / 20 / 2003$ & 2007 & -1111 \\
\hline $\begin{array}{c}\text { Nplate@ } \\
\text { (Romiplostim) }\end{array}$ & 6835809 & $10 / 22 / 1999$ & $8 / 22 / 2008$ & $10 / 22 / 2019$ & $8 / 22 / 2020$ & 3227 & 305 \\
\hline $\begin{array}{c}\text { Orencia }^{\text {TM }} \\
\text { (abatacept) }\end{array}$ & 5851795 & $6 / 27 / 1991$ & $12 / 23 / 2005$ & $11 / 25 / 2017$ & $12 / 23 / 2017$ & 5293 & 28 \\
\hline $\begin{array}{l}\text { Orthoclone OKT3® } \\
\text { (muromonab-CD3) }\end{array}$ & 4361549 & $4 / 26 / 1979$ & $9 / 14 / 1992$ & $11 / 30 / 1999$ & $9 / 14 / 2004$ & 4890 & 1750 \\
\hline $\begin{array}{c}\text { Ovidrel@ (human } \\
\text { chorionic } \\
\text { gonadotropin) }\end{array}$ & 4840896 & $11 / 2 / 1983$ & $9 / 20 / 2000$ & $4 / 29 / 2009$ & $9 / 20 / 2012$ & 6167 & 1240 \\
\hline $\begin{array}{c}\text { PEG-Intron }{ }^{\mathrm{TM}} \\
\text { (pegylated interferon } \\
\text { alfa-2b) }\end{array}$ & 5951974 & $11 / 10 / 1993$ & $1 / 19 / 2001$ & $1 / 19 / 2015$ & $1 / 19 / 2013$ & 2627 & -730 \\
\hline $\begin{array}{c}\text { Proleukin, IL-2@ } \\
\text { (aldesleukin) }\end{array}$ & RE33653 & $10 / 19 / 1982$ & $5 / 5 / 1992$ & $5 / 5 / 2006$ & $5 / 5 / 2004$ & 3486 & .730 \\
\hline $\begin{array}{c}\text { ProstaScint@(Capro } \\
\text { mab Pendetide) }\end{array}$ & 5162504 & $6 / 3 / 1988$ & $10 / 28 / 1996$ & $10 / 28 / 2010$ & $10 / 28 / 2008$ & 3069 & -730 \\
\hline $\begin{array}{c}\text { Raptiva }^{\mathrm{TM}} \\
\text { (efalizumab) }^{\text {(efub }}\end{array}$ & 6037454 & $11 / 20 / 1997$ & $10 / 27 / 2003$ & $11 / 20 / 2017$ & $10 / 27 / 2015$ & 2167 & -755 \\
\hline $\begin{array}{c}\text { ReFacto } \\
\text { (antihemophilic } \\
\text { factor) }\end{array}$ & 4868112 & $4 / 12 / 1985$ & $3 / 1 / 2000$ & $2 / 28 / 2010$ & $3 / 1 / 2012$ & 5437 & 732 \\
\hline $\begin{array}{c}\text { Regranex@ } \\
\text { (Becaplermin) }\end{array}$ & 4845075 & $2 / 25 / 1985$ & $12 / 16 / 1997$ & $10 / 29 / 2010$ & $12 / 16 / 2009$ & 4677 & -317 \\
\hline $\begin{array}{l}\text { Remicade } B \\
\text { (infliximab) }\end{array}$ & 5656272 & $3 / 18 / 1991$ & $8 / 24 / 1998$ & $8 / 12 / 2014$ & $8 / 24 / 2010$ & 2716 & .1449 \\
\hline
\end{tabular}




\begin{tabular}{|c|c|c|c|c|c|c|c|}
\hline$I$ & II & III & IV & V & $\mathrm{VI}$ & VII & VIII \\
\hline $\begin{array}{c}\text { Remodulin }^{\mathrm{TM}} \\
\text { (treprostinil sodium) }\end{array}$ & 5153222 & $6 / 16 / 1989$ & $5 / 21 / 2002$ & $10 / 6 / 2014$ & $5 / 21 / 2014$ & 4722 & -138 \\
\hline $\begin{array}{l}\text { Retavase }^{\mathrm{TM}} \\
\text { (reteplase) }^{\text {(n) }}\end{array}$ & 5223256 & $2 / 6 / 1990$ & $10 / 30 / 1996$ & $10 / 30 / 2010$ & $10 / 30 / 2008$ & 2458 & -730 \\
\hline $\begin{array}{l}\text { Rituxan } \\
\text { (rituximab) }\end{array}$ & 5763137 & 7/29/1996 & $11 / 26 / 1997$ & $7 / 29 / 2016$ & $11 / 26 / 2009$ & 485 & -2437 \\
\hline $\begin{array}{c}\text { Roferon } \\
\text { (Interferon alfa-2a) }\end{array}$ & 4503035 & $11 / 24 / 1978$ & $4 / 6 / 1986$ & $3 / 5 / 2002$ & $4 / 6 / 1998$ & 2690 & -1429 \\
\hline $\begin{array}{c}\text { Simulect } \mathbb{8} \\
(\text { Basiliximab) }\end{array}$ & 6521230 & $3 / 14 / 1991$ & $12 / 5 / 1998$ & $2 / 18 / 2020$ & $12 / 5 / 2010$ & 2823 & -3362 \\
\hline $\begin{array}{c}\text { Soliris@ } \\
\text { (Eculizumab) }\end{array}$ & 6074642 & $5 / 2 / 1994$ & $3 / 16 / 2007$ & $5 / 2 / 2014$ & $3 / 16 / 2019$ & 4701 & 1784 \\
\hline $\begin{array}{c}\text { Somavert@ } \\
\text { (pegvisomant) }\end{array}$ & 5849535 & $9 / 21 / 1995$ & $3 / 25 / 2003$ & $3 / 25 / 2017$ & $3 / 25 / 2015$ & 2742 & -731 \\
\hline $\begin{array}{c}\text { Stelara }^{\mathrm{TM}} \\
\text { (Ustekinumab) }\end{array}$ & 6902734 & $8 / 1 / 2001$ & $9 / 25 / 2009$ & $7 / 26 / 2022$ & $9 / 25 / 2021$ & 2977 & -304 \\
\hline $\begin{array}{c}\text { Synagis }^{\mathrm{TM}} \\
\text { (palivizumab) }\end{array}$ & 5824307 & $12 / 23 / 1991$ & $6 / 19 / 1998$ & $10 / 20 / 2015$ & $6 / 19 / 2010$ & 2370 & -1949 \\
\hline $\begin{array}{l}\text { Tarcevaß } \\
\text { (Erlotinib) }\end{array}$ & 5747498 & $6 / 6 / 1995$ & $11 / 18 / 2004$ & $11 / 8 / 2018$ & $11 / 18 / 2016$ & 3453 & .720 \\
\hline $\begin{array}{c}\text { Thyrogen@ } \\
\text { (thyrotropin alfa) }\end{array}$ & 5240832 & $6 / 20 / 1989$ & $11 / 30 / 1998$ & $8 / 31 / 2010$ & $11 / 30 / 2010$ & 3450 & 91 \\
\hline $\begin{array}{c}\text { TNKase }^{\mathrm{TM}} \\
\text { (tenecteplase) }^{\mathrm{T}}\end{array}$ & 5385732 & $5 / 20 / 1988$ & $6 / 2 / 2000$ & $6 / 2 / 2014$ & $6 / 2 / 2012$ & 4396 & -730 \\
\hline $\begin{array}{c}\text { Tysabrie } \\
\text { (natalizumab) }\end{array}$ & 5840299 & $1 / 25 / 1995$ & $11 / 23 / 2004$ & $4 / 27 / 2017$ & $11 / 23 / 2016$ & 3590 & -155 \\
\hline $\begin{array}{c}\text { Vectibix@ } \\
\text { (Panitumumab) }\end{array}$ & 6235883 & $5 / 5 / 1997$ & $9 / 27 / 2006$ & $5 / 5 / 2017$ & $9 / 27 / 2018$ & 3432 & 510 \\
\hline $\begin{array}{l}\text { Velcade }^{\mathrm{TM}} \\
\text { (bortezomib for } \\
\text { injection) }\end{array}$ & 5780454 & $10 / 28 / 1994$ & $5 / 13 / 2003$ & $5 / 3 / 2017$ & $5 / 13 / 2015$ & 3119 & -721 \\
\hline $\begin{array}{c}\text { Verluma } \\
\text { (Notetumomab) }\end{array}$ & 4897255 & $1 / 14 / 1985$ & $10 / 13 / 1998$ & $8 / 20 / 2010$ & $10 / 13 / 2010$ & 5020 & 54 \\
\hline $\begin{array}{c}\text { Visudyne }^{\mathrm{TM}} \\
\text { (verteporfin for } \\
\text { injection) }\end{array}$ & 5095030 & $1 / 20 / 1987$ & $4 / 12 / 2000$ & $9 / 9 / 2011$ & $4 / 12 / 2012$ & 4831 & 216 \\
\hline $\begin{array}{c}\text { Xigris }{ }^{\mathrm{TM}} \\
\text { (drotrecogin alfa) }^{2}\end{array}$ & RE 37806 & $4 / 9 / 1986$ & $11 / 21 / 2001$ & $11 / 21 / 2015$ & $11 / 21 / 2013$ & 5705 & .730 \\
\hline $\begin{array}{c}\text { Xolair@ } \\
\text { (omalizumab) }\end{array}$ & 6267958 & $3 / 14 / 1996$ & $6 / 20 / 2003$ & $6 / 20 / 2017$ & $6 / 20 / 2015$ & 2654 & -731 \\
\hline $\begin{array}{c}\text { Zenapax } \\
\text { (Daclizumab) }\end{array}$ & 5530101 & $12 / 28 / 1988$ & $10 / 12 / 1997$ & $6 / 25 / 2013$ & $10 / 12 / 2009$ & 3210 & -1352 \\
\hline $\begin{array}{c}\text { Zevalin }^{\mathrm{TM}} \\
\text { (ibritumomab } \\
\text { tiuxetan) }\end{array}$ & 5776456 & $11 / 13 / 1992$ & $2 / 19 / 2002$ & $2 / 19 / 2016$ & $2 / 19 / 2014$ & 3385 & -725 \\
\hline Average & & & & & & 3728.35 & -326.95 \\
\hline
\end{tabular}


